\title{
Proteomic investigation on bio-corona of Au, Ag and Fe nanoparticles for the discovery of triple negative breast cancer serum protein biomarkers
}

Maríadel Pilar Chantada-Vázquez ${ }^{\mathrm{a}}$, Antonio Castro López ${ }^{\mathrm{b}}$, María García Vence ${ }^{\mathrm{c}}$, Sergio Vázquez-Estévez $^{\mathrm{d}}$, Benigno Acea-Nebrile ${ }^{\mathrm{e}}$, David G. Calatayud ${ }^{\mathrm{f}}$, Teresa Jardiel ${ }^{\mathrm{f}}$, Susana B. Bravo ${ }^{c}$, Cristina Núñez ${ }^{\mathrm{a}}$

${ }^{a}$ Research Unit, Hospital Universitario Lucus Augusti (HULA), Servizo Galego de Saúde (SERGAS), 27002 Lugo, Spain

${ }^{\mathrm{b}}$ Breast Unit, Hospital Universitario Lucus Augusti (HULA), Servizo Galego de Saúde (SERGAS), 27002 Lugo, Spain

${ }^{c}$ Proteomic Unit, Instituto de Investigaciones Sanitarias-IDIS, Complejo Hospitalario Universitario de Santiago de Compostela (CHUS), 15706 Santiago de Compostela, Spain

${ }^{\mathrm{d}}$ Oncology Division, Hospital Universitario Lucus Augusti (HULA), Servizo Galego de Saúde (SERGAS), 27002 Lugo, Spain

${ }^{\mathrm{e}}$ Department of Surgery, Breast Unit, Complexo Hospitalario Universitario A Coruña (CHUAC), SERGAS, A Coruña, Spain

${ }^{\mathrm{f}}$ Department of Electroceramics, Instituto de Cerámica y Vidrio-CSIC, Kelsen 5, Campus de Cantoblanco, 28049 Madrid, Spain

\section{Highlights}

- Interaction of AuNPs, AgNPs and MNPs with human serum formed a protein corona.

- Methods DDA for the qualitative analysis of the protein coronas.

- SWATH-MS for the quantitative analysis of the protein coronas.

- The analysis of the protein coronas allowed the identification of novel biomarkers of TNBC.

- Role of different protein biomarkers in the diagnosis of TNBC. 
M. del Pilar Chantada-Vázquez, A. C. López, M. G. Vence, S. Vázquez-Estévez, B. Acea-Nebril, D.

G. Calatayud, T. Jardiel, S. B. Bravo and C. Núñez, J. Proteomics, 2020, 212, 103581. DOI:

10.1016/j.jprot.2019.103581

\section{Abstract}

Nowadays, there are no targeted therapeutic modalities for triple negative breast cancer (TNBC). This disease is associated with poor prognosis and worst clinical outcome because of the aggressive nature of the tumor, delayed diagnosis, and non-specific symptoms in the early stages. Therefore, identification of novel specific TNBC serum biomarkers for screening and therapeutic purposes remains an urgent clinical requirement.

New user-friendly and cheap methods for biomarker identification are needed, and nanotechnology offers new opportunities. When dispersed in blood, nanoparticles (NPs) are covered by a protein shell termed "protein corona" (PC). While alterations in protein patterns are challeging to detect by conventional blood analyses, PC acts as a "nanoconcentrator" of serum proteins with affinity for NPs' surface. So, the characterization of PC could allow the detection of otherwise undetectable changes in protein concentration at an early stage of the disease or after chemotherapy or surgery.

To explore this research idea, serum samples from 8 triple negative breast cancer (TNBC) patients and 8 patients without malignancy were allowed to interact with gold nanoparticles (AuNPs: $10.02 \pm 0.91 \mathrm{~nm}$ ), silver nanoparticles (AgNPs: $9.73 \pm 1.70 \mathrm{~nm}$ ) and magnetic nanoparticles (MNPs: $(9.30 \pm 0.67 \mathrm{~nm})$. Here, in order to identify biomarker candidates in serum of TNBC patients, these nanomaterials were combined with electrophoretic separation (SDS-PAGE) to performed qualitative and quantitative comparisons of the serum proteomes of TNBC patients $(n=8)$ and healthy controls $(n=$ 8) by liquid chromatography tandem-mass spectrometry (LC-MS/MS) analysis. The results were validated through a sequential window acquisition of all theoretical mass spectra (SWATH) analysis, performed in total serum samples (patients and controls) using this approach as a multiple reaction monitoring (MRM) analysis.

\section{Significance}

It is well known that several proteins presented in human serum are important biomarkers for the diagnosis or prognosis of different diseases, as triple negative breast cancer (TNBC). Determining how nanomaterials as gold nanoparticles (AuNPs: $10.02 \pm 0.91 \mathrm{~nm}$ ), silver nanoparticles (AgNPs: $9.73 \pm 1.70 \mathrm{~nm}$ ) and magnetic nanoparticles (MNPs: $(9.30 \pm 0.67 \mathrm{~nm})$ interact with human serum will assist not only in understanding their effects on the biological system (biocompability and toxicity), but also to obtain information for developing novel nanomaterials with high specificity and selectivity towards proteins with an important biological function (prognostic and diagnostic protein biomarkers).

\section{Introduction}

Breast cancer $(\mathrm{BC})$ is the most frequently diagnosed cancer and the leading cause of cancer death in women worldwide, accounting for $23 \%$ of total new cancer cases [1]].

Mainly, triple negative breast cancer (TNBC) is a heterogeneous disease that is characterized by a lack of estrogen receptor/progesterone receptor (ER/PgR) expression 
M. del Pilar Chantada-Vázquez, A. C. López, M. G. Vence, S. Vázquez-Estévez, B. Acea-Nebril, D. G. Calatayud, T. Jardiel, S. B. Bravo and C. Núñez, J. Proteomics, 2020, 212, 103581. DOI:

10.1016/j.jprot.2019.103581

and absence of human epidermal growth factor receptor 2 (HER2) overexpression or amplification. This subgroup accounts for $12-15 \%$ of all types of breast cancer and exhibits a distinct molecular profile, clinical behavior, and response to therapy [2]. Notably, triple negative tumors are usually high grade and exhibit increased aggressiveness, poor prognosis, and worst clinical outcome [3]. Because hormonal (tamoxifen) and HER2-directed (trastuzumab) therapies are not effective, TNBC patients are managed with standard chemotherapy; however, a high rate of local and systemic relapse is frequently associated with treatment. Unfortunately, no useful biomarkers neither targeted therapeutic modalities exist for this breast cancer subtype [4].

It is well known that proteins secreted from tumor tissues have a higher likelihood of reaching the systemic circulation and may, therefore, serve as potential biomarkers for early detection [5]. Serum proteomics is a valuable tool that can facilitate comprehensive and systematic elucidation of the serum proteome under both healthy and disease conditions as well as identification of serum protein markers used for disease diagnosis and prognosis, particularly for identifying breast cancer-specific markers [5] .

Current proteomic technologies that promote large-scale sample screening and facilitate the identification of proteins associated with disease and treatment are developing rapidly []. Mass spectrometry (MS), a powerful proteomics tool, has evolved to a highthroughput level, allowing rapid and accurate analysis of several thousand proteins in a single study [7]. Several studies have addressed the possibility of applying MS proteome analysis to diagnostics of TNBC, revealing protein patterns specific for patients with TNBC at either early or late clinical stages []. The peptide markers identified with differentiating patterns include glycolytic enzymes (as for example MDH2, PGK1, TKT, Aldolase1), cytokeratins (CK7, 8, 9, 14, 17, 19), further structure proteins (vimentin, fibronectin, L-plastin), for NME1-NME2, lactoferrin, and members of the Annexin family, among others [9].

SWATH-MS is an emerging technique that combines deep proteome coverage capabilities with quantitative consistency and accuracy [10]. Mainly, SWATH-MS analysis offers several advantages, including high reproducibility and reliability of quantitative information, in discovery proteomics [11]. Furthermore, SWATH-MS methods can be interchanged to MRM approaches focused on the validated biomarkers. Therefore, SWATH-MS is an important tool not only for the biomarker discovery but also for the development of preliminary validation studies [12].

However, currently available proteomic tests detect only a tiny fraction of potential biomarkers due to their deficient concentration in biofluids, in addition to the 'swamping' effect, caused by non-specific highly abundant molecules. The issue of signal-to-noise exceeds the current capability of proteomic analysis and therefore limits the diagnostic information that can be obtained [13].

To overcome these challenges, several approaches have been developed, comprising depletion of high-abundance proteins that mask less abundant proteins $[14,15]$, chromatographic or electrophoretic sample prefractionation, to decrease complexity before mass spectrometric analyses [16,17], and direct isolation of preferred proteins [18]. Nevertheless, none of the methods can provide a standard solution to biomarker discovery 
M. del Pilar Chantada-Vázquez, A. C. López, M. G. Vence, S. Vázquez-Estévez, B. Acea-Nebril, D. G. Calatayud, T. Jardiel, S. B. Bravo and C. Núñez, J. Proteomics, 2020, 212, 103581. DOI:

10.1016/j.jprot.2019.103581

or can give a reproducible diagnostic platform for establishing biomarker guides. In this way, one promising way taken is the use of nanoscale materials [19].

Nanotechnology-based platforms hold great promise in addressing the above fundamental and technical issues of biomarker discovery to overcome persistent deficiencies of conventional methods. Currently, it is well known that the surfaces of nanoparticles (NPs) are rapidly covered by different types of biomolecules when they contact biological media called protein corona (PC) [20].

The protein composition and content in the corona depend on several parameters, including: i) physicochemical properties of the NPs (i.e. composition, size, shape, curvature, surface chemistry and surface charge, hydrophobicity/hydrophilicity) [21,22]; ii) characteristics of biological media (i.e. protein source, and temperature) [23, 24$]$ ); iii) incubation time [25].

Notably, the composition of the protein corona varies among healthy individuals, as well as among patients with various diseases/medical conditions. Thus, the same NPs may have different protein coronas in different individuals. These alterations are often small and challenging to be detected by conventional blood analyses.

On the other side, the protein corona can act as a "nano-concentrator" [다 of those serum proteins with affinity for the NP surface. Therefore, characterization of protein corona could allow detecting minor changes in protein concentration at the very early stages of disease development or even after chemotherapy or surgery (i.e., when an alteration in circulating level of proteins could be undetectable by blood tests).

Keeping in mind that each disease is characterized by different plasma/serum proteomes, inducing the formation of different PCs on the same nanomaterial, M. Mahmoudi, et al. introduced the novel concept of "personalized protein corona" (PPC) [27]. More specifically, depending on the type, period and severity of the disease (which determines the serum/plasma alterations), each patient may have a personalized protein corona.

In the present study, gold nanoparticles (AuNPs: $10.02 \pm 0.91 \mathrm{~nm}$ ), silver nanoparticles (AgNPs: $9.73 \pm 1.70 \mathrm{~nm}$ ) and magnetic nanoparticles (MNPs: $(9.30 \pm 0.67 \mathrm{~nm})$ were used to pre-concentrate and separate proteins from sera samples of eight patients with TNBC as well as from eight healthy people. For protein biomarkers identification and quantification, the proteome map changes between both groups were detected using a proteomic approach based on electrophoretic separation (SDS-PAGE) and mass spectrometry (nLC-MS/MS).

\section{Materials and methods}

\subsection{Chemicals and reagents}

All reagents and solvents used were HPLC-grade or higher. Sodium citrate tribasic dihydrate, tannic acid, silver nitrate, ammonium hydroxide,

iron(III) chloride hexahydrate and iron(II) sulfate heptahydrate, sodium borohydride $\left(\mathrm{NaBH}_{4}\right)$, trypsin, trifluoroacetic acid, DL-Dithiothreitol (DTT), Iodoacetamide (IAA), 
M. del Pilar Chantada-Vázquez, A. C. López, M. G. Vence, S. Vázquez-Estévez, B. Acea-Nebril, D. G. Calatayud, T. Jardiel, S. B. Bravo and C. Núñez, J. Proteomics, 2020, 212, 103581. DOI:

10.1016/j.jprot.2019.103581

acrylamide/bis-acrylamide $30 \%$ solution (37.5:1), Glycerol 86-88\%, Tris-base, Coomassie Brilliant Blue R250 (CBB), sodium carbonate, and the Sigma Marker wide range 6.5-200 kDa were purchased from Sigma-Aldrich (St. Louis, MO, USA). Sodium dodecyl sulfate (SDS) and formaldehyde were purchased from Panreac (Barcelona, Spain). $\beta$-mercaptoethanol was purchased from Merck (Hohen-Brunn, Germany), and bromophenol-blue was purchased from Riedel-de Haen (Seelze, Germany). Hydrogen tetrachloroaurate (III) hydrate $(99.9 \%-\mathrm{Au})(49 \% \mathrm{Au})$ at $10 \% \mathrm{w} / \mathrm{v}$ was purchased from Strem Chemicals (Newburyport, MA, USA). Ammonium bicarbonate (ambic) and formic acid were purchased from Fluka (Steinheim, Germany).

\subsection{Instrumentation}

Microscopic characterizations of AuNPs, AgNPs, and MNPs were performed by transmission electron microscopy (TEM) using a Jeol JEM 1011 microscope. Samples for TEM were prepared by pipetting a drop of the colloidal dispersion onto an ultrathin carbon-coated copper grid and allowing the solvent to evaporate. AuNPs, AgNPs and MNPs $\zeta$-potentials were measured at $25^{\circ} \mathrm{C}$ before and after protein corona formation using a Malvern Zetasizer Nano ZS instrument. For $\zeta$-potential measurements samples were diluted in $1 \mathrm{~mL}$ milli-Q water and placed in Zetasizer disposable cuvettes. A minimum of 3 measurements per sample were made.

Power Pac Basic power supply from Bio-Rad (CA, USA) was used for sodium dodecyl sulfate- polyacrylamide gel electrophoresis (SDS-PAGE) protein separation. Protein quantification was accomplished by measuring the absorbance at $280 \mathrm{~nm}$ with the use of a Qubit 4 Quantitation Starter Kit from Thermo Fisher Scientific. Gel image acquisition was carried out with a UVP PhotoDoc-It ${ }^{\mathrm{TM}}$ Imaging System from Analytik Jena.

\subsection{Synthesis of inorganic nanoparticles}

\subsubsection{Synthesis of citrate-gold nanoparticles $(10.02 \pm 0.91 \mathrm{~nm})$}

Gold nanoparticles (AuNPs) were synthesized by the citrate reduction method in aqueous solution [28]. Briefly, $60 \mathrm{ml}$ of sodium citrate tribasic solution $(0.075 \% \mathrm{w} / \mathrm{v})$ was heated to $100{ }^{\circ} \mathrm{C}$, and then gold was added as $54 \mu \mathrm{L}$ of $10 \% \mathrm{w} / \mathrm{v}$ of hydrogen tetrachloroaurate (III) hydrate solution. The reaction mixture was kept under reflux until a deep red color was detected. The solution of nanoparticles is chilled at room temperature and stored at 4 ${ }^{\circ} \mathrm{C}$ for a maximum of one month.

\subsubsection{Synthesis of citrate-silver nanoparticles $(9.73 \pm 1.70 \mathrm{~nm})$}

Silver nanoparticles (AgNPs) were synthesized by the citrate reduction method in aqueous solution by the method reported by V. Puntes et al. [29]. A $100 \mathrm{~mL}$ volume of an aqueous solution containing sodium citrate (SC) $(5 \mathrm{mM})$ and tannic acid (TA) $(0.025 \mathrm{mM})$ was prepared and heated with a heating mantle in a three-neck roundbottomed flask for $15 \mathrm{~min}$ under vigorous stirring. A condenser was used to prevent the evaporation of the solvent. After boiling had commenced, $1 \mathrm{~mL}$ of $\mathrm{AgNO}_{3}(25 \mathrm{mM})$ was injected into this solution. The solution became bright yellow immediately. Resultant Ag NPs were purified by centrifugation at $18,000 \times g$ to remove the excess of TA and further redispersed in Milli-Q-water before sample characterization. 
M. del Pilar Chantada-Vázquez, A. C. López, M. G. Vence, S. Vázquez-Estévez, B. Acea-Nebril, D.

G. Calatayud, T. Jardiel, S. B. Bravo and C. Núñez, J. Proteomics, 2020, 212, 103581. DOI:

10.1016/j.jprot.2019.103581

\subsubsection{Synthesis of $\mathrm{Fe}_{3} \mathrm{O}_{4}$ magnetic nanoparticles $(9.30 \pm 0.67 \mathrm{~nm})$}

The synthesis of magnetic nanoparticles was performed according to a previously described procedure [30]. Briefly, $6 \mathrm{~mL}$ of concentrated ammonium hydroxide and $4 \mathrm{~mL}$ of water saturated with $\mathrm{N}_{2}$ were mixed in a round-bottom flask under an inert atmosphere. Subsequently, in another vessel, $1 \mathrm{~g}$ of $\mathrm{FeCl}_{3} .6 \mathrm{H}_{2} \mathrm{O}$ and $0.25-0.5 \mathrm{~g}$ of $\mathrm{FeSO}_{4} .7 \mathrm{H}_{2} \mathrm{O}$ were dissolved in $10 \mathrm{~mL}$ of water saturated with $\mathrm{N}_{2}$. After mixing both solutions, the system was kept under constant stirring for $80 \mathrm{~min}$ at $80{ }^{\circ} \mathrm{C}$. The final reaction product was washed three times with deionized water and magnetically separated for $24 \mathrm{~h}$ at room temperature.

\subsection{Sample resources}

Venous blood samples were obtained from eight females with triple negative breast cancer (TNBC) and eight disease-free individuals with the use of VACUETTE® Serum Clot Activator Tubes $(10 \mathrm{~mL})$. The collected blood samples were allowed to clot for $15 \mathrm{~min}$ and then centrifuged for $5 \mathrm{~min}$ at $4^{\circ} \mathrm{C}$ and $1,800 \times \mathrm{g}$. Sera were transferred into clean plastic tubes $(1 \mathrm{~mL})$ and immediately frozen at $-80^{\circ} \mathrm{C}$ at Research Unit, Hospital Universitario Lucus Augusti (HULA). Clinical features of TNBC tumors, including tumor size, histology, receptor status, clinical stage, and nodal status, are summarized in Table 1.

Table 1. Clinical features of triple negative breast cancer tumors.

\begin{tabular}{|c|c|c|}
\hline Characteristics & & Number \\
\hline Patients & & 8 \\
\hline \multirow[t]{3}{*}{ Age (years) } & $<40$ & 1 \\
\hline & $40-70$ & 4 \\
\hline & $>70$ & 3 \\
\hline \multirow[t]{3}{*}{ Tumor size $(\mathrm{cm})$} & $<2$ & 3 \\
\hline & $2-5$ & 4 \\
\hline & $>5$ & 1 \\
\hline Histological types & Ductal invasive carcinoma & 8 \\
\hline Receptor status & Triple negative & 8 \\
\hline \multirow[t]{3}{*}{ Clinical stage } & I & 1 \\
\hline & II & 4 \\
\hline & III & 3 \\
\hline \multirow[t]{2}{*}{ Nodal status } & No & 7 \\
\hline & N1 & 1 \\
\hline
\end{tabular}


M. del Pilar Chantada-Vázquez, A. C. López, M. G. Vence, S. Vázquez-Estévez, B. Acea-Nebril, D.

G. Calatayud, T. Jardiel, S. B. Bravo and C. Núñez, J. Proteomics, 2020, 212, 103581. DOI:

10.1016/j.jprot.2019.103581

\subsection{Sample preparation}

\subsubsection{Optimization of protein corona formation in serum using magnetic nanoparticles}

A series of serum sample aliquots were used for checking the effects of sample $\mathrm{pH}$ and temperature on the high-abundance proteins depletion using DTT, MNP/protein ratios, and $\mathrm{pH}$ of the medium on the washing steps.

\subsubsection{Depletion of multiple high abundant proteins}

Human serum aliquots (x8) were filtered with Miller-GP® Filter Unit (Millipore) with a size of $0.22 \mu \mathrm{m}$. Four aliquots of human serum $(30 \mu \mathrm{L})$ were depleted with dithiothreitol (DTT) according to the protocol described by Warder el al. [31,32]. Briefly, fresh DTT $500 \mathrm{mM}(3.3 \mu \mathrm{L})$ in milli-Q water was mixed with $30 \mu \mathrm{L}$ of human serum and vortex quickly. Samples were then incubated at room temperature until a viscous white precipitate persisted $(60 \mathrm{~min})$, followed by centrifugation at $18,840 \times \mathrm{g}$ for $20 \mathrm{~min}$. Supernatants were transferred to a clean tube before the protein alkylation and nanoparticles (NPs) fractionation.

To evaluate the effects of sample $\mathrm{pH}$ and temperature on the high-abundance proteins depletion with DTT, four aliquots of human serum $(30 \mu \mathrm{L})$ were depleted with dithiothreitol (DTT) following a modification of the protocol previously published by Arruda et al. [33]. Four aliquots of $30 \mu \mathrm{L}$ of human serum were mixed fresh DTT $500 \mathrm{mM}$ $(3.3 \mu \mathrm{L})$ in ambic $\left.\left(12.5 \mathrm{mmol} \mathrm{L}^{-1}\right)\right]$ and vortexed. Samples were incubated for $60 \mathrm{~min}$ at $37^{\circ} \mathrm{C}$, centrifuged at $13,000 \times g$ for $40 \mathrm{~min}$ to separate supernatants to be alkylated and fractionated with nanoparticles (NPs).

\subsubsection{NPs protein alkylation and fractionation}

After protein depletion, the reduced $\mathrm{SH}$-groups were alkylated with iodoacetic acid (IAA) for $45 \mathrm{~min}$ at room temperature and protected from light. Volumes of serum reduced and alkylated, were diluted to a final volume of $100 \mu \mathrm{L}$ in Tris- $\mathrm{HCl}\left(0.1 \mathrm{~mol} \mathrm{~L}^{-1}, \mathrm{pH} 5.5\right)$, and mixed with MNPs $(5 \mu \mathrm{g})$ to obtain the following MNP/protein ratios: 1:1, 1:2, 1:4, 1:10. Then, all NPs-serum solutions were incubated at $25{ }^{\circ} \mathrm{C}$ with shaking $(300 \mathrm{rpm})$ in a thermostatic bath for $30 \mathrm{~min}$ and then pellets were harvested by centrifugation at $20,186 \times g$ for $30 \mathrm{~min}$. To evaluate the effects of sample $\mathrm{pH}$ on the stabilization of the protein corona in the washing steps, a fraction of pellets were washed (x3) with $50 \mu \mathrm{L}$ of Tris- $\mathrm{HCl}\left(0.1 \mathrm{~mol} \mathrm{~L}^{-1}, \mathrm{pH} 5.5\right)$ and another fraction with $50 \mu \mathrm{L}$ of milli-Q water (x3). In both cases, pellets were harvested again by centrifugation at $20,186 \times g$ for $30 \mathrm{~min}$ to remove unbound proteins.

\subsubsection{Incubation of nanoparticles with serum samples}

Serum aliquots $(x 2)$ belonging to the eight disease-free individuals and eight triple negative breast cancer patients were depleted with dithiothreitol (DTT) following the method of Warder el al. [33,34]. After that, the reduced SH-groups were alkylated with iodoacetic acid (IAA) at room temperature (45 min in the dark). 
M. del Pilar Chantada-Vázquez, A. C. López, M. G. Vence, S. Vázquez-Estévez, B. Acea-Nebril, D. G. Calatayud, T. Jardiel, S. B. Bravo and C. Núñez, J. Proteomics, 2020, 212, 103581. DOI:

10.1016/j.jprot.2019.103581

After protein reduction and alkylation, serum aliquots $(x 2)$ belonging to the eight diseasefree individuals and eight triple negative breast cancer patients were incubated with AuNPs $(10.02 \pm 0.91 \mathrm{~nm})$ and AgNPs $(9.73 \pm 1.70 \mathrm{~nm})$ (4 aliquots per individual, 2 with each nanoparticle type) following the method described by C. Núñez et al. [34]. Briefly, $75 \mu \mathrm{L}$ of AuNPs $(10.02 \pm 0.91 \mathrm{~nm})$ and $75 \mu \mathrm{L}$ of AgNPs $(9.73 \pm 1.70 \mathrm{~nm})$ were added to each different serum aliquots $(\times 2)$ belonging to the eight disease-free individuals and eight triple negative breast cancer patients (4 aliquots per individual, 2 with each nanoparticle type), followed by the addition of $40 \mu \mathrm{L}$ of citrate/citric acid buffer to a final $\mathrm{pH}$ of 5.8. Then, all NPs-serum solutions were incubated at $37{ }^{\circ} \mathrm{C}$ with shaking in a thermostatic bath for $30 \mathrm{~min}$. Pellets were harvested by centrifugation at $18,840 \times g$ for $30 \mathrm{~min}$. In all cases, pellets containing proteins bound to nanoparticles were washed three times with $25 \mu \mathrm{L}$ citrate/citric acid buffer and harvested again by centrifugation at $18,840 \times g$ for $30 \mathrm{~min}$ to remove unbound proteins.

In the particular case of magnetic nanoparticles, each different reduced and alkylated serum aliquots $(x 2)$ from disease-free individuals $(n=8)$ and negative breast cancer patients $(\mathrm{n}=8)$ were incubated (shaking at $\left.300 \mathrm{rpm}, 25^{\circ} \mathrm{C}, 30 \mathrm{~min}\right)$ with $5 \mu \mathrm{L}$ of MNPs $(9.30 \pm 0.67 \mathrm{~nm})$ after the addition of $87 \mu \mathrm{L}$ of Tris- $\mathrm{HCl}\left(0.1 \mathrm{~mol} \mathrm{~L}^{-1}, \mathrm{pH} 5.5\right)$.

After centrifuging $(15,000 \times g, 30 \mathrm{~min})$, pellets were separated and washed $(\mathrm{x} 3)$ with $50 \mu \mathrm{L}$ of Tris- $\mathrm{HCl}\left(0.1 \mathrm{~mol} \mathrm{~L}^{-1}, \mathrm{pH} 5.5\right)$ and centrifuged again $(20,186 \times g, 30 \mathrm{~min})$.

\subsubsection{Gel electrophoresis}

After that, pellets were reconstituted in $10 \mu \mathrm{L}$ of a buffer with $0.2 \mathrm{M}$ Tris- $\mathrm{HCl}, 2 \% \mathrm{w} / \mathrm{v}$ SDS and $20 \% \mathrm{v} / \mathrm{v}$ glycerol. This $10 \mu \mathrm{L}$ was mixed with $4 \mu \mathrm{L}$ of SDS-PAGE loading buffer $(10 \% \mathrm{w} / \mathrm{v}$ SDS, Tris-Base $40 \mathrm{mM}, \mathrm{pH} 6.8,50 \% \mathrm{v} / \mathrm{v}$ glycerol, $0.1 \% \mathrm{v} / \mathrm{v}$ bromophenol blue, $10 \% \mathrm{v} / \mathrm{v} \beta$-mercaptoethanol) in a final volume of $20 \mu \mathrm{L}$. Then, all samples were denatured by heating at $100^{\circ} \mathrm{C}$ for $5 \mathrm{~min}$ and loaded into a $10 \%$ acrylamide/bis-acrylamide, stacking gel/12.5\% acrylamide/bis-acrylamide running gel, of $1 \mathrm{~mm}$ thickness, and separated at $180 \mathrm{~V}$ (constant voltage) for $120 \mathrm{~min}$. After electrophoresis, the gel was fixed for 30 minutes with $40 \%(\mathrm{v} / \mathrm{v})$ ethanol and $10 \%(\mathrm{v} / \mathrm{v})$ acetic acid and then stained overnight with Colloidal Coomassie Blue [35]. Gels were rinsed with distilled water and a $0.5 \mathrm{M}$ sodium chloride solution until a clear background was observed. Gel imaging was carried out with a UVP PhotoDoc-It ${ }^{\mathrm{TM}}$ Imaging System.

\subsubsection{In-gel protein digestion}

Protein bands were excised manually and transferred to $2.5-\mathrm{mL}$ Lo-Bind tubes, and then washed twice with water and with $50 \%$ (v/v) acetonitrile $/ 25 \mathrm{mM}$ ammonium bicarbonate (ambic) until the blue color disappeared.

Before the trypsin digestion, gel spots were washed with $25 \mathrm{mM}$ ambic and dehydrated with acetonitrile. Then, $30 \mu \mathrm{L}$ of trypsin $\left(20 \mathrm{ng} \mu \mathrm{L}^{-1}\right.$ in $12.5 \mathrm{mM}$ ambic/2\% $(\mathrm{v} / \mathrm{v})$ acetonitrile) was added to the gel spots and incubated for $60 \mathrm{~min}$ at $0^{\circ} \mathrm{C}$.

After this time, gel spots were inspected, trypsin solution not absorbed into the gel was removed, and the gels were covered with $100 \mu \mathrm{L}$ of $12.5 \mathrm{mM}$ ambic. Samples were incubated for $12 \mathrm{~h}$ at $37^{\circ} \mathrm{C}$. Then $50 \mu \mathrm{L}$ of $5 \%(\mathrm{v} / \mathrm{v})$ formic acid was added, and the 
M. del Pilar Chantada-Vázquez, A. C. López, M. G. Vence, S. Vázquez-Estévez, B. Acea-Nebril, D. G. Calatayud, T. Jardiel, S. B. Bravo and C. Núñez, J. Proteomics, 2020, 212, 103581. DOI:

10.1016/j.jprot.2019.103581

supernatant was transferred to a new Lo-Bind tube and the peptides were further extracted from the gel twice with $50 \%(\mathrm{v} / \mathrm{v})$ acetonitrile/0.1\% (v/v) trifluoroacetic acid (TFA) $(x 3)$ and acetonitrile $(\mathrm{ACN})(x 1)$. Samples were dried-down and stored at $-20{ }^{\circ} \mathrm{C}[36]$.

\subsection{Protein identification by mass spectrometry (LC-MS/MS) and data analysis}

Digested peptides of each sample were separated using Reverse Phase Chromatography. The gradient was developed using a micro liquid chromatography system (Eksigent Technologies nanoLC 400, SCIEX) coupled to high-speed Triple TOF 6600 mass spectrometer (SCIEX) with a microflow source. The analytical column used was a silicabased reversed phase column Chrom XP C18 $150 \times 0.30 \mathrm{~mm}, 3 \mathrm{~mm}$ particle size and 120 $\AA$ pore size (Eksigen, SCIEX). The trap column was a YMC-TRIART C18 (YMC Technologies, Teknokroma with a $3 \mathrm{~mm}$ particle size and $120 \AA$ pore size, switched online with the analytical column. The loading pump delivered a solution of $0.1 \%$ formic acid in water at $10 \mu \mathrm{L} / \mathrm{min}$. The micro-pump provided a flow-rate of $5 \mu \mathrm{L} / \mathrm{min}$ and was operated under gradient elution conditions, using $0.1 \%$ formic acid in water as mobile phase $\mathrm{A}$, and $0.1 \%$ formic acid in acetonitrile as mobile phase B. Peptides were separated using a 25 minutes gradient ranging from $2 \%$ to $90 \%$ mobile phase B (mobile phase A: $2 \%$ acetonitrile, $0.1 \%$ formic acid; mobile phase $\mathrm{B}: 100 \%$ acetonitrile, $0.1 \%$ formic acid). The injection volume was $4 \mu \mathrm{L}$.

Data acquisition was carried out in a TripleTOF 6600 System (SCIEX, Foster City, CA) using a Data dependent workflow. Source and interface conditions were as follows: ion spray voltage floating (ISVF) $5500 \mathrm{~V}$, curtain gas (CUR) 25, collision energy (CE) 10 and ion source gas 1 (GS1) 25. The instrument was operated with Analyst TF 1.7.1 software (SCIEX, USA). Switching criteria were set to ions greater than mass to charge ratio $(\mathrm{m} / \mathrm{z}) 350$ and smaller than $\mathrm{m} / \mathrm{z} 1400$ with a charge state of $2-5$, mass tolerance $250 \mathrm{ppm}$ and an abundance threshold of more than 200 counts (cps). Former target ions were excluded for $15 \mathrm{~s}$. The instrument was automatically calibrated every 4 hours using as external calibrant tryptic peptides from PepcalMix (Sciex).

After MS/MS analysis, data files were processed using ProteinPilot ${ }^{\mathrm{TM}}$ 5.0.1 software from Sciex, which uses the algorithm Paragon ${ }^{\mathrm{TM}}$ for database search and Progroup ${ }^{\mathrm{TM}}$ for data grouping. Data were searched using a Human-specific UniProt database. False discovery rate was performed using a non-linear fitting method displaying only those results that reported a $1 \%$ Global false discovery rate or better $[\underline{37}, \underline{38}]$.

\subsection{Protein quantification by SWATH (Sequential Window Acquisition of all Theoretical Mass Spectra) \\ 2.7.1. Creation of the spectral library}

To construct the MS/MS spectral libraries, the peptide solutions were analyzed by a shotgun data-dependent acquisition (DDA) approach by micro-LC-MS/MS. To get a good representation of the peptides and proteins present in all samples, pooled vials of samples from each group (control and triple negative breast cancer patients) were prepared using equal mixtures of the original samples. $4 \mu \mathrm{L}(4 \mathrm{mg})$ of each pool was separated into a micro-LC system Ekspert nLC425 (Eksigen. Dublin. CA. USA) using a column Chrom XP C18 $150 \times 0.30 \mathrm{~mm} .3 \mathrm{~mm}$ particle size and $120 \AA ̊$ pore size (Eksigent, 
M. del Pilar Chantada-Vázquez, A. C. López, M. G. Vence, S. Vázquez-Estévez, B. Acea-Nebril, D. G. Calatayud, T. Jardiel, S. B. Bravo and C. Núñez, J. Proteomics, 2020, 212, 103581. DOI:

10.1016/j.jprot.2019.103581

Sciex) at a flow rate of $5 \mu \mathrm{L} / \mathrm{min}$. Water and $\mathrm{ACN}$, both containing $0.1 \%$ formic acid, were used as solvents A and B, respectively. The gradient run consisted of 5-95\% B for $30 \mathrm{~min}, 5 \mathrm{~min}$ at $90 \% \mathrm{~B}$ and finally $5 \mathrm{~min}$ at $5 \% \mathrm{~B}$ for column equilibration, for a total run time of $40 \mathrm{~min}$. When the peptides eluted, they were directly injected into a hybrid quadrupole-TOF mass spectrometer Triple TOF 6600 (Sciex, Redwood City. CA. USA) operated with a data-dependent acquisition system in positive ion mode. A Micro source (Sciex) was used for the interface between microLC and MS, with an application of $2600 \mathrm{~V}$ voltage. The acquisition mode consisted of a $250 \mathrm{~ms}$ survey MS scan from 400 to $1250 \mathrm{~m} / \mathrm{z}$ followed by an MS/MS scan from 100 to $1500 \mathrm{~m} / \mathrm{z}$ (25 ms acquisition time) of the top 65 precursor ions from the survey scan, for a total cycle time of $2.8 \mathrm{~s}$. The fragmented precursors were then added to a dynamic exclusion list for $15 \mathrm{~s}$; any singly charged ions were excluded from the MS/MS analysis.

The peptide and protein identifications were performed using Protein Pilot software (version 5.0.1. Sciex) with a Data were searched using a Human-specific UniProt database, specifying iodoacetamide as Cys alkylation. The false discovery rate (FDR) was set to 1 for both peptides and proteins. The MS/MS spectra of the identified peptides were then used to generate the spectral library for SWATH peak extraction using the add-in for PeakView Software (version 2.2. Sciex) MS/MSALL with SWATH Acquisition MicroApp (version 2.0. Sciex). Peptides with a confidence score above 99\% (as obtained from Protein Pilot database search) were included in the spectral library).

\subsubsection{Relative quantification by SWATH acquisition}

SWATH-MS (Sequential Window Acquisition of all Theoretical Mass Spectra) acquisition was performed on a TripleTOF® 6600 LC-MS/MS system (Sciex). Samples from control and triple negative breast cancer patients were analyzed using dataindependent acquisition (DIA) method (30 total samples). Each sample ( $4 \mu \mathrm{L}$ (from a $\mathrm{mg} / \mathrm{ml}$ solution) was analyzed using the LC-MS equipment and LC gradient described above for building the spectral library but instead using the SWATH-MS acquisition method. The method consisted of repeating a cycle that consisted of the acquisition of 65 TOF MS/MS scans (400-1500 m/z, high sensitivity mode, $50 \mathrm{~ms}$ acquisition time) of overlapping sequential precursor isolation windows of variable width $(1 \mathrm{~m} / \mathrm{z}$ overlap) covering the $400-1250 \mathrm{~m} / \mathrm{z}$ mass range with a previous TOF MS scan $(400-1500 \mathrm{~m} / \mathrm{z}$. $50 \mathrm{~ms}$ acquisition time) for each cycle. The total cycle time was $6.3 \mathrm{~s}$. For each sample set, the width of the 100 variable windows was optimized according to the ion density found in the DDA runs using a SWATH variable window calculator worksheet from Sciex.

\subsubsection{Data analysis}

The targeted data extraction of the fragment ion chromatogram traces from the SWATH runs was performed by PeakView (version 2.2) using the SWATH Acquisition MicroApp (version 2.0). This application processed the data using the spectral library created from the shotgun data. Up to ten peptides per protein and seven fragments per peptide were selected, based on signal intensity; any shared and modified peptides were excluded from the processing. Five-minute windows and $30 \mathrm{ppm}$ widths were used to extract the ion chromatograms; SWATH quantitation was attempted for all proteins in the ion library that were identified by ProteinPilot with an FDR below $1 \%$. 
The retention times from the peptides that were selected for each protein were realigned in each run according to the iRT peptides spiked in each sample and eluted along the whole-time axis. The extracted ion chromatograms were then generated for each selected fragment ion; the peak areas for the peptides were obtained by summing the peak areas from the corresponding fragment ions. PeakView computed an FDR and a score for each assigned peptide according to the chromatographic and spectral components; only peptides with an FDR below 1\% were used for protein quantitation. Protein quantitation was calculated by adding the peak areas of the corresponding peptides.

The integrated peak areas (processed, mrkvw files from PeakView) were directly exported to the MarkerView software (Sciex) for relative quantitative analysis. The export will generate three files containing quantitative information about individual ions, the summed intensity of different ions for a particular peptide, and the summed intensity of different peptides for a specific protein. MarkerView has been used for the analysis of SWATH-MS data reported in other proteomics studies $[\underline{39}, \underline{40}]$ because of its dataindependent method of quantitation. MarkerView uses processing algorithms that accurately find chromatographic and spectral peaks direct from the raw SWATH data. Data alignment by MarkerView compensates for minor variations in both mass and retention time values, ensuring that identical compounds in different samples are accurately compared to one another.

To control for possible uneven sample loss across the different samples during the sample preparation process, we performed a global normalization based on the total sum of all the peak areas extracted from all the peptides and transitions across the replicates of each sample. Unsupervised multivariate statistical analysis using principal component analysis (PCA) was performed to compare the data across the samples. The average MS peak area of each protein was derived from the biological replicates of the SWATH-MS of each sample followed by Student's $t$-test analysis using the MarkerView software for comparison among the samples based on the averaged area sums of all the transitions derived for each protein. The $t$-test will indicate how well each variable distinguishes the two groups, reported as a $p$-value. To set of differentially expressed proteins ( $p$ value $<0.05$ ) with a 1.5 fold in- or decrease was selected.

Functional analysis was performed by FunRich open access software (Functional Enrichment analysis tool) for functional enrichment and interaction network analysis (http://funrich.org/index.html).

\subsection{TNBC biomarkers validation}

A SWATH-MS analysis was performed using the same conditions described in Section 2.7. In the validation phase, total serum samples from control and triple negative breast cancer patients previously depleted with DTT were used.

To perform the biomarker validation, the SWATH library was performed using not only serum pools from incubation with the different nanoparticles but also pools of total serum samples. Therefore, we improve our library and perform better protein quantification to achieve biomarker validation. 
M. del Pilar Chantada-Vázquez, A. C. López, M. G. Vence, S. Vázquez-Estévez, B. Acea-Nebril, D. G. Calatayud, T. Jardiel, S. B. Bravo and C. Núñez, J. Proteomics, 2020, 212, 103581. DOI:

10.1016/j.jprot.2019.103581

\section{Results}

Following the synthetic methods described by R. López-Cortés [30], V. Puntes et al. [31] and F. Schüth et al. [32], AuNPs $(10.02 \pm 0.91 \mathrm{~nm})$, AgNPs $(9.73 \pm 1.70 \mathrm{~nm})$ and MNPs $(9.30 \pm 0.67 \mathrm{~nm})$ were successfully obtained, respectively.

The sizes and $\zeta$-potential of AuNPs $(10.02 \pm 0.91 \mathrm{~nm}), \operatorname{AgNPs}(9.73 \pm 1.70 \mathrm{~nm})$ and MNPs $(9.30 \pm 0.67 \mathrm{~nm})$ were examined before and after their incubation with two pools of human blood serum from healthy individuals and triple negative breast cancer patients, following the conditions described in Section 2.5.2.

TEM and $\zeta$-potential measurements after the incubation of AuNPs $(10.02 \pm 0.91 \mathrm{~nm})$, AgNPs $(9.73 \pm 1.70 \mathrm{~nm})$ and MNPs $(9.30 \pm 0.67 \mathrm{~nm})$ with serum demonstrated that, in all cases, the size did not change significantly and the surface charge remained negative (see Figs. S1-S10). Upon serum incubation, the mean particle surface charge of the AuNPs $(10.02 \pm 0.91 \mathrm{~nm})$ increased (became less negative) from $-37.0 \mathrm{mV}$ to $-29.7 \mathrm{mV}$, and the same measurement for the MNPs $(9.30 \pm 0.67 \mathrm{~nm})$ increased from $-30.5 \mathrm{mV}$ to $-29.3 \mathrm{mV}$. However, upon serum incubation the mean particle surface charge of the AgNPs $(9.73 \pm 1.70 \mathrm{~nm}$ ) decreased (became more negative) from $-27.4 \mathrm{mV}$ to $-30.0 \mathrm{mV}$. These results are in agreement with previous studies suggesting that negatively charged NPs do not exclusively interact with positively charged proteins, as electrostatic interactions are not the only driving force behind NP-corona interactions [41, 42]. Interestingly, for AuNPs $(10.02 \pm 0.91 \mathrm{~nm})$ and MNPs $(9.30 \pm 0.67 \mathrm{~nm})$, where the $\zeta$-potential was shifted toward less negative values, it could be suggested preferential interaction with positively charged proteins. The presence of negatively charged proteins can be explained by a sequential model of protein binding, in which positively charged proteins initially bind the NP, followed by negatively charged ones $[\underline{45}, \underline{46}]$.

\subsection{Optimization of parameters for the protein corona formation in serum using MNPS}

As mentioned above, a great number of variables could influence the efficiency of protein adsorption on the MNPs surface [43]. For this reason, three parameters were evaluated: (i) the effects of sample $\mathrm{pH}$ and temperature on the depletion of high-abundance proteins presented in serum using DTT, (ii) MNP/protein ratios; (iii) and $\mathrm{pH}$ of the medium on the washing steps. For this study, shaking and incubation temperature were previously defined as $300 \mathrm{rpm}$ and $25^{\circ} \mathrm{C}$, respectively.

In order to evaluate the effects of sample $\mathrm{pH}$ and temperature on the depletion of highabundance proteins, four human serum samples $(x 2)(30 \mu \mathrm{L})$ were depleted with fresh DTT $500 \mathrm{mM}(3.3 \mu \mathrm{L})$ in milli-Q $\mathrm{H}_{2} \mathrm{O}$ for $60 \mathrm{~min}$ at room temperature (protocol of Warder el al. $[33, \underline{34]})$, and four human serum samples $(x 2)(30 \mu \mathrm{L})$ were depleted with fresh DTT $500 \mathrm{mM}(3.3 \mu \mathrm{L})$ in ambic $\left(12.5 \mathrm{mmol} \mathrm{L}^{-1}\right)$ for $60 \mathrm{~min}$ at $37^{\circ} \mathrm{C}$ (modification of protocol described by Arruda [35]). In both cases, after the incubation and centrifugation, supernatants were transferred to a clean tube before the protein alkylation and nanoparticles (NPs) fractionation. Depletion with fresh DTT $500 \mathrm{mM}$ in milli-Q for $60 \mathrm{~min}$ at room temperature showed more reproducible results (see Fig. S4). 
M. del Pilar Chantada-Vázquez, A. C. López, M. G. Vence, S. Vázquez-Estévez, B. Acea-Nebril, D. G. Calatayud, T. Jardiel, S. B. Bravo and C. Núñez, J. Proteomics, 2020, 212, 103581. DOI:

10.1016/j.jprot.2019.103581

Protein concentration is another critical parameter that may affect the capacity and kinetics of protein adsorption. To investigate the influence of the MNP/protein ratio on the formation of the protein corona, volumes of serum reduced and alkylated $(x 2)$ were mixed with MNPs $(9.30 \pm 0.67 \mathrm{~nm})$, at MNP/protein ratios of $1: 1,1: 2,1: 4$, and 1:10 (see Section 2.5.1). Maintaining the amount of adsorbent (i.e., MNPs) constant and increasing the protein concentration, would be expected to lead to a decrease of available adsorption sites, reducing the efficiency of protein removal [44]. As a compromise between MNPs and protein corona formation, the 1:2 ratio (MNP/protein) was then selected for future experiments (see Fig. S5).

The $\mathrm{pH}$ value is an essential parameter because it influences the charge state of proteins, therefore influencing their interaction with MNPs [45]. To evaluate the effects of sample $\mathrm{pH}$ on the stabilization of the protein corona in the washing steps, a fraction of pellets were washed three times with $50 \mu \mathrm{L}$ Tris- $\mathrm{HCl}\left(0.1 \mathrm{~mol} \mathrm{~L}^{-1}, \mathrm{pH} 5.5\right)$ and another fraction was washed three times with milli-Q water. The first one was selected as the preferred method, because the washes with milli-Q water promoted the destabilization of the protein corona formed around the MNPs, due to the modifications of the $\mathrm{pH}$ (data not shown).

\subsection{Serum fraction preparation and protein corona purification (patients vs. controls)}

Serum aliquots $(x 2)$ belonging to the eight disease-free individuals and serum samples from eight triple negative breast cancer patients were depleted with dithiothreitol (DTT) according to the protocol described by Warder el al. [33, 34]. After that, the reduced SHgroups were alkylated with iodoacetic acid (IAA) for $45 \mathrm{~min}$ at room temperature and protected from light.

After protein reduction and alkylation, serum aliquots $(x 2)$ belonging to the eight diseasefree individuals and eight triple negative breast cancer patients were incubated with AuNPs $(10.02 \pm 0.91 \mathrm{~nm})$, AgNPs $(9.73 \pm 1.70 \mathrm{~nm})$ and MNPs $(9.30 \pm 0.67 \mathrm{~nm})(6$ aliquots per individual, 2 with each nanoparticle type) and further processed as described in Section 2.5.2.

Two protein fractions were thus obtained in each case, one in the supernatant and the second one attached to the surface of each nanoparticles types (protein corona). Then, protein fractions (AuNPs-protein corona, AgNPs-protein corona, MNPs-protein corona) were separately loaded onto a 1D-SDS-PAGE. Proteins were separated and, after staining, gel bands were excised and submitted to the sample incubation described in Section 2.5.4. The resulting peptides were then analyzed by mass spectrometry (LCMS/MS) for protein identification.

Fig. 1 shows the 1D gels for the protein corona formed around the three different NPs (AuNPs-protein corona, AgNPs-protein corona, MNPs-protein corona) visible after Coomassie staining. As may be seen, it is quickly noted that there is a difference in the intensity of the bands on the gel profiles for the healthy controls (from $\mathrm{C} 1$ to $\mathrm{C} 8$ ) and the patients (from P1 to P8) for each type of nanoparticle. However, no conclusion can be drawn unless the proteins are identified. 
M. del Pilar Chantada-Vázquez, A. C. López, M. G. Vence, S. Vázquez-Estévez, B. Acea-Nebril, D. G. Calatayud, T. Jardiel, S. B. Bravo and C. Núñez, J. Proteomics, 2020, 212, 103581. DOI:

10.1016/j.jprot.2019.103581

AuNPs protein corona
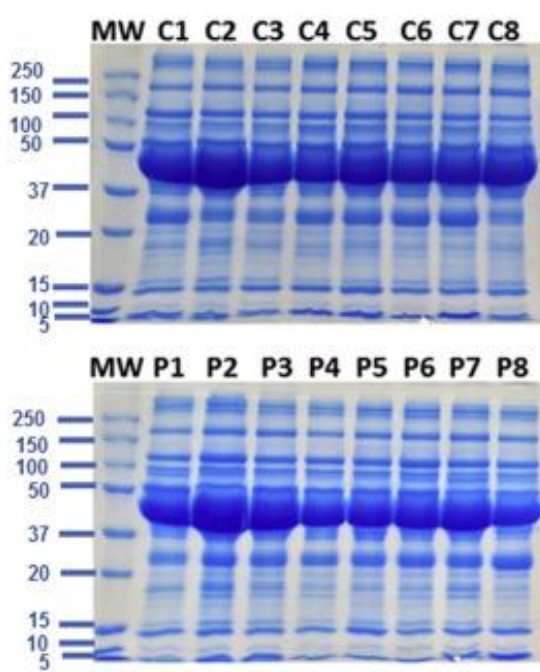

AgNPs protein corona
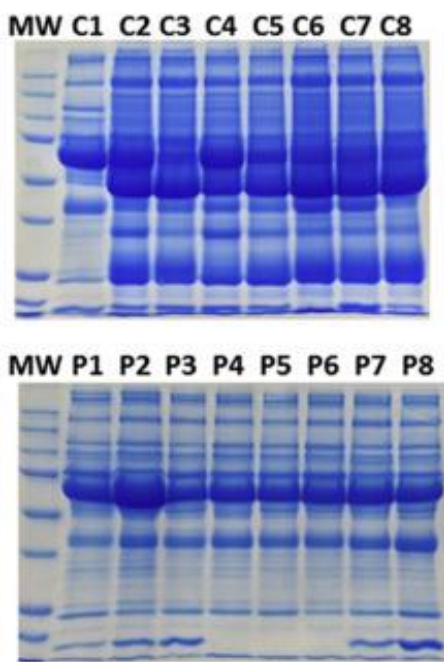

MNPs protein corona
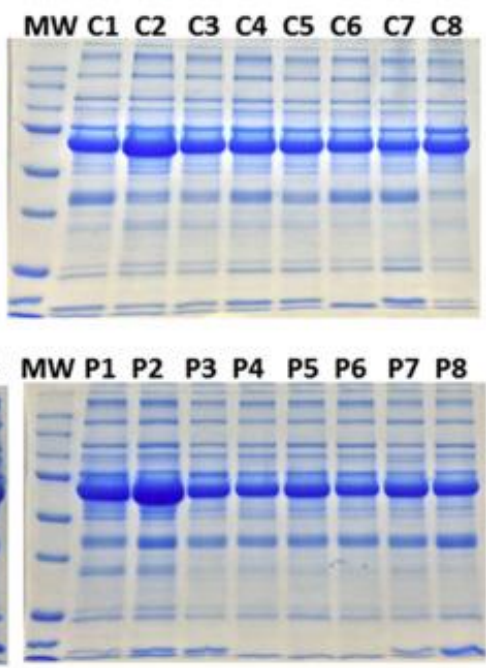

Fig. 1. 1D-SDS-PAGE of protein coronas formed around $10.02 \pm 0.91 \mathrm{~nm}$ gold nanoparticles (AuNPs), $9.73 \pm 1.70 \mathrm{~nm}$ silver nanoparticles (AgNPs) and $9.30 \pm 0.67 \mathrm{~nm}$ magnetic nanoparticles (MNPs) after their incubation with serum aliquots $(x 2)$ belonging to the eight disease-free individuals $(\mathrm{C} 1-\mathrm{C} 8)$ and eight triple negative breast cancer patients (P1-P8). On the left, it marks the lane with Mw protein standards.

As Fig. 2 shows, 192, 161 and 142 proteins were commonly detected in the protein corona formed around AuNPs, AgNPs, and MNPs, after their incubation with serum samples of the eight triple negative breast cancer patients and eight healthy controls, respectively.

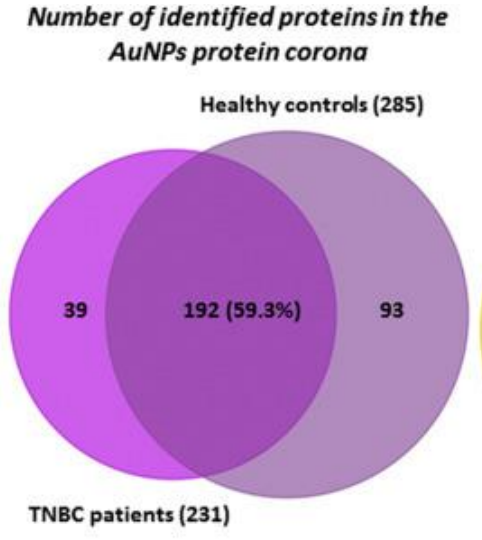

TNBC patients (231)
Number of identified proteins in the AgNPs protein corona

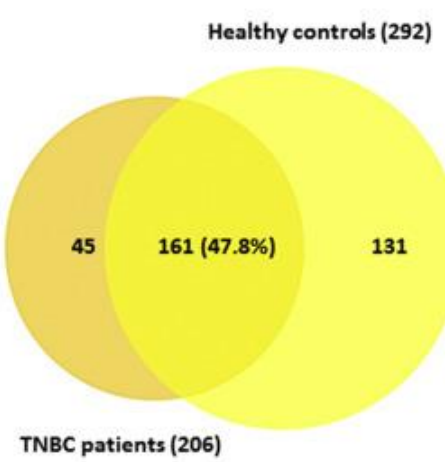

Number of identified proteins in the MNPs protein corona

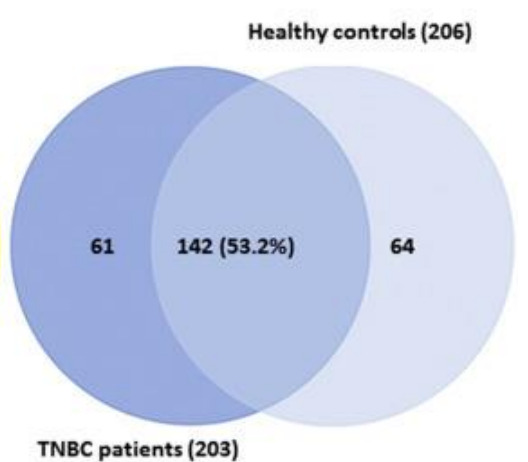

Fig. 2. Quantitative Venn diagrams showing the number of identified proteins found in the protein corona of $10.02 \pm 0.91 \mathrm{~nm}$ gold nanoparticles (AuNPs), $9.73 \pm 1.70 \mathrm{~nm}$ silver nanoparticles (AgNPs) and $9.30 \pm 0.67 \mathrm{~nm}$ magnetic nanoparticles (MNPs) after their incubation with serum from eight triple negative breast cancer patients and eight healthy controls.

In the particular case of all serum samples from healthy controls, 285, 292 and 206 were identified on the surface of AuNPs $(10.02 \pm 0.91 \mathrm{~nm}), \operatorname{AgNPs}(9.73 \pm 1.70 \mathrm{~nm})$ and MNPs $(9.30 \pm 0.67 \mathrm{~nm})$, respectively. From them, 149 proteins were commonly detected in the protein corona of all three different types of NPs. However, 202 different proteins were found on the three distinct NPs surface: 71 different proteins on the AuNPs, 85 on the AgNPs, and 46 individual proteins on the MNPs (see Table S1). 
M. del Pilar Chantada-Vázquez, A. C. López, M. G. Vence, S. Vázquez-Estévez, B. Acea-Nebril, D. G. Calatayud, T. Jardiel, S. B. Bravo and C. Núñez, J. Proteomics, 2020, 212, 103581. DOI:

10.1016/j.jprot.2019.103581

Furthermore, 231, 206 and 203 were found in the surface of AuNPs $(10.02 \pm 0.91 \mathrm{~nm})$, AgNPs $(9.73 \pm 1.70 \mathrm{~nm})$ and MNPs $(9.30 \pm 0.67 \mathrm{~nm})$ after their incubation with all serum aliquots $(x 2)$ from eight triple negative breast cancer patients (6 protein samples per individual: 2 incubated with AuNPs, 2 with AgNPs and 2 with MNPs) (see Table S2). A total of 138 proteins were commonly found in the protein corona of all three different types of NPs. However, 142 different proteins were found in the three different NPs surface: 56 different proteins on the AuNPs, 33 on the AgNPs and 53 individual proteins on the MNPs.

Fractionation of the proteome using AuNPs, AgNPs, and MNPs allows for the identification of 39 (see Table 2), 45 (see Table 3) and 61 (see Table 4) protein biomarkers in the pellet of all patient samples, respectively (see Fig. 3). Remarkably, these proteins were not identified in the healthy control. These potential biomarkers came from different cellular components; most of them from the nucleus and cytoplasm (see Fig. 4). Protein biomarkers also showed different functionality and are constituted by proteins implicated in the immune response, followed by proteins with an enzymatic function, structural, transporter, inflammatory, signal transduction, and with antibiotic/antibacterial properties.

Table 2. Selection of identified single-detected corona proteins bound to the $10.02 \pm 0.91 \mathrm{~nm}$ AuNPs after $30 \mathrm{~min}$ incubation and subsequent washing.

\begin{tabular}{|c|c|c|c|c|c|}
\hline Protein name & UniProt name & $\begin{array}{l}\text { Entry } \\
\text { name }\end{array}$ & Gene & $\begin{array}{l}\text { Mass } \\
\text { (kDa) }\end{array}$ & Function \\
\hline Actin, cytoplasmic 2 & ACTG_HUMAN & P63261 & ACTG1 & 41.7 & Cell mobility \\
\hline Atypical & & & & & Involved \\
\hline $\begin{array}{l}\mathrm{COQ} 8 \mathrm{~B}, \\
\text { mitochondrial }\end{array}$ & COQ8B_HUMAN & Q96D53 & COQ8B & 60.1 & $\begin{array}{l}\text { biosynthesis of coenzyme } \\
Q\end{array}$ \\
\hline $\begin{array}{l}\text { Beta- } \\
\text { ureidopropionase }\end{array}$ & BUP1_HUMAN & Q9UBR1 & UPB1 & 43.1 & Catalytic activity \\
\hline $\begin{array}{l}\text { Brefeldin A-inhibited } \\
\text { guanine nucleotide- } \\
\text { exchange protein } 3\end{array}$ & BIG3_HUMAN & Q5TH69 & ARFGEF3 & 240.6 & $\begin{array}{l}\text { Participates in the } \\
\text { regulation of systemic } \\
\text { glucose homeostasis }\end{array}$ \\
\hline $\begin{array}{l}85 / 88 \mathrm{kDa} \text { calcium- } \\
\text { independent } \\
\text { phospholipase A2 }\end{array}$ & PLPL9_HUMAN & 060733 & PLA2G6 & 89.9 & Catalytic activity \\
\hline $\begin{array}{l}\text { Cilia- and flagella- } \\
\text { associated protein } \\
100\end{array}$ & CP100_HUMAN & Q494V2 & CFAP100 & 71.1 & $\begin{array}{l}\text { Plays a role in } \\
\text { ciliary/flagellar motility by } \\
\text { regulating the assembly } \\
\text { and the activity of } \\
\text { axonemal inner dynein } \\
\text { arm }\end{array}$ \\
\hline
\end{tabular}


M. del Pilar Chantada-Vázquez, A. C. López, M. G. Vence, S. Vázquez-Estévez, B. Acea-Nebril, D. G. Calatayud, T. Jardiel, S. B. Bravo and C. Núñez, J. Proteomics, 2020, 212, 103581. DOI:

10.1016/j.jprot.2019.103581

\begin{tabular}{|c|c|c|c|c|c|}
\hline Protein name & UniProt name & $\begin{array}{l}\text { Entry } \\
\text { name }\end{array}$ & Gene & $\begin{array}{l}\text { Mass } \\
(\mathrm{kDa})\end{array}$ & Function \\
\hline Coagulation factor XI & FA11_HUMAN & P03951 & F11 & 70.1 & Catalytic activity \\
\hline $\begin{array}{l}\text { Contactin-associated } \\
\text { protein-like } 2\end{array}$ & CNTP2_HUMAN & Q9UHC6 & CNTNAP2 & 148.2 & $\begin{array}{l}\text { Plays a role in the } \\
\text { formation of functional } \\
\text { distinct domains critical } \\
\text { for saltatory conduction } \\
\text { of nerve impulses in } \\
\text { myelinated nerve fibers }\end{array}$ \\
\hline DNA topoisomerase 1 & TOP1_HUMAN & P11387 & TOP1 & 90.7 & Catalyctic activity \\
\hline $\begin{array}{l}\text { Dynein assembly } \\
\text { factor } 1 \text {, axonemal }\end{array}$ & DAAF1_HUMAN & Q8NEP3 & DNAAF1 & 80.0 & $\begin{array}{l}\text { Plays a role in cytoplasmic } \\
\text { preassembly of dynein } \\
\text { arms }\end{array}$ \\
\hline $\begin{array}{l}\text { E3 ubiquitin-protein } \\
\text { ligase SHPRH }\end{array}$ & SHPRH_HUMAN & Q149N8 & SHPRH & 193.1 & $\begin{array}{l}\text { Enzyme involved in DNA } \\
\text { repair }\end{array}$ \\
\hline $\begin{array}{l}\text { Estrogen } \\
\text { sulfotransferase }\end{array}$ & ST1E1_HUMAN & P49888 & SULT1E1 & 35.1 & $\begin{array}{l}\text { Catalytic activity. May } \\
\text { play a role in the } \\
\text { regulation of estrogen } \\
\text { receptor activity by } \\
\text { metabolizing free } \\
\text { estradiol }\end{array}$ \\
\hline
\end{tabular}

[F-actin]-

monooxygenase MICA3_HUMAN Q7RTP6 MICAL3 224.3 Catalytic activity

MICAL3

Glial fibrillary acidic GFAP_HUMAN P14136 GFAP
protein

Cell-specific marker

49.9

during the development

of the central nervous

system

Catalytic activity. Acts as a coactivator for estrogen

Histone-lysine $\mathrm{N}-$
methyltransferase 2D

593.4 receptor by being recruited by ESR1, thereby activating transcription

Immunoglobulin

lambda variable 3-27

LV327_HUMAN P01718 IGLV3-27 12.2 Immune response 
M. del Pilar Chantada-Vázquez, A. C. López, M. G. Vence, S. Vázquez-Estévez, B. Acea-Nebril, D. G. Calatayud, T. Jardiel, S. B. Bravo and C. Núñez, J. Proteomics, 2020, 212, 103581. DOI:

10.1016/j.jprot.2019.103581

\begin{tabular}{|c|c|c|c|c|c|}
\hline Protein name & UniProt name & $\begin{array}{l}\text { Entry } \\
\text { name }\end{array}$ & Gene & $\begin{array}{l}\text { Mass } \\
(\mathrm{kDa})\end{array}$ & Function \\
\hline $\begin{array}{l}\text { Inositol } \\
\text { hexakisphosphate } \\
\text { kinase } 2\end{array}$ & IP6K2_HUMAN & Q9UHH9 & IP6K2 & 49.2 & Catalytic activity \\
\hline $\begin{array}{l}\text { Inositol } 1,4,5- \\
\text { trisphosphate } \\
\text { receptor type } 3\end{array}$ & ITPR3_HUMAN & Q14573 & ITPR3 & 304.1 & $\begin{array}{l}\text { Receptor for inositol } \\
1,4,5 \text {-trisphosphate }\end{array}$ \\
\hline $\begin{array}{l}\text { Intraflagellar } \\
\text { transport protein } 74 \\
\text { homolog }\end{array}$ & IFT74_HUMAN & Q96LB3 & IFT74 & 69.2 & Transporter activity \\
\hline $\begin{array}{l}\text { Janus kinase and } \\
\text { microtubule- } \\
\text { interacting protein } 1\end{array}$ & JKIP1_HUMAN & Q96N16 & JAKMIP1 & 73.2 & $\begin{array}{l}\text { Plays a role in the } \\
\text { microtubule-dependent } \\
\text { transport of the GABA-B } \\
\text { receptor }\end{array}$ \\
\hline Lebercilin & LCA5_HUMAN & Q86VQ0 & LCA5 & 80.5 & Transporter activity \\
\hline $\begin{array}{l}\text { MaFF-interacting } \\
\text { protein }\end{array}$ & MAFIP_HUMAN & Q8WZ33 & MAFIP & 13.9 & $\begin{array}{l}\text { Inhibits cell growth and } \\
\text { colony-forming efficiency }\end{array}$ \\
\hline $\begin{array}{l}\text { Matrix } \\
\text { metalloproteinase- } 9\end{array}$ & MMP9_HUMAN & P14780 & MMP9 & 78.5 & Catalytic activity \\
\hline $\begin{array}{l}\text { Microtubule- } \\
\text { associated protein } 2\end{array}$ & MTAP2_HUMAN & P11137 & MAP2 & 199.5 & $\begin{array}{l}\text { Stabilizes the } \\
\text { microtubules against } \\
\text { depolymerization }\end{array}$ \\
\hline Mucolipin-3 & MCLN3_HUMAN & Q8TDD5 & MCOLN3 & 64.2 & $\begin{array}{l}\text { Pays a role in the } \\
\text { regulation of membrane } \\
\text { trafficking events }\end{array}$ \\
\hline $\begin{array}{l}\text { Multidrug resistance } \\
\text { protein } 1\end{array}$ & MDR1_HUMAN & P08183 & ABCB1 & 141.5 & $\begin{array}{l}\text { Responsible for } \\
\text { decreased drug } \\
\text { accumulation in } \\
\text { multidrug-resistant cells }\end{array}$ \\
\hline Nebulette & NEBL_HUMAN & 076041 & NEBL & 116.4 & $\begin{array}{l}\text { Plays an important role in } \\
\text { the assembly of the Z-disk }\end{array}$ \\
\hline $\begin{array}{l}\text { Nucleoporin NUP188 } \\
\text { homolog }\end{array}$ & NU188_HUMAN & Q5SRE5 & NUP188 & 196.1 & $\begin{array}{l}\text { May function as a } \\
\text { component of the nuclear } \\
\text { pore complex (NPC) }\end{array}$ \\
\hline
\end{tabular}


M. del Pilar Chantada-Vázquez, A. C. López, M. G. Vence, S. Vázquez-Estévez, B. Acea-Nebril, D. G. Calatayud, T. Jardiel, S. B. Bravo and C. Núñez, J. Proteomics, 2020, 212, 103581. DOI:

10.1016/j.jprot.2019.103581

\begin{tabular}{|c|c|c|c|c|c|}
\hline Protein name & UniProt name & $\begin{array}{l}\text { Entry } \\
\text { name }\end{array}$ & Gene & $\begin{array}{l}\text { Mass } \\
\text { (kDa) }\end{array}$ & Function \\
\hline $\begin{array}{l}\mathrm{PC} \text { membrane } \\
\text { recruitment protein } 2\end{array}$ & AMER2_HUMAN & Q8N7J2 & AMER2 & 69.5 & $\begin{array}{l}\text { Negative regulator of the } \\
\text { canonical Wnt signaling } \\
\text { pathway involved in } \\
\text { neuroectodermal } \\
\text { patterning }\end{array}$ \\
\hline Protein ELYS & ELYS_HUMAN & Q8WYP5 & AHCTF1 & 252.5 & $\begin{array}{l}\text { Required for the assembly } \\
\text { of a functional nuclear } \\
\text { pore complex (NPC) on } \\
\text { the surface of } \\
\text { chromosomes }\end{array}$ \\
\hline $\begin{array}{l}\text { Protein phosphatase } \\
1 \text { regulatory subunit } \\
26\end{array}$ & PPR26_HUMAN & Q5T8A7 & PPP1R26 & 127.3 & $\begin{array}{l}\text { Inhibits phosphatase } \\
\text { activity of protein } \\
\text { phosphatase } 1 \text { (PP1) } \\
\text { complexes. May positively } \\
\text { regulate cell proliferation. }\end{array}$ \\
\hline Protein ZGRF1 & ZGRF1_HUMAN & Q86YA3 & ZGRF1 & 236.6 & $\begin{array}{l}\text { Zinc ion binding that } \\
\text { inhibits factors Xa and Xla } \\
\text { of the coagulation } \\
\text { cascade }\end{array}$ \\
\hline
\end{tabular}

Putative

transmembrane

protein encoded by

CL067_HUMAN Q96M19 LINC00477 18.2

Product of a dubious CDS

LINC00477

prediction. May be a non-

coding RNA

Serine protease 33

PRS33_HUMAN PRSS33 PRSS33

29.8 Catalytic activity

Serine-protein kinase

ATM

ATM_HUMAN Q13315 ATM

Activates checkpoint

signaling upon double

350.7 strand breaks (DSBs),

apoptosis and genotoxic

stresses

$\begin{aligned} & \text { Serum amyloid A-1 SAA1_HUMAN P0DJI8 SAA1 } \\ & \text { protein }\end{aligned}$
13.5 Inflammatory response

Sodium-dependent

noradrenaline

SC6A2_HUMAN P23975 SLC6A2 69.3 Transporter activity

transporter 
M. del Pilar Chantada-Vázquez, A. C. López, M. G. Vence, S. Vázquez-Estévez, B. Acea-Nebril, D.

G. Calatayud, T. Jardiel, S. B. Bravo and C. Núñez, J. Proteomics, 2020, 212, 103581. DOI:

10.1016/j.jprot.2019.103581

Protein name UniProt name $\begin{aligned} & \text { Entry } \\ & \text { name }\end{aligned}$ Gene $\quad \begin{aligned} & \text { Mass } \\ & (\mathrm{kDa})\end{aligned}$

$\begin{array}{lllll}\begin{array}{l}\text { Suppressor } \\ \text { tumorigenicity } \\ \text { protein }\end{array} & \text { of } & \text { ST7_HUMAN } & \text { Q9NRC1 ST7 } & 67.2 \begin{array}{l}\text { Acts as a tumor } \\ \text { suppressor }\end{array} \\ \text { Vasorin } & \text { VASN_HUMAN } & \text { Q6EMK4 VASN } & 71.7 \begin{array}{l}\text { May act as an inhibitor of } \\ \text { TGF-beta signaling }\end{array}\end{array}$

The accession number, gene name, species (Human), molecular weight (kDa) and protein function were reported.

Table 3. Selection of identified single-detected corona proteins bound to the $9.73 \pm 1.70 \mathrm{~nm}$ AgNPs after 30 min incubation and subsequent washing.

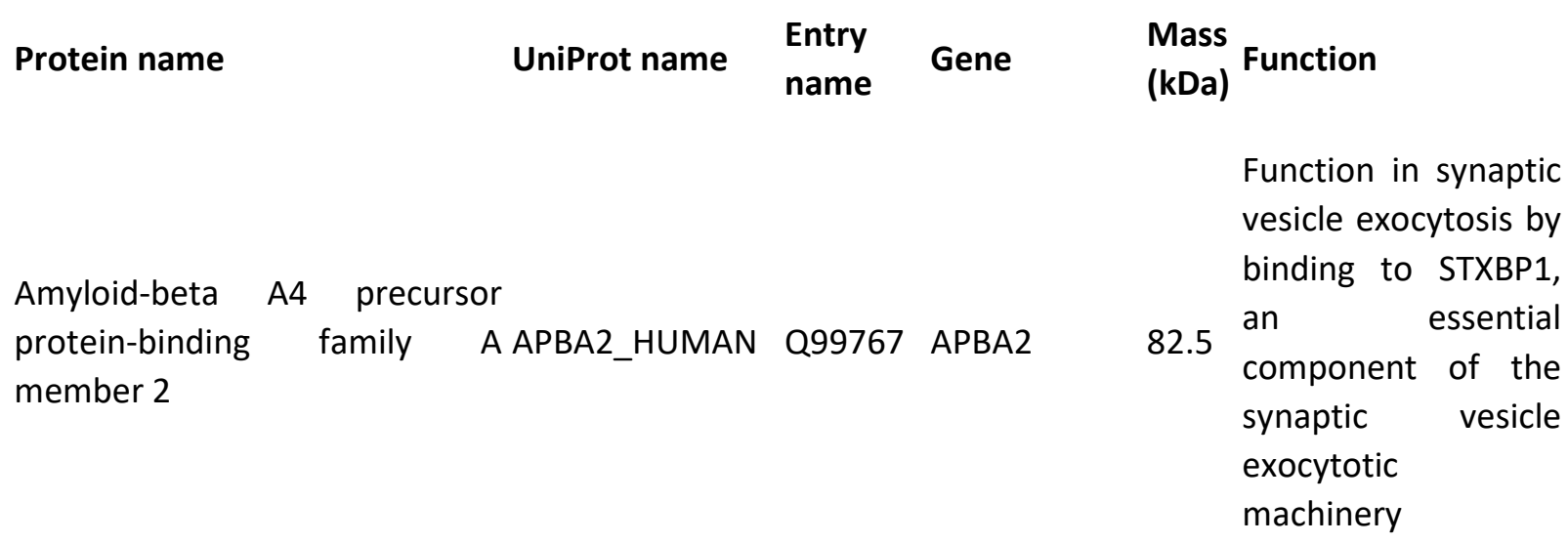

Ankyrin repeat domain-
containing protein 20B

Ankyrin repeat and sterile alpha

motif domain-containing ANS1B_HUMAN Q7Z6G8 ANKS1B

protein 1B

Plays a role as a

Bone morphogenetic protein 10 BMP10_HUMAN 095393 BMP10

138.1 modulator of APP

processing

Inhibits endothelial

cell migration and

growth. May reduce

48.0 cell migration and

cell matrix adhesion

in breast cancer cell lines.

Essential component

Bromodomain adjacent to zinc

finger domain protein $2 \mathrm{~A}$

BAZ2A_HUMAN Q9UIF9 BAZ2A

211.2 of the NoRC
remodeling
complex) complex 
M. del Pilar Chantada-Vázquez, A. C. López, M. G. Vence, S. Vázquez-Estévez, B. Acea-Nebril, D.

G. Calatayud, T. Jardiel, S. B. Bravo and C. Núñez, J. Proteomics, 2020, 212, 103581. DOI:

10.1016/j.jprot.2019.103581

Protein name UniProt name $\begin{aligned} & \text { Entry } \\ & \text { name }\end{aligned}$ Gene
Caspase recruitment domain- CAR11_HUMAN Q9BXL7 CARD11
containing protein 11

Complement factor $\mathrm{H}$-related protein 3

FHR3_HUMAN Q02985 CFHR3

Complement factor H-related protein 4

FHR4_HUMAN Q92496 CFHR4

Cyclin-dependent kinase 2 CDK2_HUMAN P24941 CDK2

Dual specificity protein phosphatase 9

DUS9_HUMAN Q99956 DUSP9

Dystonin DYST_HUMAN Q03001 DST

EGF-containing fibulin-like

extracellular matrix protein 1

FBLN3_HUMAN Q12805 EFEMP1

GREB1-like protein

GRB1L_HUMAN Q9C091 GREB1L

\section{Mass \\ (kDa) \\ Function}

that mediates

silencing of a fraction of rDNA

Involved in the costimulatory signal essential for T-cell

133.3 receptor (TCR)mediated T-cell activation. Also activates the TORC1 signaling pathway

Involved in

37.3 complement regulation

65.3 Plays a role in lipid metabolism

33.9 Catalytic activity

41.9 Inactivates MAP kinases

Acts as an integrator of intermediate 860.6 filaments, actin and microtubule cytoskeleton networks

Binds EGFR, the EGF receptor, inducing EGFR autophosphorylation 54.6 and the activation of downstream signaling pathways. May play a role in cell adhesion and migration

214.3 Plays a major role in early metanephros 
M. del Pilar Chantada-Vázquez, A. C. López, M. G. Vence, S. Vázquez-Estévez, B. Acea-Nebril, D.

G. Calatayud, T. Jardiel, S. B. Bravo and C. Núñez, J. Proteomics, 2020, 212, 103581. DOI:

10.1016/j.jprot.2019.103581

Protein name

Hemoglobin subunit gamma-2 HBG2_HUMAN P69892 HBG2

Histone-lysine

methyltransferase $2 \mathrm{~A}$

$\mathrm{N}-$

KMT2A_HUMAN Q03164 KMT2A

HV323_HUMAN P01764 IGHV3-23

3-23

Importin-4

IPO4_HUMAN Q8TEX9 IPO4

Keratin, type I cytoskeletal $9 \quad$ K1C9_HUMAN P35527 KRT9

LINE-1 type transposase

domain-containing protein 1

LITD1_HUMAN Q5T7N2 L1TD1

Lysosomal-trafficking regulator LYST_HUMAN Q99698 LYST

Matrix metalloproteinase-9 MMP9_HUMAN P14780 MMP9

Microtubule-associated protein $1 \mathrm{~A}$

MAP1A_HUMAN P78559 MAP1A A

MORC family CW-type zinc finger protein 1
MORC1_HUMAN Q86VD1 MORC1 $\underset{(k D a)}{\text { Mass }}$ Function

and genital

development

Gamma chains make

up the fetal

16.1 hemoglobin $F$, in

combination with

alpha chains

431.8 Catalytic activity

12.6 Immune response

Functions in nuclear

118.7 protein import as

nuclear transport

receptor

62.1 Structural

98.8 Single-stranded RNA binding

Required for sorting endosomal resident

429,1 proteins into late multivesicular

endosomes

78.5 Catalytic activity

Structural protein involved in the filamentous cross-

305.5 bridging between microtubules and other skeletal elements

112.9 Zinc ion binding. 
M. del Pilar Chantada-Vázquez, A. C. López, M. G. Vence, S. Vázquez-Estévez, B. Acea-Nebril, D.

G. Calatayud, T. Jardiel, S. B. Bravo and C. Núñez, J. Proteomics, 2020, 212, 103581. DOI:

10.1016/j.jprot.2019.103581

Protein name

Nuclear distribution protein nudE-like 1

NDEL1_HUMAN Q9GZM8 NDEL1

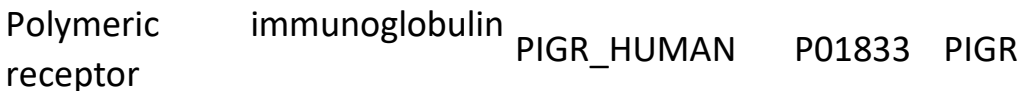

Polypeptide

$\mathrm{N}-$

acetylgalactosaminyltransferase GLT13_HUMAN Q8IUC8 GALNT13 13

Probable guanine nucleotide exchange factor MCF2L2

MF2L2_HUMAN Q86YR7 MCF2L2

Pro-epidermal growth factor EGF_HUMAN P01133 EGF

Properdin

PROP_HUMAN P27918 CFP

Protein MMS22-like

MMS22_HUMAN Q6ZRQ5 MMS22L

Protein phosphatase homolog

PTC7

PPTC7_HUMAN Q8NI37 PPTC7

Protein Shroom3
(kDa) Function

Required for organization of the cellular microtubule

38.4 array and

microtubule

anchoring at the centrosome

This receptor binds polymeric $\operatorname{lgA}$ and

83.3 IgM at the basolateral surface of epithelial cells

64.0 Catalytic activity

Functions as a 126.9 guanine nucleotide exchange factor

Stimulates the growth of various 133.9 epidermal and epithelial tissues in vivo and in vitro

A positive regulator

51.3 of the alternate
pathway complement

Maintain genome 142.3 integrity during DNA replication

32.6 Catalytic activity

Controls cell shape changes in the 216.8 neuroepithelium during neural tube closure 
M. del Pilar Chantada-Vázquez, A. C. López, M. G. Vence, S. Vázquez-Estévez, B. Acea-Nebril, D.

G. Calatayud, T. Jardiel, S. B. Bravo and C. Núñez, J. Proteomics, 2020, 212, 103581. DOI:

10.1016/j.jprot.2019.103581

\begin{tabular}{|c|c|c|c|}
\hline Protein name & UniProt name & $\begin{array}{l}\text { Entry } \\
\text { name }\end{array}$ & Gene \\
\hline Protein ZGRF1 & ZGRF1_HUMAN & Q86YA3 & ZGRF1 \\
\hline $\begin{array}{l}\text { Putative solute carrie } \\
\text { anion transporter } \\
\text { member } 1 \mathrm{~B} 7\end{array}$ & SO1B7_HUMAN & G3V0H7 & SLCO1B7 \\
\hline
\end{tabular}

Ras-interacting protein 1

RAIN_HUMAN Q5U651 RASIP1

Ribosomal protein S6 kinase alpha-1

KS6A1_HUMAN Q15418 RPS6KA1

Short coiled-coil protein

SCOC_HUMAN Q9UIL1 SCOC

Structural maintenance of chromosomes protein 6

of SMC6_HUMAN Q96SB8 SMC6 chromosomes protein 6

Synaptotagmin-5

SYT5_HUMAN O00445 SYT5

Tudor protein 1

domain-containing

TDRD1_HUMAN Q9BXT4 TDRD1

Tyrosine--tRNA

cytoplasmic ligase, SYYC_HUMAN P54577 YARS

\section{Mass \\ (kDa) \\ Function}

Zinc ion binding that

236.6 inhibits factors Xa
and Xla of the coagulation cascade

May encode a non-

71.2 functional truncated protein

Acts as a critical and vascular-specific 103.4 $\begin{aligned} & \text { regulator of GTPase } \\ & \text { signaling, cell }\end{aligned}$ architecture, and adhesion

82.7 Catalytic activity

Positive regulator of 18.0 amino acid starvation-induced autophagy

126.3 Structural

May be involved in

42.9 Ca2+-dependent exocytosis of secretory vesicles

Acts via the piRNA metabolic process, which mediates the 132.0 repression of transposable elements during meiosis

59.1 Catalytic activity 
M. del Pilar Chantada-Vázquez, A. C. López, M. G. Vence, S. Vázquez-Estévez, B. Acea-Nebril, D.

G. Calatayud, T. Jardiel, S. B. Bravo and C. Núñez, J. Proteomics, 2020, 212, 103581. DOI:

10.1016/j.jprot.2019.103581

\begin{tabular}{|c|c|c|c|c|c|}
\hline Protein name & UniProt name & $\begin{array}{l}\text { Entry } \\
\text { name }\end{array}$ & Gene & $\begin{array}{l}\text { Mass } \\
\text { (kDa) }\end{array}$ & Function \\
\hline Vigilin & VIGLN_HUMAN & Q00341 & HDLBP & 141.4 & $\begin{array}{l}\text { Protect cells from } \\
\text { over-accumulation } \\
\text { of cholesterol }\end{array}$ \\
\hline von Willebrand factor & VWF_HUMAN & P04275 & VWF & 220 & $\begin{array}{l}\text { Plays a major role in } \\
\text { blood coagulation }\end{array}$ \\
\hline Wee1-like protein kinase & WEE1_HUMAN & P30291 & WEE1 & 71.6 & $\begin{array}{l}\text { Acts as a negative } \\
\text { regulator of entry } \\
\text { into mitosis }\end{array}$ \\
\hline Zinc finger protein 114 & ZN114_HUMAN & Q8NC26 & ZNF114 & 47.7 & $\begin{array}{l}\text { May be involved in } \\
\text { transcriptional } \\
\text { regulation. }\end{array}$ \\
\hline
\end{tabular}

The accession number, gene name, species (Human), molecular weight (kDa) and protein function were reported.

Table 4. Selection of identified single-detected corona proteins bound to the $9.30 \pm 0.67 \mathrm{~nm}$ MNPs after 30 min incubation and subsequent washing.

\begin{tabular}{|c|c|c|c|c|c|}
\hline Protein name & UniProt name & Entry name & Gene & $\begin{array}{l}\text { Mass } \\
\text { (kDa) }\end{array}$ & Function \\
\hline $\begin{array}{l}\text { ATP-binding cassette sub- } \\
\text { family B member } 5\end{array}$ & $\begin{array}{l}\text { ABCB5_HUMA } \\
\mathrm{N}\end{array}$ & Q2M3G0 & ABCB5 & 138.6 & $\begin{array}{l}\text { Transporter } \\
\text { activity }\end{array}$ \\
\hline Bile salt-activated lipase & CEL_HUMAN & P19835 & CEL & 79.3 & Catalytic activity \\
\hline $\begin{array}{l}\text { Cathelicidin antimicrobial } \\
\text { peptide }\end{array}$ & $\begin{array}{l}\text { CAMP_HUMA } \\
\mathrm{N}\end{array}$ & P49913 & CAMP & 19.3 & $\begin{array}{l}\text { Antibacterial } \\
\text { activity }\end{array}$ \\
\hline Ceramide synthase 4 & $\begin{array}{l}\text { CERS4_HUMA } \\
\mathrm{N}\end{array}$ & Q9HA82 & CERS4 & 46.4 & $\begin{array}{l}\text { May be either a } \\
\text { bona fide } \\
\text { (dihydro)cerami } \\
\text { de synthase or a } \\
\text { modulator of its } \\
\text { activity }\end{array}$ \\
\hline C-reactive protein & CRP_HUMAN & P02741 & CRP & 25.0 & $\begin{array}{l}\text { Displays several } \\
\text { functions } \\
\text { associated with } \\
\text { host defense }\end{array}$ \\
\hline
\end{tabular}


M. del Pilar Chantada-Vázquez, A. C. López, M. G. Vence, S. Vázquez-Estévez, B. Acea-Nebril, D. G. Calatayud, T. Jardiel, S. B. Bravo and C. Núñez, J. Proteomics, 2020, 212, 103581. DOI:

10.1016/j.jprot.2019.103581

Protein name

C-type lectin domain family 4 member $\mathrm{F}$

CLC4F_HUMAN Q8N1N0

Cystatin-F

CYTF_HUMAN 076096

DDB1- and CUL4-associated DCA15_HUMA factor 15

$\mathrm{N}$

Q66K64

DCAF15

$(20)$

DNA topoisomerase 2-TOPB1_HUMA

binding protein 1

$\mathrm{N}$

Q92547

TOPBP1

Dynein heavy chain 10, DYH10_HUMA Q8IVF4
axonemal
Ellis-van Creveld syndrome EVC_HUMAN P57679
protein

CLEC4F

CST7
66.5

\section{Mass \\ (kDa) \\ Function}

Receptor with an

affinity for

65.5 galactose and fucose. Could be involved in

endocytosis

May play a role in immune regulation through

16.4 inhibition of a unique target in the hematopoietic system

May be involved in ubiquitination and degradation through a DBB1CUL4 E3 proteinubiquitin ligase

Binds doublestranded DNA breaks and nicks as well as singlestranded DNA

DNAH10 514.8

Presents ATPase activity

Involved in endochondral

EVC $\quad 111.9$ growth and skeletal development

DNA repair protein required for FANCD2 ubiquitination 
M. del Pilar Chantada-Vázquez, A. C. López, M. G. Vence, S. Vázquez-Estévez, B. Acea-Nebril, D.

G. Calatayud, T. Jardiel, S. B. Bravo and C. Núñez, J. Proteomics, 2020, 212, 103581. DOI:

10.1016/j.jprot.2019.103581

Protein name

F-box only protein 42
UniProt name Entry name Gene

$\begin{array}{llll}\text { FBX42_HUMA } & & & \\ \mathrm{N} & \text { Q6P3S6 } & \text { FBXO42 } & 77.8\end{array}$

LG3BP_HUMA Q08380

LGALS3BP 65.3

Specifically

recognizes

p53/TP53,

promoting its

ubiquitination

and degradation

Stimulate host

defense against

viruses and

tumor cells

\begin{tabular}{|c|c|c|c|c|c|}
\hline $\begin{array}{ll}\text { HEAT } & \text { repeat-containing } \\
\text { protein } 4 & \end{array}$ & $\begin{array}{l}\text { g HEAT4_HUMA } \\
\mathrm{N}\end{array}$ & Q86WZ0 & HEATR4 & 117.2 & - \\
\hline $\begin{array}{l}\text { Immunoglobulin } \\
\text { variable 6-1 }\end{array}$ & $\begin{array}{l}\text { y HV601_HUMA } \\
\mathrm{N}\end{array}$ & $\begin{array}{l}\text { AOAOB } 4 J 1 U \\
7\end{array}$ & IGHV6-1 & 13.5 & $\begin{array}{l}\text { Imuune } \\
\text { response }\end{array}$ \\
\hline $\begin{array}{l}\text { Immunoglobulin } \\
\text { variable } 2-24\end{array}$ & $\begin{array}{l}\text { KV224_HUMA } \\
\mathrm{N}\end{array}$ & $\begin{array}{l}\text { A0AOC } 4 \text { DH6 } \\
8\end{array}$ & IGKV2-24 & 13.1 & $\begin{array}{l}\text { Immune } \\
\text { response }\end{array}$ \\
\hline $\begin{array}{l}\text { Immunoglobulin } \\
\text { variable 3-27 }\end{array}$ & $\begin{array}{l}\text { LV327_HUMA } \\
\mathrm{N}\end{array}$ & P01718 & IGLV3-27 & 12.2 & $\begin{array}{l}\text { Immune } \\
\text { response }\end{array}$ \\
\hline Kallistatin & KAIN_HUMAN & P29622 & SERPINA4 & 48.5 & $\begin{array}{l}\text { Enzyme } \\
\text { regulator } \\
\text { inhibitor }\end{array}$ \\
\hline Keratin, type I cytoskeletal 14 & $\begin{array}{l}\text { K1C14_HUMA } \\
\mathrm{N}\end{array}$ & P02533 & KRT14 & 51.6 & Structural \\
\hline Keratin, type II cuticular Hb1 & $\begin{array}{l}\text { KRT81_HUMA } \\
\mathrm{N}\end{array}$ & Q14533 & KRT81 & 54.9 & Structural \\
\hline Lebercilin & LCA5_HUMAN & Q86VQ0 & LCA5 & 80.5 & $\begin{array}{l}\text { Transporter } \\
\text { activity }\end{array}$ \\
\hline $\begin{array}{l}\text { LINE-1 type transposase } \\
\text { domain-containing protein } 1\end{array}$ & LITD1_HUMAN & Q5T7N2 & L1TD1 & 98.8 & $\begin{array}{l}\text { Single-stranded } \\
\text { RNA binding }\end{array}$ \\
\hline $\begin{array}{l}\text { Lipopolysaccharide-binding } \\
\text { protein }\end{array}$ & LBP_HUMAN & P18428 & LBP & 53.4 & $\begin{array}{l}\text { Immune } \\
\text { response }\end{array}$ \\
\hline LRP chaperone MESD & MESD_HUMAN & Q14696 & MESD & 26.1 & $\begin{array}{l}\text { Assisting the } \\
\text { folding of beta- } \\
\text { propeller/EGF }\end{array}$ \\
\hline
\end{tabular}


M. del Pilar Chantada-Vázquez, A. C. López, M. G. Vence, S. Vázquez-Estévez, B. Acea-Nebril, D. G. Calatayud, T. Jardiel, S. B. Bravo and C. Núñez, J. Proteomics, 2020, 212, 103581. DOI:

10.1016/j.jprot.2019.103581

Protein name

UniProt name Entry name Gene
Mass
(kDa) Function

modules within the family of low-density lipoprotein receptors

(LDLRs)
MANSC domain-containing MANS1_HUMA protein 1

$\mathrm{N}$

Meckelin MKS3_HUMAN Q5HYA8

Mitochondrial oxoglutarate/malate protein 2carrier $\mathrm{N}$

NAD(P)H dehydrogenase NQO1_HUMA

[quinone] 1

Q9H8J5 MANSC1 46.8 -

Required for TMEM67 111.7 ciliary structure and function

Catalytic and SLC25A11 34.1 transporter activities

$\mathrm{N}$-acetyllactosaminide beta-

$1,3-\mathrm{N}-$ acetylglucosaminyltransferas $\mathrm{N}$

B3GN2_HUMA e 2

Q9NY97

B3GNT2 46.0 Catalytic activity

Nck-associated protein 1

NCKP1_HUMA $\mathrm{N}$

Q9Y2A7

NCKAP1

128.8

As component of the WAVE1 complex, required for

\begin{tabular}{|c|c|c|c|c|c|}
\hline & 10 & & & & $\begin{array}{l}\text { endocytic } \\
\text { trafficking and } \\
\text { signaling from } \\
\text { early endosomes }\end{array}$ \\
\hline Nesprin-1 & $\begin{array}{l}\text { SYNE1_HUMA } \\
\mathrm{N}\end{array}$ & Q8NF91 & SYNE1 & $\begin{array}{l}1011 . \\
1\end{array}$ & $\begin{array}{l}\text { Forms a linking } \\
\text { network } \\
\text { between } \\
\text { organelles and } \\
\text { the actin } \\
\text { cytoskeleton to } \\
\text { maintain the } \\
\text { subcellular }\end{array}$ \\
\hline
\end{tabular}


M. del Pilar Chantada-Vázquez, A. C. López, M. G. Vence, S. Vázquez-Estévez, B. Acea-Nebril, D. G. Calatayud, T. Jardiel, S. B. Bravo and C. Núñez, J. Proteomics, 2020, 212, 103581. DOI:

10.1016/j.jprot.2019.103581

Protein name

UniProt name Entry name Gene

Nuclear receptor coactivator NCOA6_HUMA Q14686
$6 \quad$ deadenylation
PAN2-PAN3_HUMAN Q58A45
complex subunit PAN3

Pentatricopeptide repeat-
containing protein $1, \mathrm{NTCD} 1$ _HUMA

mitochondrial

$075127 \quad$ PTCD1

PTCD1

NCOA6 219.1

PAN3

95.6

Mass
(kDa)

spatial

organization

Involved in the

coactivation of

the NF-kappa-B

pathway

Regulatory

subunit of the

poly(A)-nuclease

(PAN)

deadenylation

complex

Mitochondrial

protein

implicated in

negative

regulation of

leucine tRNA

78.8 levels, as well as negative

regulation of mitochondriaencoded proteins and cox activity

Acts as a positive

Phosphatidylcholine

translocator ABCB4

MDR3_HUMA

$\mathrm{N}$

P21439 ABCB4

141.5

regulator of biliary lipid secretion

1-phosphatidylinositol 4,5-

bisphosphate

PLCG2_HUMA

$\mathrm{N}$

P16885

PLCG2

147.8 Catalytic activity

phosphodiesterase gamma-2

Phospholipase D1

PLD1_HUMAN Q13393

PLD1

124.2 Catalytic activity

Polypeptide

$\mathrm{N}-$

acetylgalactosaminyltransfer

ase 3
$\mathrm{N}$
Q14435

GALNT3 72.6 Catalytic activity 
M. del Pilar Chantada-Vázquez, A. C. López, M. G. Vence, S. Vázquez-Estévez, B. Acea-Nebril, D. G. Calatayud, T. Jardiel, S. B. Bravo and C. Núñez, J. Proteomics, 2020, 212, 103581. DOI:

10.1016/j.jprot.2019.103581

Protein name

Protein salvador homolog 1

SAV1_HUMAN Q9H4B6

S10A7_HUMA

$\mathrm{N}$

S10A8_HUMA

$\mathrm{N}$

P05109

Protein S100-A8

Protein S100-A9

S10A9_HUMA

$\mathrm{N}$

P06702

S100A9

S100A8

10.8

Plays

a

prominent role

in the regulation

of inflammatory

processes and

immune

response

Plays

prominent role

in the regulation

13.2 of inflammatory

processes and

immune

response

Protein Z-dependent protease inhibitor

ZPI_HUMAN Q9UK55

Protein ZGRF1

ZGRF1_HUMA

$\mathrm{N}$

Q86YA3
SERPINA1

0

50.7

Enzyme

regulator activity

Zinc ion binding

that inhibits

factors $\mathrm{Xa}$ and

Xla of the

coagulation

cascade 
M. del Pilar Chantada-Vázquez, A. C. López, M. G. Vence, S. Vázquez-Estévez, B. Acea-Nebril, D. G. Calatayud, T. Jardiel, S. B. Bravo and C. Núñez, J. Proteomics, 2020, 212, 103581. DOI:

10.1016/j.jprot.2019.103581

Protein name

Protocadherin-12

Roundabout homolog 4

ROBO4_HUMA $\mathrm{N}$

PCD12_HUMA Q9NPG4 $\mathrm{N}$

UniProt name Entry name Gene

Mass

(kDa)

Cellular

adhesion

molecule that

plays an

important role

as a regulator of cell migration, probably via increasing cellcell adhesion

Mediates the inhibition of primary endothelial cell migration by Slit proteins

Serum amyloid A-2 protein

SAA2_HUMAN PODJI9

SAA2

13.5

Inflammatory response

Positive regulator of

Short coiled-coil protein SCOC_HUMAN Q9UIL1 SCOC 18.0 amino acid starvationinduced autophagy

Structural maintenance of chromosomes protein 6 SMC6_HUMAN Q96SB8 SMC6

126.3 Structural

Supervillin SVIL_HUMAN 095425 SVIL

247.7 Structural

Syncoilin SYNCI_HUMAN Q9H7C4 SYNC 55.3

Plays a supportive role in the efficient coupling of mechanical stress between the myofibril and fiber exterior

TBC1 domain family member TBCD9_HUMA 9

$\mathrm{N}$
TBC1D9 143.2 Acts as a GTPaseactivating 
M. del Pilar Chantada-Vázquez, A. C. López, M. G. Vence, S. Vázquez-Estévez, B. Acea-Nebril, D. G. Calatayud, T. Jardiel, S. B. Bravo and C. Núñez, J. Proteomics, 2020, 212, 103581. DOI:

10.1016/j.jprot.2019.103581

Protein name

Transportin-1

Tudor domain-containing TDRD5_HUMA protein 5

N

TNPO1_HUMA

$\mathrm{N}$

Q92973

TNPO1

UBA1

activating enzyme 1

UBA1_HUMAN P22314

modifier-

E3 ubiquitin-protein ligase MSL2

MSL2_HUMAN Q9HCI7 MSL2

Villin-like protein

VILL_HUMAN $015195 \quad$ VILL

Vitamin K-dependent protein C

PROC_HUMAN P04070 PROC

Zinc finger RNA-binding

protein

ZFR_HUMAN Q96KR1 ZFR

Zinc finger protein 99

ZNF99_HUMA

$\mathrm{N}$

A8MXY4 ZNF99
Mass
(kDa) Function

protein for Rab

family protein(s)

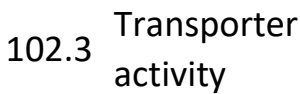

Acts via the piRNA metabolic process, which mediates the repression of transposable elements during meiosis

117.8 Catalytic activity

Component of histone

62.5 acetyltransferas e complex

$95.9 \begin{aligned} & \text { Tumor } \\ & \text { suppressor }\end{aligned}$

52.1 Catalytic activity Involved in the 117.0 nucleocytoplasm ic shuttling of STAU2

May be involved 100.8 in transcriptional regulation

The accession number, gene name, species (Human), molecular weight (kDa) and protein function were reported. 
M. del Pilar Chantada-Vázquez, A. C. López, M. G. Vence, S. Vázquez-Estévez, B. Acea-Nebril, D. G. Calatayud, T. Jardiel, S. B. Bravo and C. Núñez, J. Proteomics, 2020, 212, 103581. DOI:

\subsection{6/j.jprot.2019.103581}

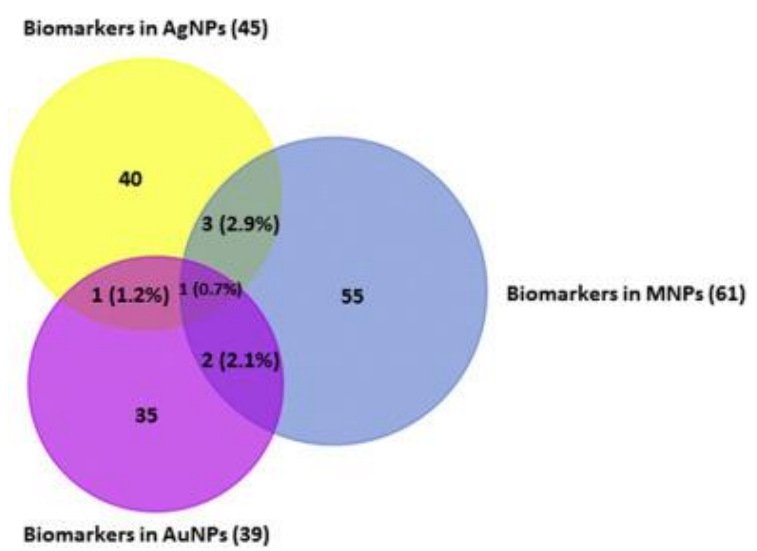

Fig. 3. Quantitative Venn diagrams showing the number of identified protein biomarkers found on the surface of the three different nanoparticles (color: black) and commonly found on the surface of AuNPs $(10.02 \pm 0.91), \operatorname{AgNPs}(9.73 \pm 1.70 \mathrm{~nm})$ and MNPs $(9.30 \pm 0.67 \mathrm{~nm})$ (color: grey).

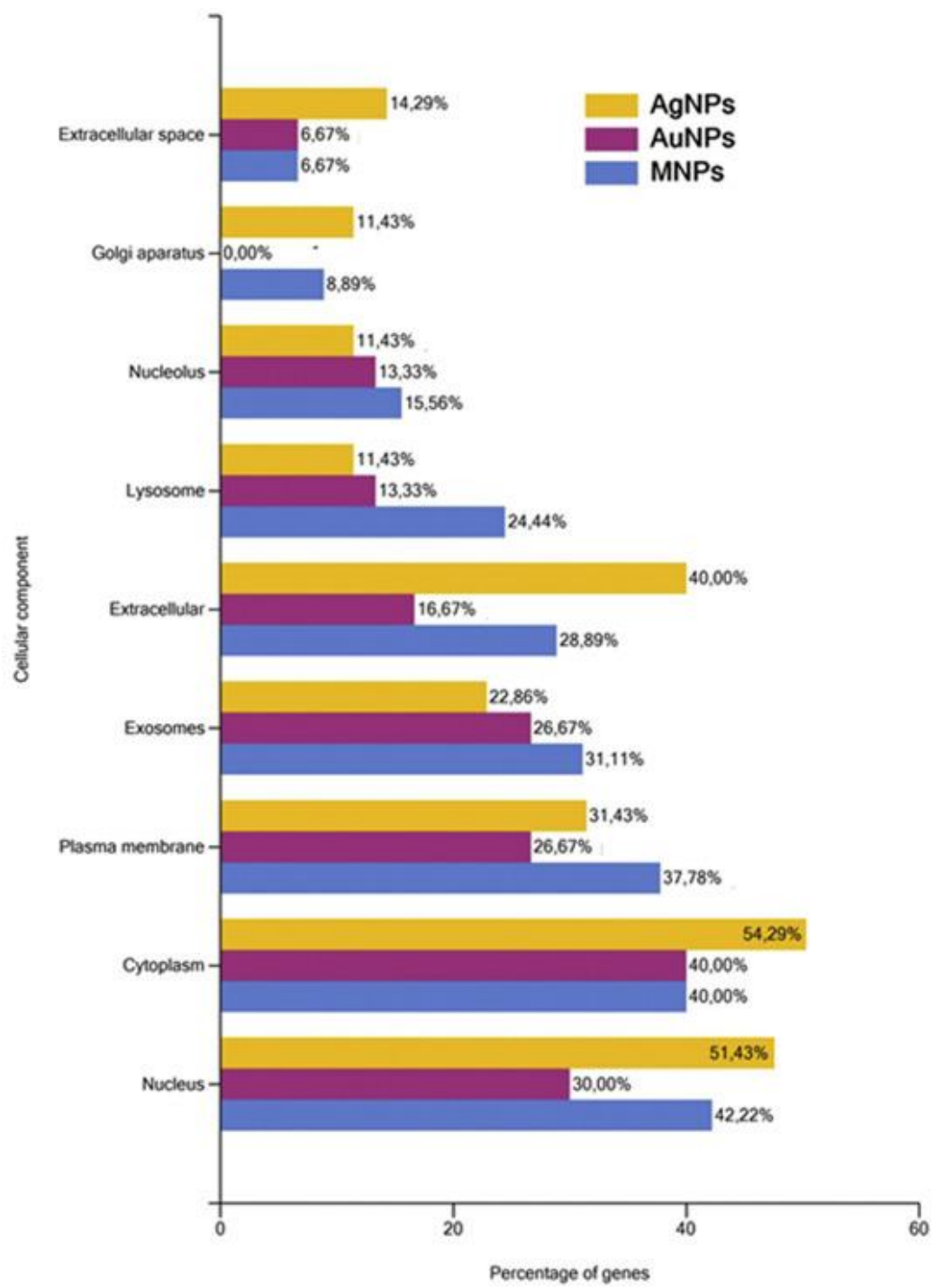

Fig. 4. Localization of the 39, 45 and 61 protein biomarkers found in the surface of AuNPs (10.02 \pm 0.91$)$, AgNPs $(9.73 \pm 1.70 \mathrm{~nm})$ and MNPs $(9.30 \pm 0.67 \mathrm{~nm})$, respectively, in the different cellular components. 
M. del Pilar Chantada-Vázquez, A. C. López, M. G. Vence, S. Vázquez-Estévez, B. Acea-Nebril, D. G. Calatayud, T. Jardiel, S. B. Bravo and C. Núñez, J. Proteomics, 2020, 212, 103581. DOI:

10.1016/j.jprot.2019.103581

Importantly, the GRF-type zinc finger domain-containing protein 1 (protein ZGRF1) was identified in the protein corona of AuNPs, AgNPs and MNPs after their incubation with the serum samples of all triple negative breast cancer patients. Zinc-finger proteins (ZNFs) are one of the most abundant groups of proteins and have a wide range of molecular functions. Given the wide variety of zinc-finger domains, ZNFs can interact with DNA, RNA, PAR (poly-ADP-ribose) and other proteins. Thus, ZNFs are involved in the regulation of several cellular processes. ZNFs are implicated in transcriptional regulation, ubiquitin-mediated protein degradation, signal transduction, actin targeting, DNA repair, cell migration, and numerous other processes [46]. Notably, overexpression of similar zinc finger proteins has been shown to promote cell growth and metastasis in laryngeal squamous cell carcinoma, glioma, non-small cell lung cancer, gastric cancer, oral squamous cell carcinoma, gallbladder cancer, and breast cancer [47], and also in triple negative breast cancers [48].

Matrix metalloproteinase-9 (MMP9) was identified in the protein corona of AuNPs and AgNPs after their incubation with the serum samples of all triple negative breast cancer patients. Members of the matrix metalloproteinase (MMP) family have been identified as poor prognosis markers for breast cancer patients and as drivers of many facets of the tumor phenotype in experimental models [49]. Studies of the pathological processes involved in tumor progression and metastasis revealed matrix metalloproteinases (MMPs) as prominent molecules engaged in shaping the tumor microenvironment and driving cancer progression and metastasis $[\underline{50}, \underline{51}]$. Mainly, MMP9 was investigated as a potential tumor marker in breast cancer [52]. MMP-9 is one of 70 genes in the Rosetta poor prognosis signature for breast cancer patients [53], the basis for the clinically implemented Mammaprint prognostic assay (Agendia Inc., Irvine, CA). MMP-9 was also highly expressed in node-positive tumors and the preoperative blood serum of patients, but MMP-9 activity was appreciably inhibited in blood serum samples collected after surgery.

Lebercilin and Immunoglobulin lambda variable 3-27 (LV327) were identified in the protein corona of AuNPs and MNPs after their incubation with the serum samples of all triple negative breast cancer patients. While the protein expression of lebercilin was observed in several tissue cancers like colorectal cancer, breast cancer, prostate cancer, lung cancer Human Protein Atlas, https://www.proteinatlas.org/ENSG00000157578-LCA5L/pathology), immunoglobulin free light chains as LV327 are biomarkers of poor prognosis in basal-like breast cancer and are potential targets in tumor-associated inflammation [54].

LINE-1 type transposase domain-containing protein 1 (LITD1), structural maintenance of chromosomes protein 6 (SMC6) and short coiled-coil protein (SCOC) were identified in the protein corona of AgNPs and MNPs after their incubation with the serum samples of all triple negative breast cancer patients.

L1TD1 is an RNA-binding protein that involved with self-renewal of undifferentiated human embryonic stem cells and cancer cell proliferation [55].

The structural maintenance of chromosomes (SMC) proteins are essential for successful chromosome transmission during replication and segregation of the genome in all organisms. SMC proteins function together with other proteins in a range of chromosomal 
M. del Pilar Chantada-Vázquez, A. C. López, M. G. Vence, S. Vázquez-Estévez, B. Acea-Nebril, D. G. Calatayud, T. Jardiel, S. B. Bravo and C. Núñez, J. Proteomics, 2020, 212, 103581. DOI:

10.1016/j.jprot.2019.103581

transactions, including chromosome condensation, sister-chromatid cohesion, recombination, DNA repair, and epigenetic silencing of gene expression. Notably, the protein expression of SMC6 was observed in different tissues as colorectal cancer, breast cancer, prostate cancer, lung cancer, and liver cancer (The Human Protein Atlas, https://www.proteinatlas.org/ENSG00000163029-SMC6/pathology). In humans, SCOC is required for autophagosome formation during amino acid starvation [ [56]; however, this relation with cancer is unknown until the moment.

\title{
3.3. Proteomic alterations in triple negative breast cancer serum revealed by SWATH-MS analysis
}

Label-free SWATH experiments were carried out on a Triple TOF 6600 mass spectrometer (SCIEX). After a comparison between the different groups of samples (controls and TNBC patients), it was observed a variation in the number of statistically significant proteins in the protein corona formed around the three different NPs: $10.02 \pm 0.91 \mathrm{~nm}$ gold nanoparticles (AuNPs), $9.73 \pm 1.70 \mathrm{~nm}$ silver nanoparticles (AgNPs) and $9.30 \pm 0.67 \mathrm{~nm}$ magnetic nanoparticles (MNPs) (see Table 5).

Table 5. Number of proteins identified by LC-MS/MS by SWATH analysis.

\author{
SWATH-MS \\ Library 180 \\ Samples \\ TNBC patients vs. controls (AuNPs) 48 ( $p$-value $\leq 0.05$ ) \\ TNBC patients vs. controls (AgNPs) 140 ( $p$-value $\leq 0.05)$ \\ TNBC patients vs. controls (MNPs) 57 ( $p$-value $\leq 0.05$ )
}

After the analysis of the protein corona formed around AuNPs (10.02 $\pm 0.91 \mathrm{~nm})$, a total of 177 non-redundant proteins were quantified, out of which 48 were found to be differentially regulated. 14 proteins had elevated expression, while 34 proteins showed down-regulation (see Table 6 ).

Table 6. Significant proteins $(p$-value $<0.05)$ in comparisons between triple negative breast cancer and controls after the analysis of the protein corona of AuNPs $(10.02 \pm 0.91 \mathrm{~nm})$.

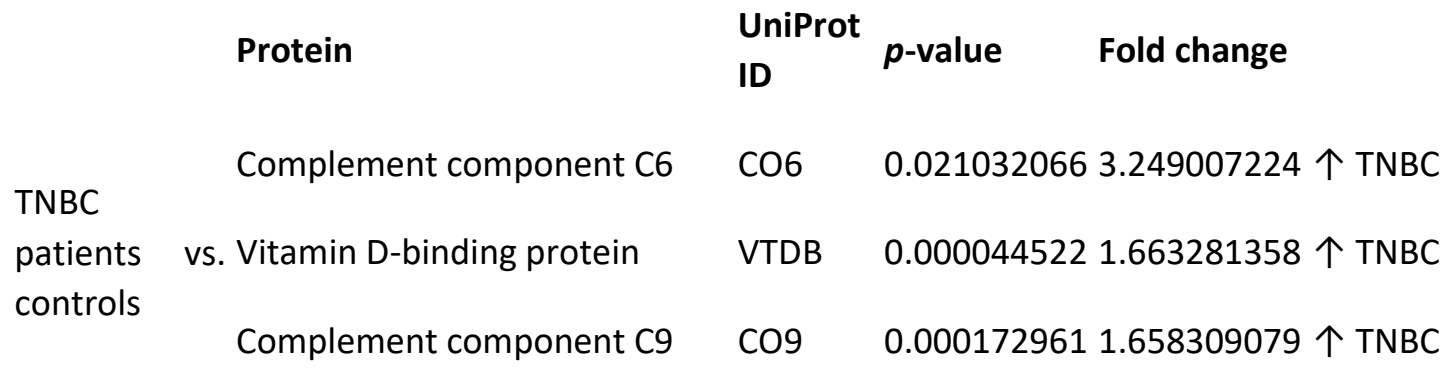


M. del Pilar Chantada-Vázquez, A. C. López, M. G. Vence, S. Vázquez-Estévez, B. Acea-Nebril, D.

G. Calatayud, T. Jardiel, S. B. Bravo and C. Núñez, J. Proteomics, 2020, 212, 103581. DOI:

10.1016/j.jprot.2019.103581

\begin{tabular}{|c|c|c|c|c|}
\hline Protein & $\begin{array}{l}\text { UniProt } \\
\text { ID }\end{array}$ & $p$-value & Fold change & \\
\hline Complement C4-A & CO4A & 0.003482887 & 1.525866959 & $\uparrow \mathrm{TNBC}$ \\
\hline Complement C3 & $\mathrm{CO} 3$ & 0.000115208 & 1.451520626 & 个 TNBC \\
\hline Plasminogen & PLMN & 0.005392898 & 1.329388215 & 个 TNBC \\
\hline Vitronectin & VTNC & 0.004766057 & 1.282037959 & 个 TNBC \\
\hline Apolipoprotein L1 & APOL1 & 0.022535013 & 1.251913563 & $\uparrow \mathrm{TNBC}$ \\
\hline Afamin & AFAM & 0.020811026 & 1.248070740 & 个 TNBC \\
\hline Complement factor $\mathrm{H}$ & $\mathrm{CFAH}$ & 0.020861177 & 1.204471284 & $\uparrow \mathrm{TNBC}$ \\
\hline Complement C5 & $\mathrm{CO5}$ & 0.016073885 & 1.185058578 & 个 TNBC \\
\hline Serum albumin & ALBU & 0.004803944 & 1.172992995 & 个 TNBC \\
\hline Kininogen-1 & KNG1 & 0.024754757 & 1.167133709 & $\uparrow \mathrm{TNBC}$ \\
\hline Galectin-3-binding protein & LG3BP & 0.030403083 & 1.088223023 & 个 TNBC \\
\hline Glutathione peroxidase 3 & GPX3 & 0.01510168 & 7.16326536 & $\begin{array}{l}\uparrow \\
\text { CONTROL }\end{array}$ \\
\hline $\begin{array}{l}\text { Immunoglobulin heavy variable } \\
\text { 5-51 }\end{array}$ & HV551 & 0.02782821 & 4.90904368 & $\begin{array}{l}\uparrow \\
\text { CONTROL }\end{array}$ \\
\hline $\begin{array}{l}\text { Immunoglobulin } \\
\text { constant mu }\end{array}$ & IGHM & 0.04111454 & 4.42849357 & $\begin{array}{l}\uparrow \\
\text { CONTROL }\end{array}$ \\
\hline Apolipoprotein C-I & APOC1 & 0.00460538 & 4.09989381 & $\begin{array}{l}\uparrow \\
\text { CONTROL }\end{array}$ \\
\hline $\begin{array}{l}\text { Immunoglobulin } \\
\text { variable 3-9 }\end{array}$ & LV39 & 0.0394842 & 3.35634858 & $\begin{array}{l}\uparrow \\
\text { CONTROL }\end{array}$ \\
\hline Apolipoprotein D & APOD & 0.04050732 & 3.22034685 & $\begin{array}{l}\uparrow \\
\text { CONTROL }\end{array}$ \\
\hline $\begin{array}{l}\text { Immunoglobulin } \\
\text { constant alpha } 1\end{array}$ & IGHA1 & 0.00960489 & 3.19128417 & $\begin{array}{l}\uparrow \\
\text { CONTROL }\end{array}$ \\
\hline $\begin{array}{l}\text { Immunoglobulin kappa variable } \\
2-29\end{array}$ & KV229 & 0.00334596 & 2.48673552 & $\begin{array}{l}\uparrow \\
\text { CONTROL }\end{array}$ \\
\hline
\end{tabular}


M. del Pilar Chantada-Vázquez, A. C. López, M. G. Vence, S. Vázquez-Estévez, B. Acea-Nebril, D.

G. Calatayud, T. Jardiel, S. B. Bravo and C. Núñez, J. Proteomics, 2020, 212, 103581. DOI:

10.1016/j.jprot.2019.103581

\begin{tabular}{|c|c|c|c|c|}
\hline Protein & $\begin{array}{l}\text { UniProt } \\
\text { ID }\end{array}$ & $p$-value & Fold change & \\
\hline $\begin{array}{l}\text { Immunoglobulin } \\
\text { constant alpha } 2\end{array}$ & IGHA2 & 0.02785381 & 2.43044159 & $\begin{array}{l}\uparrow \\
\text { CONTROL }\end{array}$ \\
\hline $\begin{array}{l}\text { Inter-alpha-trypsin } \\
\text { heavy chain } \mathrm{H} 4\end{array}$ & $\mathrm{ITIH} 4$ & 0.02521756 & 2.41781135 & $\begin{array}{l}\uparrow \\
\text { CONTROL }\end{array}$ \\
\hline $\begin{array}{l}\text { Immunoglobulin } \\
\text { variable 4-69 }\end{array}$ & LV469 & 0.00833282 & 2.37374475 & $\begin{array}{l}\uparrow \\
\text { CONTROL }\end{array}$ \\
\hline $\begin{array}{l}\text { Apolipoprotein(a) OS=Homo } \\
\text { sapiens }\end{array}$ & APOA & 0.03681681 & 2.12362227 & $\begin{array}{l}\uparrow \\
\text { CONTROL }\end{array}$ \\
\hline $\begin{array}{l}\text { Pigment epithelium-derived } \\
\text { factor }\end{array}$ & PEDF & 0.00858685 & 1.94114234 & $\begin{array}{l}\uparrow \\
\text { CONTROL }\end{array}$ \\
\hline Alpha-2-macroglobulin & A2MG & 0.00477503 & 1.9190963 & $\begin{array}{l}\uparrow \\
\text { CONTROL }\end{array}$ \\
\hline Hemoglobin subunit beta & HBB & 0.00500101 & 1.90068671 & $\begin{array}{l}\uparrow \\
\text { CONTROL }\end{array}$ \\
\hline CD5 antigen-like & CD5L & 0.0397185 & 1.7759815 & $\begin{array}{l}\uparrow \\
\text { CONTROL }\end{array}$ \\
\hline Serum amyloid A-4 protein & SAA4 & 0.04115058 & 1.77144695 & $\begin{array}{l}\uparrow \\
\text { CONTROL }\end{array}$ \\
\hline Tetranectin & TETN & 0.01611908 & 1.7097494 & $\begin{array}{l}\uparrow \\
\text { CONTROL }\end{array}$ \\
\hline Apolipoprotein A-II & APOA2 & 0.01467561 & 1.67488772 & $\begin{array}{l}\uparrow \\
\text { CONTROL }\end{array}$ \\
\hline $\begin{array}{l}\text { Inter-alpha-trypsin } \\
\text { heavy chain } \mathrm{H} 2\end{array}$ & $\mathrm{ITIH} 2$ & 0.00096553 & 1.61898708 & $\begin{array}{l}\uparrow \\
\text { CONTROL }\end{array}$ \\
\hline Carboxypeptidase B2 & CBPB2 & 0.00728968 & 1.46619249 & $\begin{array}{l}\uparrow \\
\text { CONTROL }\end{array}$ \\
\hline Transthyretin & TTHY & 0.04987991 & 1.45277849 & $\begin{array}{l}\uparrow \\
\text { CONTROL }\end{array}$ \\
\hline $\begin{array}{l}\text { Complement } \\
\text { subcomponent-like protein }\end{array}$ & C1 & 0.03887632 & 1.43784936 & $\begin{array}{l}\uparrow \\
\text { CONTROL }\end{array}$ \\
\hline
\end{tabular}


M. del Pilar Chantada-Vázquez, A. C. López, M. G. Vence, S. Vázquez-Estévez, B. Acea-Nebril, D. G. Calatayud, T. Jardiel, S. B. Bravo and C. Núñez, J. Proteomics, 2020, 212, 103581. DOI:

10.1016/j.jprot.2019.103581

\begin{tabular}{|c|c|c|c|c|}
\hline Protein & $\begin{array}{l}\text { UniProt } \\
\text { ID }\end{array}$ & $p$-value & Fold change & \\
\hline $\begin{array}{l}\text { Inter-alpha-trypsin inhibitor } \\
\text { heavy chain } \mathrm{H} 1\end{array}$ & $\mathrm{ITIH} 1$ & 0.00031251 & 1.41502216 & $\begin{array}{l}\uparrow \\
\text { CONTROL }\end{array}$ \\
\hline $\begin{array}{l}\text { Serum } \\
\text { paraoxonase/arylesterase } 1\end{array}$ & PON1 & 0.00142352 & 1.40629048 & $\begin{array}{l}\uparrow \\
\text { CONTROL }\end{array}$ \\
\hline Apolipoprotein F & APOF & 0.03956903 & 1.39106396 & $\begin{array}{l}\uparrow \\
\text { CONTROL }\end{array}$ \\
\hline Apolipoprotein M & APOM & 0.00064927 & 1.36179665 & $\begin{array}{l}\uparrow \\
\text { CONTROL }\end{array}$ \\
\hline Apolipoprotein A-I & APOA1 & 0.02341567 & 1.34721575 & $\begin{array}{l}\uparrow \\
\text { CONTROL }\end{array}$ \\
\hline Serotransferrin & TRFE & 0.0020036 & 1.31516423 & $\begin{array}{l}\uparrow \\
\text { CONTROL }\end{array}$ \\
\hline Selenoprotein $\mathrm{P}$ & SEPP1 & 0.00426885 & 1.30905254 & $\begin{array}{l}\uparrow \\
\text { CONTROL }\end{array}$ \\
\hline $\begin{array}{l}\text { Mannan-binding lectin serine } \\
\text { protease } 1\end{array}$ & MASP1 & 0.03643268 & 1.29206286 & $\begin{array}{l}\uparrow \\
\text { CONTROL }\end{array}$ \\
\hline Carboxypeptidase $\mathrm{N}$ subunit 2 & CPN2 & 0.03700623 & 1.28514087 & $\begin{array}{l}\uparrow \\
\text { CONTROL }\end{array}$ \\
\hline Protein AMBP & AMBP & 0.0084045 & 1.22749917 & $\begin{array}{l}\uparrow \\
\text { CONTROL }\end{array}$ \\
\hline Plasma protease C1 inhibitor & IC1 & 0.04106727 & 1.2095684 & $\begin{array}{l}\uparrow \\
\text { CONTROL }\end{array}$ \\
\hline
\end{tabular}

In the case of the protein corona formed around AgNPs $(9.73 \pm 1.70 \mathrm{~nm})$, a total of 176 non-redundant proteins were quantified, out of which 140 were found to be differentially regulated. 64 proteins had elevated expression, while 76 proteins showed downregulation (see Table 7). 
M. del Pilar Chantada-Vázquez, A. C. López, M. G. Vence, S. Vázquez-Estévez, B. Acea-Nebril, D. G. Calatayud, T. Jardiel, S. B. Bravo and C. Núñez, J. Proteomics, 2020, 212, 103581. DOI:

10.1016/j.jprot.2019.103581

Table 7. Significant proteins ( $p$-value $<0.05$ ) in comparisons between triple negative breast cancer and controls after the analysis of the protein corona of AgNPs $(9.73 \pm 1.70 \mathrm{~nm})$.

\begin{tabular}{|c|c|c|c|}
\hline Protein & $\begin{array}{l}\text { UniProt } \\
\text { ID }\end{array}$ & $p$-value & $\begin{array}{l}\text { Fold } \\
\text { change }\end{array}$ \\
\hline C-reactive protein & CRP & 0.00550613 & 34.84567669 个 TNBC \\
\hline Histidine-rich glycoprotein & HRG & $3.22 \mathrm{E}-09$ & 3.93436379 个 TNBC \\
\hline Complement component C9 & co9 & $6.28 \mathrm{E}-08$ & $3.56825414 \uparrow$ TNBC \\
\hline Complement C3 & $\mathrm{CO} 3$ & $1.95 \mathrm{E}-08$ & $3.03698879 \uparrow \mathrm{TNBC}$ \\
\hline Complement factor B & CFAB & 4.13E-09 & $2.83840576 \uparrow$ TNBC \\
\hline $\begin{array}{l}\text { Immunoglobulin kappa variable 2- } \\
24\end{array}$ & KV224 & 0.00067261 & L 2.77717871 个 TNBC \\
\hline Ficolin-3 & FCN3 & $7.79 E-08$ & $2.73769215 \uparrow \mathrm{TNBC}$ \\
\hline $\begin{array}{l}\text { Immunoglobulin kappa variable 1- } \\
13\end{array}$ & KV113 & 0.00613408 & 2.71041552 个 TNBC \\
\hline IgGFc-binding protein & FCGBP & 0.00010163 & 2.70272053 个 TNBC \\
\hline $\begin{array}{l}\text { Phosphatidylinositol-glycan- } \\
\text { specific phospholipase D PE=1 } \\
S V=3\end{array}$ & PHLD & 0.00305474 & 2.66489178 个 TNBC \\
\hline Coagulation factor XIII B chain & F13B & $2.66 \mathrm{E}-07$ & 2.60635841 个 TNBC \\
\hline Fetuin-B & FETUB & $1.50 \mathrm{E}-06$ & $2.55082102 \uparrow \mathrm{TNBC}$ \\
\hline Apolipoprotein L1 & APOL1 & $2.53 \mathrm{E}-10$ & $2.52932257 \uparrow \mathrm{TNBC}$ \\
\hline Serum albumin & ALBU & 4.46E-09 & $2.51568102 \uparrow \mathrm{TNBC}$ \\
\hline $\begin{array}{l}\text { Insulin-like growth factor-binding } \\
\text { protein complex acid labile } \\
\text { subunit }\end{array}$ & ALS & 4.46E-09 & 2.49955167 个 TNBC \\
\hline $\begin{array}{l}\text { Inter-alpha-trypsin inhibitor heavy } \\
\text { chain H3 }\end{array}$ & $\mathrm{ITIH} 3$ & 7.30E-07 & $2.38250842 \uparrow \mathrm{TNBC}$ \\
\hline Complement factor I & CFAI & $1.02 \mathrm{E}-07$ & 2.3647495 个 TNBC \\
\hline Complement factor $\mathrm{H}$ & $\mathrm{CFAH}$ & 4.83E-09 & $2.35326116 \uparrow$ TNBC \\
\hline Vitronectin & VTNC & 1.40E-09 & 2.31946741 个 TNBC \\
\hline
\end{tabular}


M. del Pilar Chantada-Vázquez, A. C. López, M. G. Vence, S. Vázquez-Estévez, B. Acea-Nebril, D.

G. Calatayud, T. Jardiel, S. B. Bravo and C. Núñez, J. Proteomics, 2020, 212, 103581. DOI:

10.1016/j.jprot.2019.103581

\begin{tabular}{|c|c|c|c|}
\hline Protein & $\begin{array}{l}\text { UniProt } \\
\text { ID }\end{array}$ & $p$-value & $\begin{array}{l}\text { Fold } \\
\text { change }\end{array}$ \\
\hline C4b-binding protein alpha chain & C4BPA & 0.00011973 & 2.28632913 个 TNBC \\
\hline Hyaluronan-binding protein 2 & HABP2 & $3.29 \mathrm{E}-07$ & 2.28034134 个 TNBC \\
\hline Plasminogen & PLMN & 7.79E-05 & 2.23378207 个 TNBC \\
\hline Keratin type II cytoskeletal 1 & $\mathrm{~K} 2 \mathrm{C} 1$ & 0.00022394 & 2.20416961 个 TNBC \\
\hline Kininogen-1 & KNG1 & $1.18 \mathrm{E}-08$ & 2.19276786 个 TNBC \\
\hline Fibronectin & FINC & $3.36 \mathrm{E}-08$ & 2.08858855 个 TNBC \\
\hline Complement C5 & $\mathrm{CO} 5$ & $2.42 \mathrm{E}-08$ & $2.01278029 \uparrow \mathrm{TNBC}$ \\
\hline $\begin{array}{l}\text { Complement } \mathrm{C} 1 \mathrm{q} \text { subcomponent } \\
\text { subunit C }\end{array}$ & it HUMAN & $4.55 \mathrm{E}-05$ & 2.01080564 个 TNBC \\
\hline Apolipoprotein A-IV & APOA4 & 4.61E-06 & 2.00364799 个 TNBC \\
\hline Keratin type I cytoskeletal 10 & $\mathrm{~K} 1 \mathrm{C} 10$ & 0.00259975 & $1.97893282 \uparrow \mathrm{TNBC}$ \\
\hline Tetranectin & TETN & 4.94E-05 & 1.95250374 个 TNBC \\
\hline Clusterin & CLUS & $1.82 \mathrm{E}-06$ & 1.9173471 个 TNBC \\
\hline $\begin{array}{lll}\text { Complement component } & \mathrm{C} 8 \\
\text { gamma chain } & & \end{array}$ & $\mathrm{CO} 8 \mathrm{G}$ & $6.29 E-06$ & 1.89453705 个 TNBC \\
\hline Serotransferrin & TRFE & 4.33E-05 & 1.8939175 个 TNBC \\
\hline Complement C4-B & $\mathrm{CO} 4 \mathrm{~B}$ & 0.03028632 & 1.89103397 个 TNBC \\
\hline $\begin{array}{l}\text { Complement C1q subcomponent } \\
\text { subunit B }\end{array}$ & t $\mathrm{C} 1 \mathrm{QB}$ & 0.00018878 & $1.88786101 \uparrow \mathrm{TNBC}$ \\
\hline Plasma kallikrein & KLKB1 & $2.85 \mathrm{E}-06$ & $1.88182482 \uparrow \mathrm{TNBC}$ \\
\hline Galectin-3-binding protein & LG3BP & $1.76 \mathrm{E}-09$ & 1.85166575 个 TNBC \\
\hline Alpha-2-HS-glycoprotein & FETUA & $1.70 \mathrm{E}-06$ & $1.82851516 \uparrow$ TNBC \\
\hline $\begin{array}{l}\text { Complement } \mathrm{C} 1 \mathrm{q} \text { subcomponent } \\
\text { subunit } \mathrm{A}\end{array}$ & t C1QA & 0.00028866 & 1.80691958 个 TNBC \\
\hline Prothrombin & THRB & 0.0030656 & 1.68707742 个 TNBC \\
\hline Retinol-binding protein 4 & RET4 & $5.98 \mathrm{E}-06$ & 1.65111784 个 TNBC \\
\hline
\end{tabular}


M. del Pilar Chantada-Vázquez, A. C. López, M. G. Vence, S. Vázquez-Estévez, B. Acea-Nebril, D.

G. Calatayud, T. Jardiel, S. B. Bravo and C. Núñez, J. Proteomics, 2020, 212, 103581. DOI:

10.1016/j.jprot.2019.103581

\begin{tabular}{|c|c|c|c|}
\hline Protein & $\begin{array}{l}\text { UniProt } \\
\text { ID }\end{array}$ & $p$-value & $\begin{array}{l}\text { Fold } \\
\text { change }\end{array}$ \\
\hline $\begin{array}{l}\text { Carboxypeptidase } \mathrm{N} \text { catalytic } \\
\text { chain }\end{array}$ & CBPN & 0.00562324 & 41.62654965 个 TNBC \\
\hline $\begin{array}{l}\text { Complement component } \mathrm{C} 8 \text { beta } \\
\text { chain }\end{array}$ & $\mathrm{CO} B \mathrm{~B}$ & 0.00298689 & 91.58131021 个 TNBC \\
\hline Sex hormone-binding globulin & SHBG & 0.04298875 & 51.5528487 个 TNBC \\
\hline Serum amyloid P-component & SAMP & 0.00436056 & 61.55023657 个 TNBC \\
\hline Zinc-alpha-2-glycoprotein & ZA2G & 0.00133379 & 91.54906716 个 TNBC \\
\hline Beta-2-glycoprotein 1 & $\mathrm{APOH}$ & 0.00192644 & 41.53648273 个 TNBC \\
\hline Vitamin K-dependent protein S & PROS & 1.47E-06 & 1.52146296 个 TNBC \\
\hline Complement C4-A & CO4A & 0.00378789 & 91.50875703 个 TNBC \\
\hline $\begin{array}{l}\text { Mannan-binding lectin serine } \\
\text { protease } 1\end{array}$ & MASP1 & 0.00057947 & 71.49286664 个 TNBC \\
\hline Complement C2 & $\mathrm{CO} 2$ & $1.04 \mathrm{E}-05$ & $1.48927332 \uparrow \mathrm{TNBC}$ \\
\hline Coagulation factor $X$ & FA10 & 0.00022691 & 11.47652463 个 TNBC \\
\hline Complement $\mathrm{C} 1 \mathrm{r}$ subcomponent & C1R & 0.03355753 & 31.46634915 个 TNBC \\
\hline Alpha-1-acid glycoprotein 2 & A1AG2 & 0.04347799 & 91.46608046 个 TNBC \\
\hline Antithrombin-III & ANT3 & 0.00109057 & $71.45858581 \uparrow \mathrm{TNBC}$ \\
\hline Afamin & AFAM & 0.02956547 & 71.42380083 个 TNBC \\
\hline Vitamin D-binding protein & VTDB & 0.00689951 & 11.40641874 个 TNBC \\
\hline Hemopexin & HEMO & 0.00014568 & 1.38633651 个 TNBC \\
\hline Carboxypeptidase $\mathrm{N}$ subunit 2 & CPN2 & 0.03697862 & $1.36334001 \uparrow \mathrm{TNBC}$ \\
\hline Protein AMBP & AMBP & 0.0013811 & 1.32566307 个 TNBC \\
\hline Apolipoprotein E & APOE & 0.00068645 & 1.28506343 个 TNBC \\
\hline Attractin & ATRN & 0.0072892 & $1.27421822 \uparrow \mathrm{TNBC}$ \\
\hline $\begin{array}{l}\mathrm{N} \text {-acetylmuramoyl-L-alanine } \\
\text { amidase }\end{array}$ & PGRP2 & 0.00138778 & 31.23991258 个 TNBC \\
\hline
\end{tabular}


M. del Pilar Chantada-Vázquez, A. C. López, M. G. Vence, S. Vázquez-Estévez, B. Acea-Nebril, D.

G. Calatayud, T. Jardiel, S. B. Bravo and C. Núñez, J. Proteomics, 2020, 212, 103581. DOI:

10.1016/j.jprot.2019.103581

\begin{tabular}{|c|c|c|c|c|}
\hline Protein & $\begin{array}{l}\text { UniProt } \\
\text { ID }\end{array}$ & $p$-value & $\begin{array}{l}\text { Fold } \\
\text { change }\end{array}$ & \\
\hline Apolipoprotein M & APOM & 0.01360078 & 1.23954254 & 个 TNBC \\
\hline $\begin{array}{l}\text { Immunoglobulin heavy variable } 3 \text { - } \\
15\end{array}$ & HV315 & $4.18 \mathrm{E}-06$ & 75.3967905 & $\begin{array}{l}\uparrow \\
\text { CONTROL }\end{array}$ \\
\hline $\begin{array}{l}\text { Immunoglobulin heavy constant, } \\
\text { gamma } 1\end{array}$ & IGHGI & $1.34 \mathrm{E}-07$ & 42.3987588 & $\begin{array}{l}\uparrow \\
\text { CONTROL }\end{array}$ \\
\hline Alpha-1-antichymotrypsin & AACT & $6.14 \mathrm{E}-10$ & 40.3625379 & $\begin{array}{l}\uparrow \\
\text { CONTROL }\end{array}$ \\
\hline $\begin{array}{l}\text { Immunoglobulin heavy variable 3- } \\
73\end{array}$ & HV373 & $6.06 \mathrm{E}-07$ & 37.7464233 & $\begin{array}{l}\uparrow \\
\text { CONTROL }\end{array}$ \\
\hline $\begin{array}{l}\text { Immunoglobulin heavy constant, } \\
\text { gamma } 3\end{array}$ & IGI & $3.68 \mathrm{E}-06$ & 36.0478431 & $\begin{array}{l}\uparrow \\
\text { CONTROL }\end{array}$ \\
\hline Ceruloplasmin & CERU & $2.42 \mathrm{E}-09$ & 33.0108942 & $\begin{array}{l}\uparrow \\
\text { CONTROL }\end{array}$ \\
\hline $\begin{array}{l}\text { Immunoglobulin heavy constant, } \\
\text { gamma } 2\end{array}$ & IGH & $1.72 \mathrm{E}-06$ & 32.3391318 & $\begin{array}{l}\uparrow \\
\text { CONTROL }\end{array}$ \\
\hline Alpha-1-antitrypsin & A1AT & $1.14 \mathrm{E}-10$ & 28.6542019 & $\begin{array}{l}\uparrow \\
\text { CONTROL }\end{array}$ \\
\hline $\begin{array}{l}\text { Immunoglobulin heavy constant } \\
\mathrm{mu}\end{array}$ & IGHM & 7.89E-05 & 26.3705332 & $\begin{array}{l}\uparrow \\
\text { CONTROL }\end{array}$ \\
\hline Corticosteroid-binding globulin & CBG & 1.19E-09 & 25.9868345 & $\begin{array}{l}\uparrow \\
\text { CONTROL }\end{array}$ \\
\hline $\begin{array}{l}\text { Immunoglobulin heavy constant, } \\
\text { gamma } 4\end{array}$ & IGHG4 & 0.00011456 & 521.9488461 & $\begin{array}{l}\uparrow \\
\text { CONTROL }\end{array}$ \\
\hline Cholinesterase & CHLE & $1.48 \mathrm{E}-08$ & 21.7678062 & $\begin{array}{l}\uparrow \\
\text { CONTROL }\end{array}$ \\
\hline $\begin{array}{l}\text { Immunoglobulin kappa variable 4- } \\
1\end{array}$ & KV401 & $2.21 \mathrm{E}-07$ & 20.676772 & $\begin{array}{l}\uparrow \\
\text { CONTROL }\end{array}$ \\
\hline $\begin{array}{l}\text { Immunoglobulin heavy variable 4- } \\
59\end{array}$ & HV459 & $4.18 \mathrm{E}-08$ & 19.791237 & $\begin{array}{l}\uparrow \\
\text { CONTROL }\end{array}$ \\
\hline $\begin{array}{l}\text { Immunoglobulin heavy var } \\
30-5\end{array}$ & $\mathrm{HV} 3$ & $1.61 \mathrm{E}-07$ & 18.8319962 & $\begin{array}{l}\uparrow \\
\text { CONTRO }\end{array}$ \\
\hline
\end{tabular}


M. del Pilar Chantada-Vázquez, A. C. López, M. G. Vence, S. Vázquez-Estévez, B. Acea-Nebril, D.

G. Calatayud, T. Jardiel, S. B. Bravo and C. Núñez, J. Proteomics, 2020, 212, 103581. DOI:

10.1016/j.jprot.2019.103581

\begin{tabular}{|c|c|c|c|c|}
\hline Protein & $\begin{array}{l}\text { UniProt } \\
\text { ID }\end{array}$ & $p$-value & $\begin{array}{l}\text { Fold } \\
\text { change }\end{array}$ & \\
\hline $\begin{array}{l}\text { Immunoglobulin lambda variable } \\
1-47\end{array}$ & LV147 & $6.19 \mathrm{E}-05$ & 18.715722 & $\begin{array}{l}\uparrow \\
\text { CONTROL }\end{array}$ \\
\hline $\begin{array}{l}\text { Immunoglobulin lambda variable } \\
8-61\end{array}$ & LV861 & $2.74 \mathrm{E}-08$ & 18.5700233 & $\begin{array}{l}\uparrow \\
\text { CONTROL }\end{array}$ \\
\hline $\begin{array}{l}\text { Immunoglobulin kappa variable 6- } \\
21\end{array}$ & KV621 & 0.0062062 & 16.6110906 & $\begin{array}{l}\uparrow \\
\text { CONTROL }\end{array}$ \\
\hline $\begin{array}{l}\text { Immunoglobulin heavy variable 3- } \\
49\end{array}$ & HV349 & $2.43 \mathrm{E}-08$ & 16.3703203 & $\begin{array}{l}\uparrow \\
\text { CONTROL }\end{array}$ \\
\hline Immunoglobulin kappa constant & IGKC & 2.49E-06 & 15.6449675 & $\begin{array}{l}\uparrow \\
\text { CONTROL }\end{array}$ \\
\hline $\begin{array}{l}\text { Immunoglobulin lambda constant } \\
3\end{array}$ & IGLC3 & $1.61 \mathrm{E}-05$ & 15.2226153 & $\begin{array}{l}\uparrow \\
\text { CONTROL }\end{array}$ \\
\hline $\begin{array}{l}\text { MMS19 nucleotide excision repair } \\
\text { protein homolog }\end{array}$ & MMS19 & 0.01743218 & 15.0005868 & $\begin{array}{l}\uparrow \\
\text { CONTROL }\end{array}$ \\
\hline $\begin{array}{l}\text { Immunoglobulin kappa variable 3- } \\
20\end{array}$ & KV320 & 5.98E-09 & 14.9565997 & $\begin{array}{l}\uparrow \\
\text { CONTROL }\end{array}$ \\
\hline $\begin{array}{l}\text { Immunoglobulin kappa variable 3- } \\
15\end{array}$ & KV315 & 4.41E-09 & 13.7845573 & $\begin{array}{l}\uparrow \\
\text { CONTROL }\end{array}$ \\
\hline $\begin{array}{l}\text { Immunoglobulin lambda-like } \\
\text { polypeptide } 1\end{array}$ & IGLL1 & $9.67 \mathrm{E}-08$ & 11.9419924 & $\begin{array}{l}\uparrow \\
\text { CONTROL }\end{array}$ \\
\hline $\begin{array}{l}\text { Immunoglobulin lambda variable } \\
3-9\end{array}$ & LV39 & $4.22 \mathrm{E}-07$ & 11.8083139 & $\begin{array}{l}\uparrow \\
\text { CONTROL }\end{array}$ \\
\hline $\begin{array}{l}\text { Immunoglobulin heavy variable 5- } \\
51\end{array}$ & HV551 & $4.24 \mathrm{E}-07$ & 11.4284904 & $\begin{array}{l}\uparrow \\
\text { CONTROL }\end{array}$ \\
\hline $\begin{array}{l}\text { Immunoglobulin kappa variable 3- } \\
11\end{array}$ & KV311 & $5.08 \mathrm{E}-09$ & 11.3796551 & $\begin{array}{l}\uparrow \\
\text { CONTROL }\end{array}$ \\
\hline $\begin{array}{l}\text { Immunoglobulin kappa variable 1- } \\
33\end{array}$ & KV133 & $7.64 \mathrm{E}-07$ & 11.2884931 & $\begin{array}{l}\uparrow \\
\text { CONTROL }\end{array}$ \\
\hline $\begin{array}{l}\text { Immunoglobulin heavy constant } \\
\text { alpha } 2\end{array}$ & & $6.08 \mathrm{E}$ & 10.9418774 & $\begin{array}{l}\uparrow \\
\text { CONTROL }\end{array}$ \\
\hline
\end{tabular}


M. del Pilar Chantada-Vázquez, A. C. López, M. G. Vence, S. Vázquez-Estévez, B. Acea-Nebril, D. G. Calatayud, T. Jardiel, S. B. Bravo and C. Núñez, J. Proteomics, 2020, 212, 103581. DOI:

10.1016/j.jprot.2019.103581

\begin{tabular}{|c|c|c|c|c|}
\hline Protein & $\begin{array}{l}\text { UniProt } \\
\text { ID }\end{array}$ & $p$-value & $\begin{array}{l}\text { Fold } \\
\text { change }\end{array}$ & \\
\hline $\begin{array}{l}\text { Immunoglobulin } \\
\text { polypeptide } 5 \mathrm{~V}=2\end{array}$ & IGLL5 & $9.57 \mathrm{E}-05$ & 10.7682004 & $\begin{array}{l}\uparrow \\
\text { CONTROL }\end{array}$ \\
\hline Angiotensinogen & ANGT & $3.42 \mathrm{E}-11$ & 8.97430276 & $\begin{array}{l}\uparrow \\
\text { CONTROL }\end{array}$ \\
\hline Pigment epithelium-derived factor & PEDF & $8.81 \mathrm{E}-10$ & 8.87937962 & $\begin{array}{l}\uparrow \\
\text { CONTROL }\end{array}$ \\
\hline $\begin{array}{l}\text { Immunoglobulin lambda variable } \\
7-43\end{array}$ & LV743 & $3.62 \mathrm{E}-06$ & 8.19552518 & $\begin{array}{l}\uparrow \\
\text { CONTROL }\end{array}$ \\
\hline Hemoglobin subunit alpha & HBA & 0.0003338 & 7.79643124 & $\begin{array}{l}\uparrow \\
\text { CONTROL }\end{array}$ \\
\hline $\begin{array}{l}\text { Immunoglobulin heavy constant } \\
\text { alpha } 1\end{array}$ & IGHA1 & $1.48 \mathrm{E}-07$ & 7.66824876 & $5 \begin{array}{l}\uparrow \\
\text { CONTROL }\end{array}$ \\
\hline $\begin{array}{l}\text { Immunoglobulin lambda variable } \\
3-25\end{array}$ & LV325 & $1.49 \mathrm{E}-06$ & 7.44370609 & $\begin{array}{l}\uparrow \\
\text { CONTROL }\end{array}$ \\
\hline $\begin{array}{l}\text { Immunoglobulin heavy variable 4- } \\
28\end{array}$ & HV428 & $1.38 \mathrm{E}-06$ & 7.26533223 & $\begin{array}{l}\uparrow \\
\text { CONTROL }\end{array}$ \\
\hline $\begin{array}{l}\text { Immunoglobulin kappa variable } \\
\text { 1D-12 }\end{array}$ & KVD12 & 1.17E-09 & 7.18559345 & $\begin{array}{l}\uparrow \\
\text { CONTROL }\end{array}$ \\
\hline Heparin cofactor 2 & HEP2 & $2.44 \mathrm{E}-07$ & 7.13401112 & $\begin{array}{l}\uparrow \\
\text { CONTROL }\end{array}$ \\
\hline $\begin{array}{l}\text { Inter-alpha-trypsin inhibitor heavy } \\
\text { chain } \mathrm{H} 4\end{array}$ & ITIH4 & $3.63 \mathrm{E}-08$ & 6.70198308 & $\begin{array}{l}\uparrow \\
\text { CONTROL }\end{array}$ \\
\hline $\begin{array}{l}\text { Immunoglobulin lambda variable } \\
\text { 9-49 }\end{array}$ & LV949 & 0.00017391 & 6.43567288 & $\begin{array}{l}\uparrow \\
\text { CONTROL }\end{array}$ \\
\hline Alpha-1B-glycoprotein & A1BG & 1.70E-09 & 6.00033312 & $\begin{array}{l}\uparrow \\
\text { CONTROL }\end{array}$ \\
\hline Apolipoprotein A-I & APOA1 & $1.65 \mathrm{E}-09$ & 5.16689397 & $\begin{array}{l}\uparrow \\
\text { CONTROL }\end{array}$ \\
\hline $\begin{array}{l}\text { Immunoglobulin lambda variable } \\
3-19\end{array}$ & LV319 & $1.92 \mathrm{E}-08$ & 5.05592895 & $\begin{array}{l}\uparrow \\
\text { CONTRO }\end{array}$ \\
\hline
\end{tabular}


M. del Pilar Chantada-Vázquez, A. C. López, M. G. Vence, S. Vázquez-Estévez, B. Acea-Nebril, D.

G. Calatayud, T. Jardiel, S. B. Bravo and C. Núñez, J. Proteomics, 2020, 212, 103581. DOI:

10.1016/j.jprot.2019.103581

\begin{tabular}{|c|c|c|c|c|}
\hline Protein & $\begin{array}{l}\text { UniProt } \\
\text { ID }\end{array}$ & $p$-value & $\begin{array}{l}\text { Fold } \\
\text { change }\end{array}$ & \\
\hline $\begin{array}{l}\text { Immunoglobulin kappa variable 2- } \\
29\end{array}$ & KV229 & $2.59 \mathrm{E}-07$ & 5.02231162 & $\begin{array}{l}\uparrow \\
\text { CONTROL }\end{array}$ \\
\hline $\begin{array}{l}\text { Immunoglobulin heavy variable 6- } \\
1\end{array}$ & HV601 & 2.19E-05 & 4.85408469 & $\begin{array}{l}\uparrow \\
\text { CONTROL }\end{array}$ \\
\hline $\begin{array}{l}\text { Immunoglobulin heavy variable 1- } \\
46\end{array}$ & HV146 & $9.86 \mathrm{E}-06$ & 4.84652628 & $\begin{array}{l}\uparrow \\
\text { CONTROL }\end{array}$ \\
\hline $\begin{array}{l}\text { Immunoglobulin heavy variable 3- } \\
23\end{array}$ & HV323 & $1.25 \mathrm{E}-05$ & 4.75302522 & $\begin{array}{l}\uparrow \\
\text { CONTROL }\end{array}$ \\
\hline Cholesteryl ester transfer protein & CETP & $1.22 \mathrm{E}-05$ & 4.64058921 & $\begin{array}{l}\uparrow \\
\text { CONTROL }\end{array}$ \\
\hline Apolipoprotein A-II & APOA2 & $2.16 \mathrm{E}-08$ & 4.62885891 & $\begin{array}{l}\uparrow \\
\text { CONTROL }\end{array}$ \\
\hline Thyroxine-binding globulin & THBG & $1.80 \mathrm{E}-08$ & 4.45994071 & $\begin{array}{l}\uparrow \\
\text { CONTROL }\end{array}$ \\
\hline $\begin{array}{l}\text { Protein Z-dependent protease } \\
\text { inhibitor }\end{array}$ & ZPI & 4.44E-05 & 4.43951224 & $\begin{array}{l}\uparrow \\
\text { CONTROL }\end{array}$ \\
\hline Serum amyloid A-4 protein & SAA4 & $1.38 \mathrm{E}-07$ & 4.39608833 & $\begin{array}{l}\uparrow \\
\text { CONTROL }\end{array}$ \\
\hline $\begin{array}{l}\text { Immunoglobulin heavy variable 1- } \\
69\end{array}$ & HV169 & 0.00058138 & 3 4.33088897 & $\begin{array}{l}\uparrow \\
\text { CONTROL }\end{array}$ \\
\hline $\begin{array}{l}\text { Immunoglobulin kappa variable 1- } \\
9\end{array}$ & KV109 & 3.99E-06 & 4.20727924 & $\begin{array}{l}\uparrow \\
\text { CONTROL }\end{array}$ \\
\hline Gelsolin & GELS & 7.03E-09 & 4.09546999 & $\begin{array}{l}\uparrow \\
\text { CONTROL }\end{array}$ \\
\hline CD44 antigen & CD44 & 0.00233936 & 64.0837648 & $\begin{array}{l}\uparrow \\
\text { CONTROL }\end{array}$ \\
\hline Apolipoprotein C-I & APOC1 & 0.00038806 & 63.66742486 & $\begin{array}{l}\uparrow \\
\text { CONTROL }\end{array}$ \\
\hline Alpha-2-macroglobulin & A2MG & $3.58 \mathrm{E}-09$ & 3.65331919 & $\begin{array}{l}\uparrow \\
\text { CONTROL }\end{array}$ \\
\hline
\end{tabular}


M. del Pilar Chantada-Vázquez, A. C. López, M. G. Vence, S. Vázquez-Estévez, B. Acea-Nebril, D. G. Calatayud, T. Jardiel, S. B. Bravo and C. Núñez, J. Proteomics, 2020, 212, 103581. DOI:

10.1016/j.jprot.2019.103581

\begin{tabular}{|c|c|c|c|c|}
\hline Protein & $\begin{array}{l}\text { UniProt } \\
\text { ID }\end{array}$ & $p$-value & $\begin{array}{l}\text { Fold } \\
\text { change }\end{array}$ & \\
\hline Apolipoprotein D & APOD & $3.95 \mathrm{E}-08$ & 3.53083248 & $\begin{array}{l}\uparrow \\
\text { CONTROL }\end{array}$ \\
\hline Kallistatin & KAIN & $4.78 \mathrm{E}-10$ & 3.48621242 & $\begin{array}{l}\uparrow \\
\text { CONTROL }\end{array}$ \\
\hline $\begin{array}{l}\text { Immunoglobulin kappa variable 1- } \\
5\end{array}$ & KV105 & $8.42 \mathrm{E}-05$ & 3.22054945 & $\begin{array}{l}\uparrow \\
\text { CONTROL }\end{array}$ \\
\hline Leucine-rich alpha-2-glycoprotein & $\mathrm{A} 2 \mathrm{GL}$ & $1.29 \mathrm{E}-08$ & 3.00855446 & $\begin{array}{l}\uparrow \\
\text { CONTROL }\end{array}$ \\
\hline Hemoglobin subunit beta & HBB & $8.64 \mathrm{E}-05$ & 2.890312 & $\begin{array}{l}\uparrow \\
\text { CONTROL }\end{array}$ \\
\hline $\begin{array}{l}\text { Coiled-coil domain-containing } \\
\text { protein } 8\end{array}$ & CCDC8 & $6.16 \mathrm{E}-07$ & 2.88193259 & $\begin{array}{l}\uparrow \\
\text { CONTROL }\end{array}$ \\
\hline $\begin{array}{l}\text { Immunoglobulin kappa variable } \\
\text { 2D-28 }\end{array}$ & KVD28 & 0.00104876 & 2.6282284 & $\begin{array}{l}\uparrow \\
\text { CONTROL }\end{array}$ \\
\hline $\begin{array}{l}\text { Immunoglobulin kappa variable } \\
\text { 6D-21 }\end{array}$ & KVD21 & 0.01695916 & 2.61227937 & $\begin{array}{l}\uparrow \\
\text { CONTROL }\end{array}$ \\
\hline $\begin{array}{l}\text { Immunoglobulin lambda variable } \\
\text { 4-69 }\end{array}$ & LV469 & $8.14 \mathrm{E}-05$ & 2.35130225 & $\begin{array}{l}\uparrow \\
\text { CONTROL }\end{array}$ \\
\hline Biotinidase & BTD & 0.00622085 & 2.19095666 & $5 \begin{array}{l}\uparrow \\
\text { CONTROL }\end{array}$ \\
\hline Plasma serine protease inhibitor & IPSP & 3.04E-05 & 2.1835559 & $\begin{array}{l}\uparrow \\
\text { CONTROL }\end{array}$ \\
\hline Carboxypeptidase B2 & CBPB2 & $8.55 \mathrm{E}-05$ & 1.8115321 & $\begin{array}{l}\uparrow \\
\text { CONTROL }\end{array}$ \\
\hline $\begin{array}{l}\text { Immunoglobulin heavy variable } 2 \text { - } \\
26\end{array}$ & HV226 & 0.00977698 & 1.69947422 & $\begin{array}{l}\uparrow \\
\text { CONTROL }\end{array}$ \\
\hline Apolipoprotein B-100 & APOB & $2.35 \mathrm{E}-05$ & 1.66025805 & $\begin{array}{l}\uparrow \\
\text { CONTROL }\end{array}$ \\
\hline Alpha-2-antiplasmin & A2AP & 0.00014843 & 1.60147275 & $\begin{array}{l}\uparrow \\
\text { CONTRO }\end{array}$ \\
\hline
\end{tabular}


M. del Pilar Chantada-Vázquez, A. C. López, M. G. Vence, S. Vázquez-Estévez, B. Acea-Nebril, D. G. Calatayud, T. Jardiel, S. B. Bravo and C. Núñez, J. Proteomics, 2020, 212, 103581. DOI:

10.1016/j.jprot.2019.103581

\begin{tabular}{|c|c|c|c|}
\hline Protein & $\begin{array}{l}\text { UniProt } \\
\text { ID }\end{array}$ & $p$-value & $\begin{array}{l}\text { Fold } \\
\text { change }\end{array}$ \\
\hline Apolipoprotein C-III & АРOC3 & 0.0214407 & 51.39259865 \\
\hline
\end{tabular}

In the protein corona formed around the MNPs $(9.30 \pm 0.67 \mathrm{~nm})$, a total of 176 nonredundant proteins were quantified, out of which 57 were found to be differentially regulated. 45 proteins had elevated expression, while 12 proteins showed downregulation (see Table 8).

Table 8. Significant proteins ( $p$-value $<0.05$ ) in comparisons between triple negative breast cancer and controls after the analysis of the protein corona of MNPs $(9.30 \pm 0.67 \mathrm{~nm})$.

\begin{tabular}{|c|c|c|c|c|c|}
\hline & Protein & $\begin{array}{l}\text { UniProt } \\
\text { ID }\end{array}$ & $p$-value & Fold change & \\
\hline & C-reactive protein & CRP & 0.00169149 & 3.40849571 & $\uparrow T N B C$ \\
\hline & $\begin{array}{l}\text { Lipopolysaccharide-binding } \\
\text { protein }\end{array}$ & LBP & 0.00837847 & 72.93851762 & 个 TNBC \\
\hline & $\begin{array}{l}\text { Immunoglobulin kappa variable 2- } \\
24\end{array}$ & KV224 & 0.00583062 & 2.27733934 & 个 TNBC \\
\hline & Serum amyloid P-component & SAMP & 0.00010388 & 2.20872021 & 个 TNBC \\
\hline & $\begin{array}{l}\text { Keratin. type II cytoskeletal } 2 \\
\text { epidermal }\end{array}$ & $\mathrm{K} 22 \mathrm{E}$ & 0.01682722 & 2.10615702 & 个 TNBC \\
\hline & Complement C4-B & CO4B & 0.04180946 & 51.9800469 & $\uparrow T N B C$ \\
\hline its & vs. Complement component C9 & CO9 & 5.75E-06 & 1.90848624 & $\uparrow T N B C$ \\
\hline & IgGFc-binding protein & FCGBP & 0.01481938 & 3 1.86546782 & 个 TNBC \\
\hline & $\begin{array}{l}\text { Protein Z-dependent protease } \\
\text { inhibitor }\end{array}$ & ZPI & 0.00252121 & 11.78800298 & 个 TNBC \\
\hline & $\begin{array}{l}\text { Complement C1q subcomponent } \\
\text { subunit B }\end{array}$ & C1QB & 0.00199072 & 1.78457812 & $\uparrow T N B C$ \\
\hline & $\begin{array}{l}\text { Phosphatidylinositol-glycan- } \\
\text { specific phospholipase D }\end{array}$ & PHLD & 0.00435099 & Э 1.73844701 & 个 TNBC \\
\hline & Prothrombin & THRB & 0.00750791 & 11.72802617 & $\uparrow T N B C$ \\
\hline & Complement C4-A & CO4A & 0.00510952 & 21.67059345 & 个 TNB \\
\hline
\end{tabular}


M. del Pilar Chantada-Vázquez, A. C. López, M. G. Vence, S. Vázquez-Estévez, B. Acea-Nebril, D. G. Calatayud, T. Jardiel, S. B. Bravo and C. Núñez, J. Proteomics, 2020, 212, 103581. DOI:

10.1016/j.jprot.2019.103581

\section{Protein}

Alpha-1-acid glycoprotein 1

Apolipoprotein C-III

Keratin. type II cytoskeletal 1

Sex hormone-binding globulin

Inter-alpha-trypsin inhibito

heavy chain $\mathrm{H} 3$

Complement C3

Keratin. type I cytoskeletal 10

C4b-binding protein alpha chain

Complement factor $\mathrm{H}$

Plasma serine protease inhibitor

Histidine-rich glycoprotein

Complement factor B

Pregnancy zone protein

Complement $\mathrm{C} 1 \mathrm{q}$ subcomponent subunit $A$

Coagulation factor $\mathrm{V}$

Complement factor I

Complement C2

Hemopexin

Coagulation factor XIII B chain

Complement C1q subcomponent subunit $C$

Kininogen-1

Beta-2-glycoprotein 1

Apolipoprotein L1

\section{UniProt \\ ID}

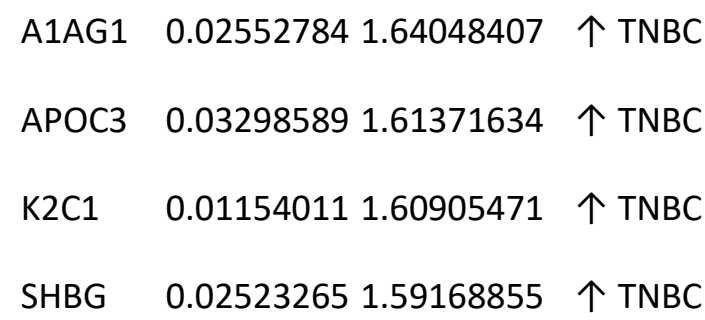

ITIH3 0.000669331 .55061894 个 TNBC

CO3 6.41E-06 1.53090904 个 TNBC

K1C10 $0.0384444 \quad 1.52567319$ 个 TNBC

C4BPA 0.000276051 .51193215 个 TNBC

CFAH $\quad 2.79 E-05 \quad 1.46546396$ 个 TNBC

IPSP $\quad 0.009732551 .4623027 \quad \uparrow$ TNBC

HRG $\quad 0.011644281 .4616738 \quad \uparrow$ TNBC

CFAB $\quad 0.000619031 .45925143 \quad \uparrow$ TNBC

PZP $\quad 0.001552291 .44791482$ 个 TNBC

C1QA $0.027637021 .4062295 \quad \uparrow$ TNBC

FA5 0.013129311 .40131004 个 TNBC

CFAl $\quad 7.52 \mathrm{E}-05 \quad 1.40080904$ 个 TNBC

CO2 0.000613861 .33762187 个 TNBC

HEMO $3.66 \mathrm{E}-05 \quad 1.29733733$ 个 TNBC

F13B $\quad 0.012568431 .28491873$ 个 TNBC

C1QC $\quad 0.037802471 .26491165$ 个 TNBC

KNG1 0.004298481 .26291248 个 TNBC

APOH $\quad 0.047466081 .24963502$ 个 TNBC

APOL1 0.002379441 .23613552 个 TNBC 
M. del Pilar Chantada-Vázquez, A. C. López, M. G. Vence, S. Vázquez-Estévez, B. Acea-Nebril, D.

G. Calatayud, T. Jardiel, S. B. Bravo and C. Núñez, J. Proteomics, 2020, 212, 103581. DOI:

10.1016/j.jprot.2019.103581

\begin{tabular}{|c|c|c|c|c|}
\hline Protein & $\begin{array}{l}\text { UniProt } \\
\text { ID }\end{array}$ & $p$-value & Fold change & \\
\hline Antithrombin-III & ANT3 & 0.01869897 & 1.22888805 & $\uparrow \mathrm{TNBC}$ \\
\hline rotein AMBP & AMBP & 0.01434176 & 1.22857819 & 个 TNBC \\
\hline /itronectin & VTNC & 0.01666796 & 1.21690616 & 个 TNBC \\
\hline $\begin{array}{l}\text { Inter-alpha-trypsin inhibitor } \\
\text { heavy chain } \mathrm{H} 1\end{array}$ & ITIH1 & 0.01847152 & 1.20880937 & 个 TNBC \\
\hline $\begin{array}{l}\text { Insulin-like growth factor-binding } \\
\text { protein complex acid labile } \\
\text { subunit }\end{array}$ & ALS & 0.03555036 & 1.20445695 & 个 TNBC \\
\hline Hyaluronan-binding protein 2 & HABP2 & 0.01352977 & 1.18411135 & 个 TNBC \\
\hline Clusterin & CLUS & 0.04346683 & 1.1756767 & $\uparrow \mathrm{TNBC}$ \\
\hline Alpha-2-HS-glycoprotein & FETUA & 0.02891723 & 1.16730605 & 个 TNBC \\
\hline Galectin-3-binding protein & LG3BP & 0.00292722 & 1.116735 & $\uparrow \mathrm{TNBC}$ \\
\hline Apolipoprotein C-I & APOC1 & 0.02222358 & 2.50213212 & $\begin{array}{l}\uparrow \\
\text { CONTROL }\end{array}$ \\
\hline $\begin{array}{l}\text { Immunoglobulin heavy constant } \\
\mathrm{mu}\end{array}$ & IGHM & 0.00022527 & 2.032717896 & $\begin{array}{l}\uparrow \\
\text { CONTROL }\end{array}$ \\
\hline $\begin{array}{l}\text { Immunoglobulin lambda variable } \\
8-61\end{array}$ & LV861 & 0.00063688 & 2.023228572 & $\begin{array}{l}\uparrow \\
\text { CONTROL }\end{array}$ \\
\hline $\begin{array}{l}\text { Immunoglobulin lambda variable } \\
\text { 3-19 }\end{array}$ & LV319 & 0.0082843 & 1.73294072 & $\begin{array}{l}\uparrow \\
\text { CONTROL }\end{array}$ \\
\hline CD5 antigen-like & CD5L & 0.02066785 & 1.731935965 & $\begin{array}{l}\uparrow \\
\text { CONTROL }\end{array}$ \\
\hline $\begin{array}{l}\text { Immunoglobulin lambda variable } \\
3-9\end{array}$ & LV39 & 0.02497423 & 1.576244295 & $\begin{array}{l}\uparrow \\
\text { CONTROL }\end{array}$ \\
\hline Apolipoprotein F & APOF & 0.02131359 & 1.556435198 & $\begin{array}{l}\uparrow \\
\text { CONTROL }\end{array}$ \\
\hline $\begin{array}{l}\text { Immunoglobulin kappa variable 6- } \\
21\end{array}$ & KV621 & 0.00608326 & 1.473240834 & $\begin{array}{l}\uparrow \\
\text { CONTROL }\end{array}$ \\
\hline $\begin{array}{l}\text { Immunoglobulin heavy variable } 3 \text {. } \\
23\end{array}$ & HV323 & 0.02960462 & 1.38352045 & $\begin{array}{l}\uparrow \\
\text { CONTROL }\end{array}$ \\
\hline
\end{tabular}


M. del Pilar Chantada-Vázquez, A. C. López, M. G. Vence, S. Vázquez-Estévez, B. Acea-Nebril, D.

G. Calatayud, T. Jardiel, S. B. Bravo and C. Núñez, J. Proteomics, 2020, 212, 103581. DOI:

10.1016/j.jprot.2019.103581

\begin{tabular}{|c|c|c|c|c|}
\hline Protein & $\begin{array}{l}\text { UniProt } \\
\text { ID }\end{array}$ & $p$-value & Fold change & \\
\hline $\begin{array}{l}\text { Immunoglobulin heavy variable 4- } \\
28\end{array}$ & HV428 & 0.02327515 & 1.304707447 & $7 \begin{array}{l}\uparrow \\
\text { CONTROL }\end{array}$ \\
\hline Plasma kallikrein & KLKB1 & 0.04204343 & 1.23839695 & $\begin{array}{l}\uparrow \\
\text { CONTROL }\end{array}$ \\
\hline Apolipoprote & APOM & 0.01063485 & 1.232467766 & $6 \stackrel{\uparrow}{\text { CONTRC }}$ \\
\hline
\end{tabular}

A SWATH library was developed. To this aim, the ProteinPilot software (AB Sciex; version 4.0) was used where the proteins were identified with minimum of 2 peptides along with a confidence score above $99 \%$ and FDR below $1 \%$ as threshold criteria. Therefore, a spectral library containing 180 proteins found in the nanoparticle surfaces after serum incubation was employed. In this study, it was shown that this strategy provided a more comprehensive and reproducible coverage of the proteins that can join the different nanoparticle surfaces.

We fixed the cut off to considerate a deregulated protein at $\geq 1.5$ for up-regulation and $\leq 0.67$ for down-regulation. Only proteins with a $p$-value $\leq 0.05$ were selected.

In the analysis of the protein corona formed around the three nanoparticles (AuNPs, AgNPs, and MNPs), eight common proteins showed to be statistically significant and appeared quantitatively increased (up-regulated) in triple negative breast cancer patients versus controls (healthy people) (Fig. 5). These proteins are complement component C9 (CO9), complement C4-A (CO4A), complement C3 (CO3), vitronectin (VTNC), apolipoprotein L1 (APOL1), complement factor H (CFAH), kininogen-1 (KNG1), galectin-3-binding protein (LG3BP). However, three common proteins appeared quantitatively decreased (down-regulated) in triple negative breast cancer patients versus controls (healthy people) (Fig. 6). These proteins are immunoglobulin heavy constant mu (IGHM), immunoglobulin lambda variable 3-9 (LV39) and apolipoprotein C-I (APOC1).

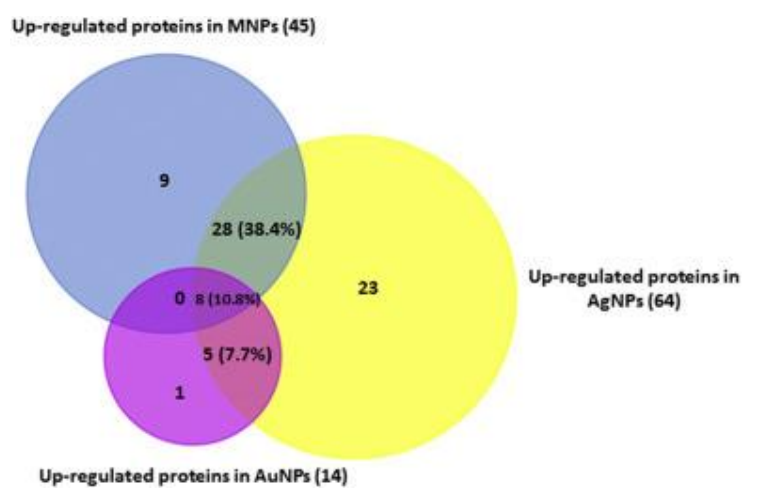

Fig. 5. Quantitative Venn diagrams showing the number of up-regulated proteins found in the protein corona of $10.02 \pm 0.91 \mathrm{~nm}$ gold nanoparticles (AuNPs), $9.73 \pm 1.70 \mathrm{~nm}$ silver nanoparticles (AgNPs) and $9.30 \pm 0.67 \mathrm{~nm}$ magnetic nanoparticles (MNPs) after their incubation with serum from eight triple negative breast cancer patients and eight healthy controls. 
M. del Pilar Chantada-Vázquez, A. C. López, M. G. Vence, S. Vázquez-Estévez, B. Acea-Nebril, D.

G. Calatayud, T. Jardiel, S. B. Bravo and C. Núñez, J. Proteomics, 2020, 212, 103581. DOI:

10.1016/j.jprot.2019.103581

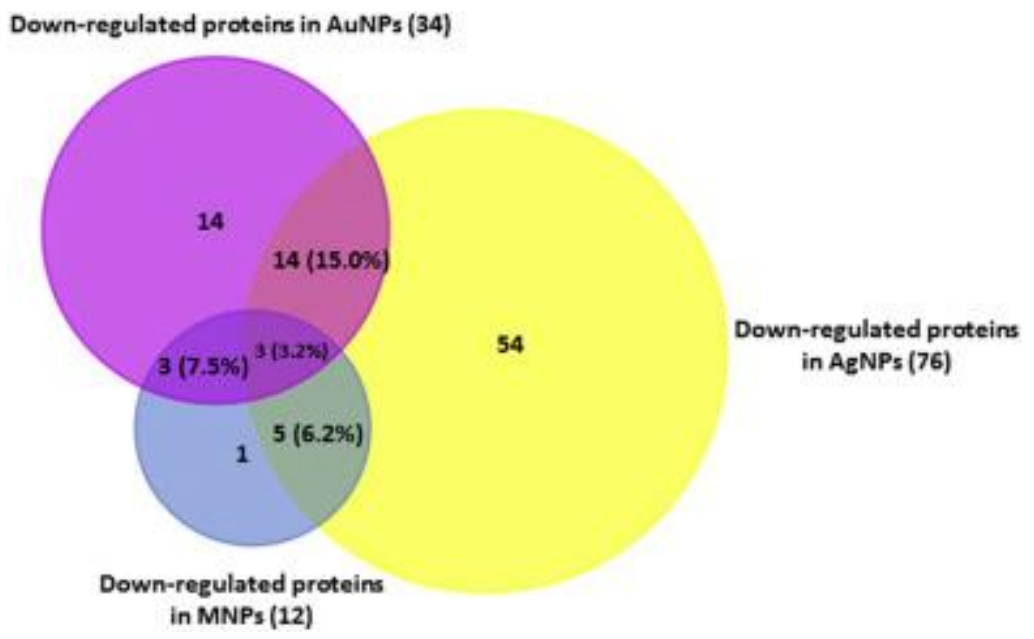

Fig. 6. Quantitative Venn diagrams showing the number of down-regulated proteins found in the protein corona of $10.02 \pm 0.91 \mathrm{~nm}$ gold nanoparticles (AuNPs), $9.73 \pm 1.70 \mathrm{~nm}$ silver nanoparticles (AgNPs) and $9.30 \pm 0.67 \mathrm{~nm}$ magnetic nanoparticles (MNPs) after their incubation with serum from eight triple negative breast cancer patients and eight healthy controls.

After the analysis of the protein corona formed around AuNPs (10.02 $\pm 0.91 \mathrm{~nm}), \operatorname{AgNPs}$ $(9.73 \pm 1.70 \mathrm{~nm})$ and MNPs $(9.30 \pm 0.67 \mathrm{~nm})$, the principal components analysis (PCA) clearly revealed that the samples of the triple negative breast cancer patients and healthy people were separated in the PC1 axis, which explains 47.7, 80.9 and $79.6 \%$ of the variance between the samples, respectively (Figs. S13-S15).

In all cases (AuNPs, AgNPs, MNPs), the separation between the groups of samples is visible between the group of healthy people and the group of triple negative breast cancer.

\subsection{TNBC biomarker validation}

Mass spectrometry-based validation assays were performed in a different cohort of total serum patients samples $(n=8)$ and controls $(n=8)$ which were run in triplicate using a TripleTOF® 6600 LC-MS/MS system (Sciex). A correct protein validation was performed. To this aim, the library was improved after the addition of DDA data acquired from total serum pools (controls and patient), obtaining a total of 205 identified proteins. After comparing the results obtained by this analysis, with previous analysis performed on serum samples after the incubation with the different nanoparticles, fascinating results were observed.

Graphically, these variations can be observed through charts such as the volcano plot. Volcano plots (see Fig. 7) of the global quantification of proteins between healthy and triple negative breast cancer patients with A: AuNPs $(10.02 \pm 0.91 \mathrm{~nm})$, B: AgNPs $(9.73 \pm 1.70 \mathrm{~nm})$ and C: MNPs $(9.30 \pm 0.67 \mathrm{~nm})$ were generated by plotting the $\log 2$-fold changes for the identified proteins against their corresponding adjusted p-value. 
M. del Pilar Chantada-Vázquez, A. C. López, M. G. Vence, S. Vázquez-Estévez, B. Acea-Nebril, D.

G. Calatayud, T. Jardiel, S. B. Bravo and C. Núñez, J. Proteomics, 2020, 212, 103581. DOI:

10.1016/j.jprot.2019.103581

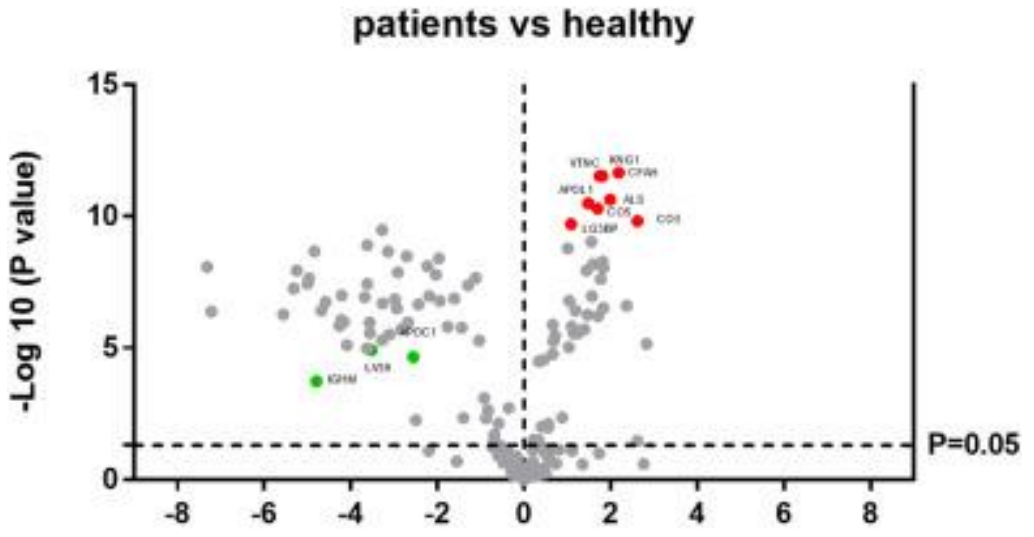

$\log 2$ (fold change)

Fig. 7. Volcano plots of the SWATH analysis of proteins between healthy and triple negative breast cancer patients with AuNPs $(10.02 \pm 0.91 \mathrm{~nm}), \operatorname{AgNPs}(9.73 \pm 1.70 \mathrm{~nm})$ and MNPs $(9.30 \pm 0.67 \mathrm{~nm})$. X-axis shows $\log (2)$-fold change and Y-axis the statistical significance through - $\log (10)$-pvalue. The dot lines represent the cut off ( $\mathrm{p}$ value $\leq 0.05$ ). Proteins biomarkers are those that were common and statistical significative in all the nanoparticles.

Validation assays verified and confirmed that transthyretin (TTHY) was statistically significant and appeared quantitatively decreased (down-regulated) in triple negative breast cancer patients when compared with controls (healthy people). This result was observed after the analysis of the protein corona formed around AuNPs $(10.02 \pm 0.91 \mathrm{~nm})$. A similar observation was recently reported, where it was found that transthyretin (TTHY) was predominantly $(68.75 \%)$ down-regulated $(n=33 / 48)$ in the sera of breast cancer patients [57].

Furthermore, validation assays verified and confirmed that complement component $\mathrm{C} 8$ gamma chain (CO8G), ficolin-3 (FCN3), retinol-binding protein 4 (RET4), fibronectin (FINC), fetuin-B (FETUB) and apolipoprotein A-IV (APOA4), were up-regulated in triple negative breast cancer when compared with controls. However, apolipoprotein CIII (APOC3), immunoglobulin kappa variable 2D-28 (KVD28), immunoglobulin kappa variable 1-5 (KV105), immunoglobulin kappa variable 4-1 (KV401), immunoglobulin kappa variable 1D-12 (KVD12), immunoglobulin heavy variable 1-46 (HV146), immunoglobulin heavy variable 3-30-5 (HV335), immunoglobulin heavy constant gamma 2 (IGHG2), immunoglobulin heavy constant gamma 3 (IGHG3), and immunoglobulin heavy constant gamma 4 (IGHG4) were down-regulated in triple negative breast cancer when compared with controls. These results were observed after the analysis of the protein corona formed around AgNPs $(9.73 \pm 1.70 \mathrm{~nm})$.

Recently, similar studies found that elevated serum levels of retinol binding protein 4 (RBP4) [58] and fibronectin (FINC) [59] were associated with breast cancer risk and they could be useful markers for predicting poor prognosis in breast cancer patients.

In the particular case of apolipoprotein A-IV (APOA4), comparative proteomic profiling of immunodepleted plasma of healthy and of $\mathrm{BC}$ individuals revealed that this protein was also up-regulated in the plasma of the BC individuals. Furthermore, this protein was 
M. del Pilar Chantada-Vázquez, A. C. López, M. G. Vence, S. Vázquez-Estévez, B. Acea-Nebril, D. G. Calatayud, T. Jardiel, S. B. Bravo and C. Núñez, J. Proteomics, 2020, 212, 103581. DOI:

10.1016/j.jprot.2019.103581

found to be involved in the pathogenesis of cancer and played an important role in the regulation of metastasis [무].

Validation assays verified and confirmed that pregnancy zone protein (PZP), coagulation factor V (FA5), protein Z-dependent protease inhibitor (ZPI), alpha-1-acid glycoprotein 1 (A1AG1) and inter-alpha-trypsin inhibitor heavy chain H1 (ITIH1), were statistically significant and appeared quantitatively up-regulated in triple negative breast cancer patients when compared with controls (healthy people). This result was observed after the analysis of the protein corona formed around MNPs $(9.30 \pm 0.67 \mathrm{~nm})$.

Mainly, the pregnancy zone protein (PZP) was found to be implicated the pathogenesis of breast cancer [61].

It is well known that cancer is associated with hypercoagulability, and circumstantial evidence suggests that tumor-expressed coagulation factors actively support cancer pathogenesis and progression. Notably, single nucleotide polymorphisms (SNPs) in F5, encoding coagulation factor V (FA5), have been found associated with breast cancer. In 2018, M. Tinholt et al. [62] found that FA5 expression was higher in breast tumors compared to normal tissue. Importantly, FA5 expression was significantly increased in patients with tumors of aggressive nature (hormone receptor negative-, triple negative-, HER2 enriched-, and basal-like tumors). These authors also suggested that tumorexpressed FA5 could be a possible marker of aggressive breast cancer, and it could emerge as a promising tumor suppressor candidate.

Finally, protein Z-dependent protease inhibitor (ZPI) were identified by immunochemistry in breast cancer cells, whereas they were absent from normal breast tissue [63], and alpha-1-acid glycoprotein (AGP) was also found to be a potential biomarker for breast cancer in 'at risk' individuals, particularly, TNBC patients [64].

\section{Discussion}

In this study, we provided by the first time the application of a combined proteomic approach as DDA and SWATH-MS to develop the characterization and quantification of triple negative breast cancer proteins after bio-corona nanoparticle protein preconcentration.

Gold nanoparticles (AuNPs: $10.02 \pm 0.91 \mathrm{~nm}$ ), silver nanoparticles (AgNPs: $9.73 \pm 1.70 \mathrm{~nm})$ and magnetic nanoparticles (MNPs: $(9.30 \pm 0.67 \mathrm{~nm})$ were assessed in biomarker discovery as a tool for the pre-concentration and separation of proteins from complex proteomes. To this end, sera from eight healthy individuals were compared with sera from eight patients diagnosed with triple negative breast cancer. The application of these nanomaterials, combined with mass spectrometry, has allowed the identification of seven potential biomarkers for the diagnostic and control of TNBC progression: GRFtype zinc finger domain-containing protein 1 (protein ZGRF1), Matrix metalloproteinase9 (MMP9), Lebercilin and Immunoglobulin lambda variable 3-27 (LV327) and LINE-1 type transposase domain-containing protein 1 (LITD1), structural maintenance of chromosomes protein 6 (SMC6) and short coiled-coil protein (SCOC). 
M. del Pilar Chantada-Vázquez, A. C. López, M. G. Vence, S. Vázquez-Estévez, B. Acea-Nebril, D. G. Calatayud, T. Jardiel, S. B. Bravo and C. Núñez, J. Proteomics, 2020, 212, 103581. DOI:

10.1016/j.jprot.2019.103581

After performing over these samples, a SWATH analysis to quantify the protein changes, the separation between the group of healthy people and the group of triple negative breast cancer patients was observed. Moreover, a lot of deregulated proteins among both groups were observed. However, these proteins are not among the altered proteins find by the qualitative DDA assay. The proteomic methods used in this study are complementary and allow improving characterization studies. The fact that they are complementary and not necessarily identify the same proteins is due to the search methods DDA (qualitative), and IDA (SWATH-quantitative) analysis is different.

So, in the analysis of the protein corona formed around the three nanoparticles (AuNPs, AgNPs, and MNPs), eight common proteins showed to be statistically significant and appeared quantitatively increased (up-regulated) in triple negative breast cancer patients versus controls (healthy people). These proteins are complement component $\mathrm{C} 9$ (CO9), complement C4-A (CO4A), complement C3 (CO3), vitronectin (VTNC), apolipoprotein L1 (APOL1), complement factor $\mathrm{H}(\mathrm{CFAH})$, kininogen-1 (KNG1), galectin-3-binding protein (LG3BP). And three common proteins appeared quantitatively decreased (downregulated) in triple negative breast cancer patients versus controls (healthy people). These proteins are immunoglobulin heavy constant mu (IGHM), immunoglobulin lambda variable 3-9 (LV39), and apolipoprotein C-I (APOC1).

Moreover, a lot of deregulated proteins not common to all samples incubated with the different nanoparticles were found. Therefore, protein corona formed around AuNPs in breast cancer patients showed 14 proteins up-regulated and 34 proteins down-regulated, in comparison with the protein corona formed around AuNPs in healthy people. In the case of the protein corona formed around AgNPs, 64 proteins were found to be upregulated, and 76 proteins down-regulated. Finally, in the protein corona formed around the MNPs, 45 proteins had elevated expression, while 12 proteins showed downregulation. From this point of view, AgNPs seem to be more suitable for a clinical translational purpose, because the analysis of the protein corona formed around these systems allows better differentiation between both groups of study: healthy and diseased individuals.

All these proteins can be considered potential triple negative breast cancer biomarker candidates; however, these proteins were found when serum samples were concentrated using a bio-corona nanoparticle. Thus, it was thought that the best validation could be finding these proteins in total serum samples. To this aim, it was performed a new SWATH-MS analysis improving the library, and it allowed us to find several validated proteins.

When it was compared total serum SWATH with concentrated proteins in AgNPs, we found again complement component C8 (CO8G), ficolin-3 (FCN3), retinol-binding protein 4 (RET4), fibronectin (FINC), fetuin-B (FETUB) and apolipoprotein A-IV (APOA4), up-regulated; and immunoglobulin heavy constant gamma 4 (IGHG4), immunoglobulin kappa variable 2D-28 (KVD28), immunoglobulin kappa variable 1-5 (KV105), apolipoprotein C-III (APOC3), immunoglobulin heavy variable 1-46 (HV146), immunoglobulin heavy constant gamma 2 (IGHG2), immunoglobulin heavy constant gamma 3 (IGHG3), immunoglobulin kappa variable 4-1 (KV401), immunoglobulin kappa variable 1D-12 (KVD12) and immunoglobulin heavy variable 330-5 (HV335), down-regulated. It is consistent with data from previous studies, and these 
M. del Pilar Chantada-Vázquez, A. C. López, M. G. Vence, S. Vázquez-Estévez, B. Acea-Nebril, D. G. Calatayud, T. Jardiel, S. B. Bravo and C. Núñez, J. Proteomics, 2020, 212, 103581. DOI:

10.1016/j.jprot.2019.103581

proteins can be considered validated. In the comparison between total serum SWATH and MNPs only found 5 up-regulated proteins pregnancy zone protein (PZP), coagulation factor V (FA5), protein Z-dependent protease inhibitor (ZPI), alpha-1-acid glycoprotein 1 (A1AG1) and inter-alpha-trypsin inhibitor heavy chain H1 (ITIH1). And finally, in the comparison between total serum SWATH and AuNPs, only one down-regulated protein was validated: transthyretin (TTHY).

This study shows that serum proteomics is a valuable tool that can facilitate comprehensive and systematic identification of the serum proteome under both healthy and disease conditions. Thus, serum proteomics could be used for disease diagnosis and prognosis. In our case, we found several breast cancer-specific markers that can be used in the diagnosis. However, due to we found a lot of differentiated proteins, it is necessary complementary assays to reduce the number of protein biomarkers.

\section{Declaration of competing interest}

The authors declare that they have no conflict of interest.

\section{Acknowledgment}

All authors acknowledge Miguel Servet I Programme (CP16/00139) from the "Instituto de Salud Carlos III" (Plan Estatal de I+D+i 2013-2016 and European Development Regional Fund) of the Spanish Ministry of Science, Innovation and Universities. A. Castro López and M.P. Chantada-Vázquez contributed equally to this work.

\section{Appendix A. Supplementary data}

Download : Download Word document (24MB)

Supplementary material

\section{References}

[1] A. Jemal, F. Bray, M.M. Center, J. Ferlay, E. Ward, D. Forman Global cancer statistics CA Cancer J. Clin., 61 (2) (2011), pp. 69-90

[2] M. Arnedos, C. Bihan, S. Delaloge, F. Andre Triple-negative breast cancer: are we making headway at least? Ther. Adv. Med. Oncol., 4 (4) (2012), pp. 195-210

[3] F.C. Geyer, F. Pareja, B. Weigelt, E. Rakha, I.O. Ellis, S.J. Schnitt, J.S. Reis-Filho The spectrum of triple-negative breast disease, high- and low-grade lesions Am. J. Pathol., 187 (10) (2017), pp. 2139-2151

[4] S. Cleator, W. Heller, R.C. Coombes Triple-negative breast cancer: therapeutic options Lancet Oncol., 8 (3) (2007), pp. 235-244

[5] C. Núñez Blood-based protein biomarkers in breast cancer Clin. Chim. Acta, 490 (2019), pp. 113-127 
M. del Pilar Chantada-Vázquez, A. C. López, M. G. Vence, S. Vázquez-Estévez, B. Acea-Nebril, D. G. Calatayud, T. Jardiel, S. B. Bravo and C. Núñez, J. Proteomics, 2020, 212, 103581. DOI:

10.1016/j.jprot.2019.103581

[6] Y. He, A. Mohamedali, C. Huang, M.S. Baker, E.C. Nice Oncoproteomics: current status and future opportunities Clin. Chim. Acta, 495 (2019), pp. 611-624

[7] M. Wilhelm, J. Schlegl, H. Hahne, A. Moghaddas Gholami, M. Lieberenz, M.M. Savitski, E. Ziegler, L. Butzmann, S. Gessulat, H. Marx, T. Mathieson, S. Lemeer, K. Schnatbaum, U. Reimer, H. Wenschuh, M. Mollenhauer, J. Slotta-Huspenina, J.-H. Boese, M. Bantscheff, A. Gerstmair, F. Faerber, B. Kuster Mass spectrometry-based draft of the human proteome Nature, 509 (2014), pp. 582-587

[8] S. Miah, C.A.S. Banks, M.K. Adams, L. Florens, K.E. Lukong, M.P. Washburn Advancement of mass spectrometry-based proteomics technologies to explore triple negative breast cancer Mol. BioSyst., 13 (1) (2016), pp. 42-55

[9] D.M. Schulz, C. Böllner, G. Thomas, M. Atkinson, I. Esposito, H. Höfler, M. Aubele Identification of differentially expressed proteins in triple-negative breast carcinomas using DIGE and mass spectrometry J. Proteome Res., 8 (7) (2009), pp. 3430-3438

[10] C. Ludwig, L. Gillet, G. Rosenberger, S. Amon, B.C. Collins, R. Aebersold Data-independent acquisition-based SWATH-MS for quantitative proteomics: a tutorial Mol. Syst. Biol., 14 (8) (2018), Article e8126

[11] J.G. Meyer, B. Schilling Clinical applications of quantitative proteomics using targeted and untargeted data-independent acquisition techniques Expert Rev. Proteomics, 14 (5) (2017), pp. 419-429

[12] M. Narasimhan, S. Kannan, A. Chawade, A. Bhattacharjee, R. Govekar Clinical biomarker discovery by SWATH-MS based label-free quantitative proteomics: impact of criteria for identification of differentiators and data normalization method J. Transl. Med., 17 (1) (2019), p. 184

[13] N. Rifai, M.A. Gillette, S.A. Carr Protein biomarker discovery and validation: the long and uncertain path to clinical utility Nat. Biotechnol., 24 (8) (2006), pp. 971-983

[14] R. Millioni, S. Tolin, L. Puricelli, S. Sbrignadello, G.P. Fadini, P. Tessari, G. Arrigoni High abundance proteins depletion vs low abundance proteins enrichment: comparison of methods to reduce the plasma proteome complexity PLoS One, 6 (5) (2011), Article e19603

[15] E. Bellei, S. Bergamini, E. Monari, L.I. Fantoni, A. Cuoghi, T. Ozben, A. Tomasi Highabundance proteins depletion for serum proteomic analysis: concomitant removal of nontargeted proteins Amino Acids, 40 (1) (2011), pp. 145-156

[16] S. Chutipongtanate, S. Chatchen, J. Svasti Plasma prefractionation methods for proteomic analysis and perspectives in clinical applications Proteomics Clin. Appl., 11 (7-8) (2017)

[17] C.P. Albuquerque, M.B. Smolka, S.H. Payne, V. Bafna, J. Eng, H. Zhou A multidimensional chromatography technology for in-depth phosphoproteome analysis Mol. Cell. Proteomics, 7 (7) (2008), pp. 1389-1396

[18] D.-G. Liu, L. Sun Direct isolation of specific RNA-interacting proteins using a novel affinity medium Nucleic Acids Res., 33 (15) (2005), p. e132 
M. del Pilar Chantada-Vázquez, A. C. López, M. G. Vence, S. Vázquez-Estévez, B. Acea-Nebril, D. G. Calatayud, T. Jardiel, S. B. Bravo and C. Núñez, J. Proteomics, 2020, 212, 103581. DOI:

10.1016/j.jprot.2019.103581

[19] P.D. Rakowska, M.G. Ryadnov Nano-enabled biomarker discovery and detection Biomark. Med., 5 (3) (2011), pp. 387-396

[20] N. Phogat, M. Kohl, I. Uddin, A. Jahan Chapter 11 - Interaction of nanoparticles with biomolecules, protein, enzymes, and its applications Hans-Peter Deigner, Matthias Kohl (Eds.), Precision Medicine, Tools and Quantitative Approaches, Academic Press (2018), pp. 253-276

[21] S. Tenzer, D. Docter, S. Rosfa, A. Wlodarski, J. Kuharev, A. Rekik, S.K. Knauer, C. Bantz, T. Nawroth, C. Bier, J. Sirirattanapan, W. Mann, L. Treuel, R. Zellner, M. Maskos, H. Schild, R.H. Stauber Nanoparticle size is a critical physicochemical determinant of the human blood plasma corona: a comprehensive quantitative proteomic analysis ACS Nano, 5 (2011), pp. 7155-7167

[22] M.P. Monopoli, D. Walczyk, A. Campbell, G. Elia, I. Lynch, F.B. Bombelli, K.A. Dawson Physical-chemical aspects of protein corona: relevance to in vitro and in vivo biological impacts of nanoparticles J. Am. Chem. Soc., 133 (2011), pp. 2525-2534

[23] S. Laurent, C. Burtea, C. Thirifays, F. Rezaee, M. Mahmoudi Significance of cell "observer" and protein source in nanobiosciences J. Colloid Interface Sci., 392 (2013), pp. 431-445

[24] M. Mahmoudi, A.M. Abdelmonem, S. Behzadi, J.H. Clement, S. Dutz, M.R. Ejtehadi, R. Hartmann, K. Kantner, U. Linne, P. Maffre, S. Metzler, M.K. Moghadam, C. Pfeiffer, M. Rezaei, P. Ruiz-Lozano, V. Serpooshan, M.A. Shokrgozar, G.U. Nienhaus, W.J. Parak Temperature: the "ignored" factor at the NanoBio interface ACS Nano, 7 (2013), pp. 6555-6562

[25] S. Tenzer, D. Docter, J. Kuharev, A. Musyanovych, V. Fetz, R. Hecht, F. Schlenk, D. Fischer, K. Kiouptsi, C. Reinhardt, K. Landfester, H. Schild, M. Maskos, S.K. Knauer, R.H. Stauber Rapid formation of plasma protein corona critically affects nanoparticle pathophysiology Nat. Nanotechnol., 8 (2013), pp. 772-781

[26] T. Zheng, N. Pierre-Pierre, X. Yan, Q. Huo, A.J. Almodovar, F. Valerio, I. Rivera-Ramirez, E. Griffith, D.D. Decker, S. Chen Gold nanoparticle-enabled blood test for early stage cancer detection and risk assessment ACS Appl. Mater. Interfaces, 7 (12) (2015), pp. 6819-6827

[27] C. Corbo, R. Molinaro, M. Tabatabaei, O.C. Farokhzad, M. Mahmoudi Personalized protein corona on nanoparticles and its clinical implications Biomater. Sci., 5 (3) (2017), pp. 378-387

[28] R. Lopez-Cortés, E. Oliveira, C. Núñez, C. Lodeiro, M. Páez de la Cadena, F. Fdez-Riverola, H. López-Fernández, M. Reboiro-Jato, D. Glez-Peña, J.L. Capelo, H.M. Santos Fast human serum profiling through chemical depletion coupled to gold-nanoparticle-assisted protein separation Talanta, 100 (2012), pp. 239-245

[29] N.G. Bastus, F. Merkoci, J. Piella, V. Puntes Synthesis of highly monodisperse citratestabilized silver nanoparticles of up to $200 \mathrm{~nm}$ : kinetic control and catalytic properties Chem. Mater., 26 (9) (2014), pp. 2836-2846

[30] A.H. Lu, E.L. Salabas, F. Schüth Magnetic nanoparticles: synthesis, protection, functionalization, and application Angew. Chemie-Int. Ed., 46 (2007), pp. 1222-1244

[31] S.E. Warder, L.A. Tucker, T.J. Strelitzer, E.M. McKeegan, J.L. Meuth, P.M. Jung, A. Saraf, B. Singh, J. Lai-Zhang, G. Gagne, J.C. Rogers Reducing agent-mediated precipitation of highabundance plasma proteins Anal. Biochem., 387 (2) (2009), pp. 184-193 
M. del Pilar Chantada-Vázquez, A. C. López, M. G. Vence, S. Vázquez-Estévez, B. Acea-Nebril, D. G. Calatayud, T. Jardiel, S. B. Bravo and C. Núñez, J. Proteomics, 2020, 212, 103581. DOI:

10.1016/j.jprot.2019.103581

[32] C. Fernández, H.M. Santos, C. Ruíz-Romero, F.J. Blanco, J.L. Capelo-Martínez A comparison of depletion versus equalization for reducing high-abundance proteins in human serum Electrophoresis, 32 (21) (2011), pp. 2966-2974

[33] J.R. de Jesus, R. da Silva Fernandes, G. de Souza Pessôa, I.M. Raimundo Jr., M.A.Z. Arruda Depleting high-abundant and enriching low-abundant proteins in human serum: an evaluation of sample preparation methods using magnetic nanoparticle, chemical depletion and immunoaffinity techniques Talanta, 170 (2017), pp. 199-209

[34] M.P. Chantada-Vázquez, A. Castro López, S.B. Bravo, S. Vázquez-Estévez, B. Acea-Nebril, C. Núñez Proteomic analysis of the bio-corona formed on the surface of $(\mathrm{Au}, \mathrm{Ag}, \mathrm{Pt})$ nanoparticles in human serum Colloids Surf. B Biointerfaces, 177 (2019), pp. 141-148

[35] G. Candiano, M. Bruschi, L. Musante, L. Santucci, G.M. Ghiggeri, B. Carnemolla, P. Orecchia, L. Zardi, P.G. Righetti Blue silver: a very sensitive colloidal Coomassie G-250 staining for proteome analysis Electrophoresis, 25 (9) (2004), pp. 1327-1333

[36] E. Oliveira, J.E. Araújo, S. Gómez-Meire, C. Lodeiro, C. Perez-Melon, E. Iglesias-Lamas, A. Otero-Glez, J.L. Capelo, H.M. Santos Proteomics analysis of the peritoneal dialysate effluent reveals the presence of calcium-regulation proteins and acute inflammatory response Clin. Proteomics, 11 (1) (2014), p. 17

[37] I.V. Shilov, S.L. Seymour, A.A. Patel, A. Loboda, W.H. Tang, S.P. Keating, C.L. Hunter, L.M. Nuwaysir, D.A. SchaefferThe paragon algorithm, a next generation search engine that uses sequence temperature values and feature probabilities to identify peptides from tandem mass spectra Mol. Cell. Proteomics, 6 (2007), pp. 1638-1655

[38] W.H. Tang, I.V. Shilov, S.L. Seymour Nonlinear fitting method for determining local false discovery rates from decoy database searches J. Proteome Res., 7 (2008), pp. 3661-3667

[39] I. Ortea, I. Ruiz-Sánchez, R. Cañete, J. Caballero-Villarraso, M.D. Cañete Identification of candidate serum biomarkers of childhood-onset growth hormone deficiency using SWATH-MS and feature selection J. Proteome, 175 (2018), pp. 105-113

[40] H.T. Tan, M.C.M. Chung Label-free quantitative phosphoproteomics reveals regulation of vasodilator-stimulated phosphoprotein upon stathmin-1 silencing in a pair of isogenic colorectal cancer cell lines Proteomics, 18 (8) (2018), Article e1700242

[41] M.A. Dobrovolskaia, A.K. Patri, J. Zheng, J.D. Clogston, N. Ayub, P. Aggarwal, B.W. Neun, J.B. Hall, S.E. McNeil Interaction of colloidal gold nanoparticles with human blood: effects on particle size and analysis of plasma protein binding profiles Nanomedicine, 5 (2009), pp. 106117

[42] R. García-Álvarez, M. Hadjidemetriou, A. Sánchez-Iglesias, L.M. Liz-Marzán, K. Kostarelos In vivo formation of protein corona on gold nanoparticles. The effect of size and shape Nanoscale, 10 (3) (2018), pp. 1256-1264

[43] S.T. Yang, Y. Liu, Y.W. Wang, A. Cao Biosafety and bioapplication of nanomaterials by designing protein-nanoparticle interactions Small, 9 (2013), pp. 1635-1653 
M. del Pilar Chantada-Vázquez, A. C. López, M. G. Vence, S. Vázquez-Estévez, B. Acea-Nebril, D. G. Calatayud, T. Jardiel, S. B. Bravo and C. Núñez, J. Proteomics, 2020, 212, 103581. DOI:

10.1016/j.jprot.2019.103581

[44] J. Chen, Y. Wang, X. Ding, Y. Huang, K. Xu Magnetic solid-phase extraction of proteins based on hydroxy functional ionic liquid-modified magnetic nanoparticles Anal. Methods, 6 (2014), pp. 8358-8367

[45] L. Treuel, D. Docter, M. Maskos, R.H. Stauber, R.H. Stauber Protein corona - from molecular adsorption to physiological complexity Beilstein J. Nanotechnol., 6 (2015), pp. 857-873

[46] M. Cassandri, A. Smirnov, F. Novelli, C. Pitolli, M. Agostini, M. Malewicz, G. Melino, G. Raschellà Zinc-finger proteins in health and disease Cell Death Dis., 3 (2017), p. 17071

[47] J. Jen, Y.-C. Wang Zinc finger proteins in cancer progression J. Biomed. Sci., 23 (2016), p. 53

[48] B.I. Bassey-Archibong, J.M. Kwiecien, S.B. Milosavljevic, R.M. Hallett, L.G. Rayner, M.J. Erb, C.J. Crawford-Brown, K.B. Stephenson, P.A. Bédard, J.A. Hassell, J.M. Daniel Kaiso depletion attenuates transforming growth factor- $\beta$ signaling and metastatic activity of triple-negative breast cancer cells Oncogenesis, 5 (2016), p. e208

[49] E.S. Radisky, D.C. Radisky Matrix metalloproteinases as breast cancer drivers and therapeutic targets Front. Biosci. (Landmark Ed.), 20 (2015), pp. 1144-1163

[50] K. Kessenbrock, V. Plaks, Z. Werb Matrix metalloproteinases: regulators of the tumor microenvironment Cell, 141 (1) (2010), pp. 52-67

[51] E.S. Radisky, D.C. Radisky Matrix metalloproteinase-induced epithelial-mesenchymal transition in breast cancer J. Mammary Gland Biol. Neoplasia, 15 (2) (2010), pp. 201-212

[52] D.P. Nanda, H. Sil, S. Moulik, J. Biswas, S.S. Mandal, A. Chatterjee Matrix metalloproteinase9 as a potential tumor marker in breast cancer J. Environ. Pathol. Toxicol. Oncol., 32 (2) (2013), pp. $115-129$

[53] L.J. van 't Veer, H. Dai, M.J. van de Vijver, Y.D. He, A.A. Hart, M. Mao, H.L. Peterse, K. van der Kooy, M.J. Marton, A.T. Witteveen, G.J. Schreiber, R.M. Kerkhoven, C. Roberts, P.S. Linsley, R. Bernards, S.H. Friend Gene expression profiling predicts clinical outcome of breast cancer Nature, 415 (6871) (2002), pp. 530-536

[54] T.G. Kormelink, D.G. Powe, S.A. Kuijpers, A. Abudukelimu, M.H.A.M. Fens, E.H.E. Pieters, W.W. Kassing-van der Ven, H.O. Habashy, I.O. Ellis, B.R. Blokhuis, M. Thio, W.E. Hennink, G. Storm, F.A. Redegeld, R.M. Schiffelers Immunoglobulin free light chains are biomarkers of poor prognosis in basal-like breast cancer and are potential targets in tumor-associated inflammation Oncotarget, 5 (10) (2014), pp. 3159-3167

[55] S.L. Anwar, W. Wulaningsih, U. Lehmann Transposable elements in human cancer: causes and consequences of deregulation Int. J. Mol. Sci., 18 (5) (2017) pii: E974

[56] C. Behrens, B. Binotti, C. Schmidt, C.V. Robinson, J.J. Chua, K. Kühnel Crystal structure of the human short coiled coil protein and insights into SCOC-FEZ1 complex formation PLOS One, 8 (10) (2013), Article e76355

[57] F.U. Nasim, S. Ejaz, M. Ashraf, A.R. Asif, M. Oellerich, G. Ahmad, G.A. Malik, Attiq-UrRehman Potential biomarkers in the sera of breast cancer patients from Bahawalpur, Pakistan Biomark Cancer, 4 (2012), pp. 19-34 
M. del Pilar Chantada-Vázquez, A. C. López, M. G. Vence, S. Vázquez-Estévez, B. Acea-Nebril, D. G. Calatayud, T. Jardiel, S. B. Bravo and C. Núñez, J. Proteomics, 2020, 212, 103581. DOI:

10.1016/j.jprot.2019.103581

[58] C. Jiao, L. Cui, A. Ma, N. Li, H. Si Elevated serum levels of retinol-binding protein 4 are associated with breast cancer risk: a case-control study PLoS One, 11 (12) (2016), Article e0167498

[59] Y.K. Bae, A. Kim, M.K. Kim, J.E. Choi, S.H. Kang, S.J. Lee Fibronectin expression in carcinoma cells correlates with tumor aggressiveness and poor clinical outcome in patients with invasive breast cancer Hum. Pathol., 44 (2013), pp. 2028-2037

[60] D. Arora, Z. Mahmood, J. George, A.K. Yadav, S. Kumar, U.S. Singh, Y. Shukla Plasma protein profiling of breast cancer patients of North Indian population: a potential approach to early detection J. Proteomics Bioinform., 6 (2013), p. 5

[61] R. Kumar, E. Kuligina, A. Sokolenko, I. Bizin, A.K. Varma, S.K. Hasan Identification of Pregnancy Zone Protein in the Pathogenesis of Breast Cancer (December 2018), 10.13140/RG.2.2.15317.06887

[62] M. Tinholt, Ø. Garred, E. Borgen, E. Beraki, M. Sletten, K. Kleivi Sahlberg, P.M. Sandset, N. Iversen Coagulation factor $\mathbf{V}$ is expressed in tumors and predicts favorable outcome in aggressive breast cancer Thromb. Res., 164 (2018), pp. S183-S184

[63] E. Sierko, M.Z. Wojtukiewicz, K. Ostrowska-Cichocka, L. Zimnoch Protein Z-dependent protease inhibitor (ZPI) is present in loco in human breast cancer tissue Thromb. Haemost., 104 (1) (2010), pp. 183-185

[64] K.D. Smith, J. Behan, G. Matthews-Smith, A.M. Magliocco Alpha-1-acid glycoprotein (AGP) as a potential biomarker for breast cancer Glycosylation (2012), 10.5772/48177 